\title{
تقويم الأداي التدريسي لمعلمي العلوم الشرعية بالمرحلة الثانوية بمحافظة عفيف في ضوء مهارات التدريس التمايز
}

\section{سعر بن نايف بن مخمر العتيبي}

مقلدمة:

$$
\begin{aligned}
& \text { شرفًا أنه يُعلّم الطلاب كتاب الله وسنة رسوله } \\
& \text { محمد }
\end{aligned}
$$

ومع إيمان، وقناعة التربويين بأهميــة

جعل الطالب محور العملية التعليمية، إلا أن

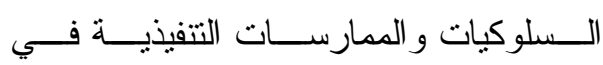
المدرسة، وفي الفصل لا تتفــق مـــع هــذه القناعات تمامًا، ولذلك جاءت نظرية تنويـــع التدريس (التدريس المتمايز) التي تبــدأ مـــع الطالب من حيث هو، أي من حيث استعداده لدر اسة الموضوع المطروح، ومــن حيــث مئث

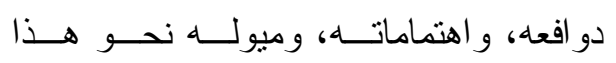
الموضوع، وتزمس عدة مـسـار ات منتوعــة تُمكن كل طالب أن يتخير من بينها المـسـار الذي يتلاءم مع استعداده، وقدر اته، وميوله،

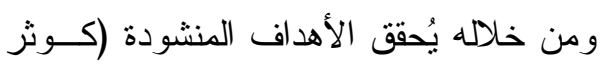

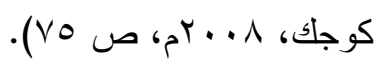

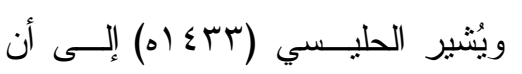

التدريس المتمايز يُحقق العديد من الميـز ات في العملية التعليمية؛ حيث يُسـهم هذا النــوع من التدريس في تأهيل المعلمين لقتح فرص تعلم لجميع طلابهم وذلك بتوفير تجــارب
يثهـ العالم مع بداية الألفيــة الثالثــة

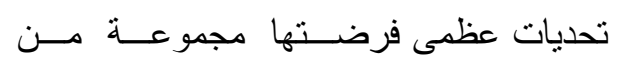
المتغير ات، ويأتي في مقدمة هذه المتغيــر ات

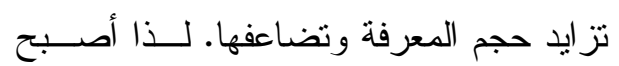
من الضروري أن يو اكب هــــه التـــــيات إصلاحات فـي الميــــان التزبـــوي، حيــث إن التربية هي الأداة التي تبني الفرد القـادر

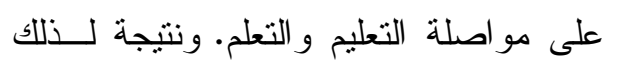
احتل التطوير و الإصـلاح التزبــوي مركــز الــصدارة فــي فكــر التربـــوبين وضــــن أولوياتهم ..

ويرى الزنيــدي (ع أ. إم) أن معلــم العلوم الثرعية يحمل على عاثقــه رســالة عظيمه، فينبغي أن ينظــر إلــى دوره فــي تدريس العلوم الثرعية علـى أنــهـ رســالة كريمه، و أمانه شريفه، وليس وظيفة مقابــلـ

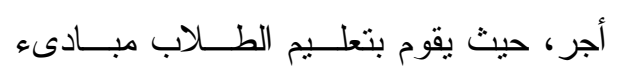
التزبية الإسلامية التي لا تقوم الحياة السعيدة إلا بها، وهو مرشد وموجه ومصلح وداعية

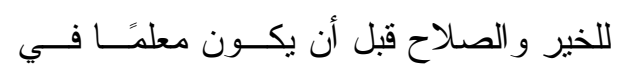
الصف الدر اسي، وكفي معلم العلوم الثرعية 
- ما أكدته الأدبيات التزبوية من أهمية تقويم الأداء التدريسي للمعلم للحصول على المعلومات اللازمة التي تُمكن القائمين على العمل التربوي من اتخاذ القر ارات المناسبة التي تُسهم في نطوير هذا الأداء المعلم وتحسينه بوصفه أحد

المدخلات الأساسية للعملية التعليمية. - ما أكدته نتائج بعض الدراسات السابقة التي أُجريت في بيئات مختلفة، وفي نيات لتعني مستويات تعليمبة مختلفة من فعالية استخدام استراتيجية التدريس المتمايز في تحقيق بعض نواتج العملية التعليمية، ومن هذه الدراسات: دراسة كويزي Koeze

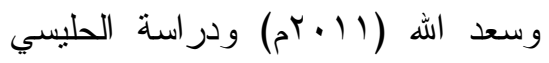

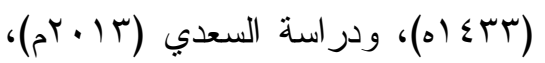

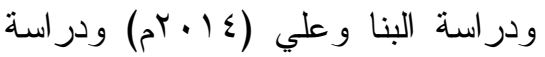

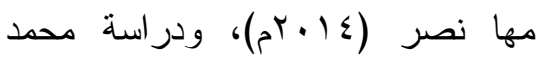

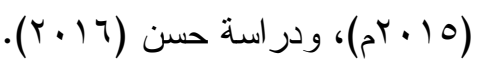
- مشاهدات الباحث في الميدان التربوي؛ حيث لحظ من و اقع عمله معلمًا لمقرر

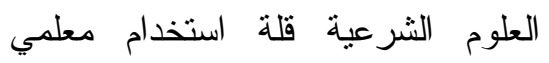
العلوم الثرعية بالمرحلة الثانوية لاستراتيجيات التدريس المتمايز، حيث ما زالت أساليب التدريس التقليدية التي لتئين تعتمد على الإلقاء من جانب المعلم،

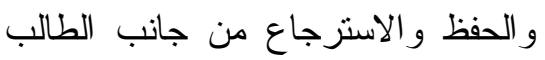

تعلمّم مختلفة، كما يُر اعــي إثتـباع وتتميــة

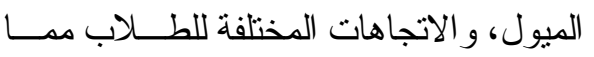
يُعزز مستوى الدافعية ويرفع مستوى التحدي لديهم للتعلم، ويُساعدهم على تتمية الابتكــار ويكثف عما لديهم من إبداعات، بالإضــافة لذلك فإن التدريس المتمايز يقوم على التكامل بين الاستر اتيجيات المختلفة للتعليم من خلد لفي

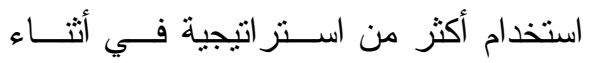
التدريس، كما يُحقق مبدأ التعلم الفعال، ويُلبي لئي منطلبات المنهاج الدر اسي بطريقة ذات معنى ليقي لتحقيق نجاح الطلاب (ص rV). ويؤكد صبري و الر افعي (r . . r م) أن

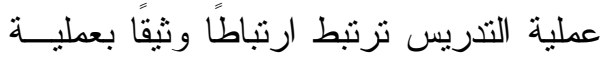

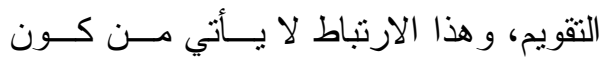

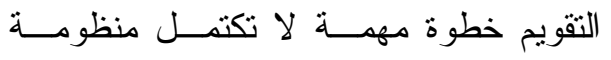
التذريس بدونها فحسب، فالتقويم يُعد عمليـــة

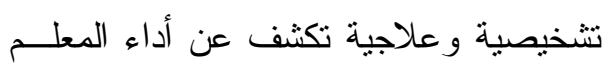

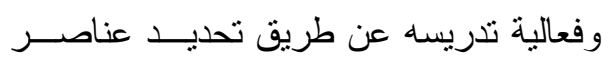

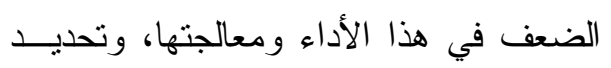

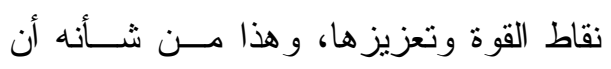

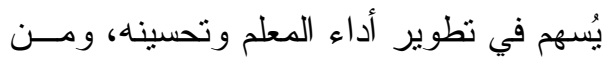
ثم تحقيق الأهداف الرئيسة لعطلية تقويم المعلم

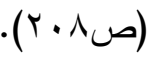

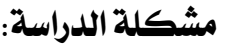

نبـــع إحـــــاس الباحــــث بمــشكلة

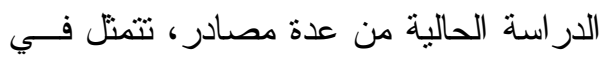

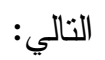


r- ما التصور المقتــرح؛ لتحـسين الأداء

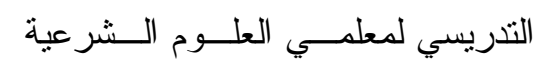

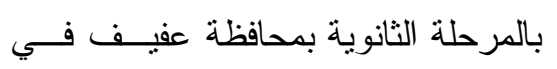
ضوء التدريس المتمايز؟

أهداف الدراسة:

تهدف الدر اسة الحاليـــة إلــى تحقيـــق ما يلي: 1 - إعـــداد قائمـــة بالمهـــار ات التدريـــية

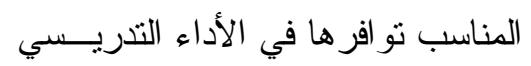

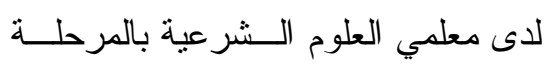

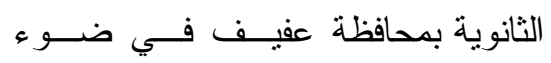

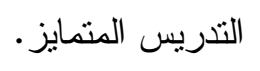

r- التعرف علــى و اقــع الأداء التنريسـسي لمعلمي العلوم الثر عية بالمرحلة الثانوية

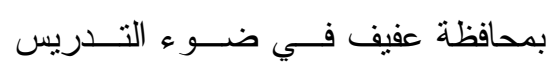

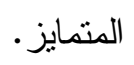

r-وضع تصور مقتــرح؛ لتحسـين الأداء التذريسي لمعلمـي العلــوم الــشرعية

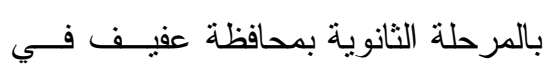
ضوء التدريس المتمايز.

أهمية الدراسة: - الأهمية العلمية:

تتمنل الأهمية النظرية للاراسة الحالية في الآتي: - تقويم الأداء التذريسي لمعلمـي العلــوم الثر عية بالمرحلة الثانوية بوصفه وسيلة

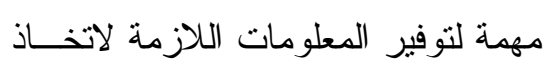

هي السائدة دون مر اعاة لما بين الطلاب

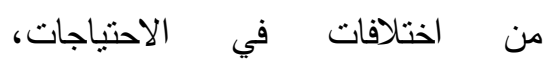
و المعارف السابقة و الذكاءات، و وأنماط التعلم المفضلة لديهر. و على ذلك، شعر الباحث أن اســتخدام استر اتيجية التدريس المتمايز - رغم أهميتها

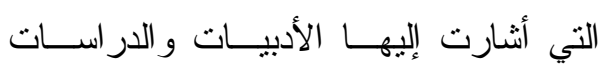
السابقة- في فصول تعليم مقـرر ات العلــوم

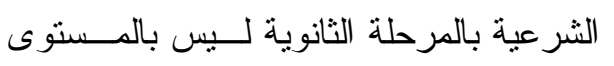

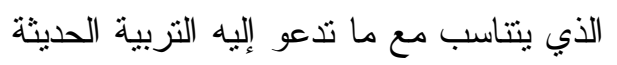
من ضرورة مر اعاة الاختلافات بين الطلاب الثابه لتربيه

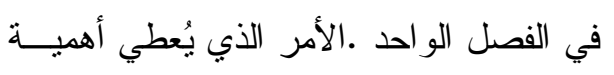
للار اسة الحالية للوقوف على واقــع الأداء

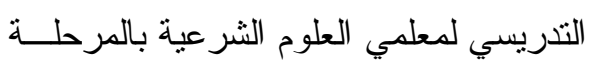
الثانوية في ضو ء مهار ات التدريس المتمايز • أسئلة الدراسة: تسعي الدراسة الحالية إلى الإجابة عن الأسئلة التالية: ا ـ ما المهار ات التدريسية المناسب تو افرها لاى معلمي العلوم الــشر عية بالمرحلـــة

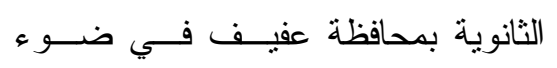

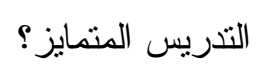

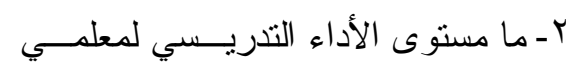

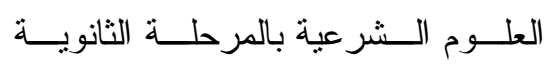

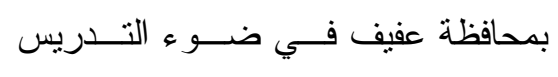
المنمايز ؟ بافطه 
في ضوء التدريس المتمايز ، ووضع تصور مقترح؛ لتحسين الأداء التدريسي لمعلمي العلوم الثرعية بالمرحلة الثانوية بمحافظة عفيف في ضوء التنريس المتمايز •

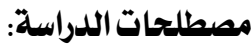
1- تقويم

Performance Teaching Evalution

ويُعرف الباحث تقويم الأداء التدريسي

إجر ائيًا بأنه: الحكم على مستوى امتلالك معلم

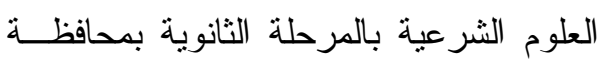

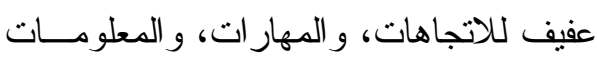

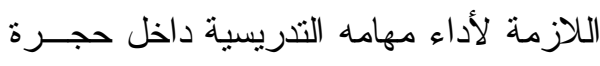
الدراسة لتحقيق أهداف درس محدد، ويستـل لادل

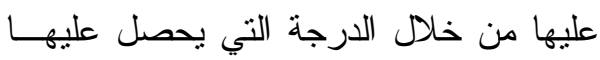
المعلم في بطاقة الملاحظة، وبطاقة المقابلـــة

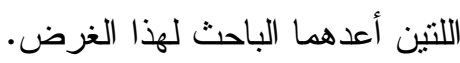

Performance : الأداء التّريسي

\section{Teaching}

ويُعـرف الباحـــث الأداء التذريـسـي

للمعلم إجرائًا بأنه: جميع الممارسات التـي

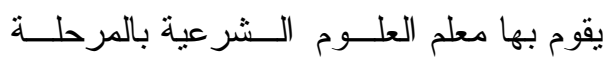
الثانوية في غرفة الدر اسة في ضوء التدريس

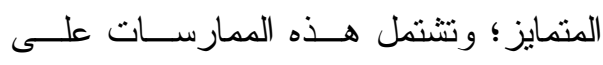

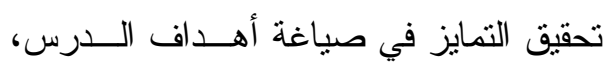

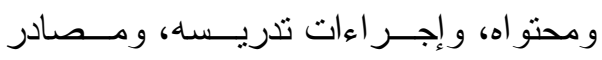

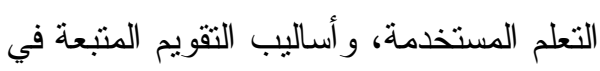
تقويم جو انب التعلم لدى الطلاب.

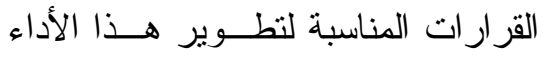

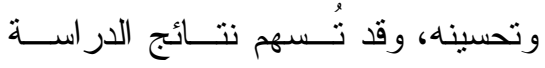

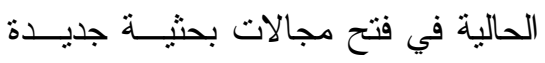

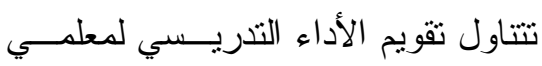

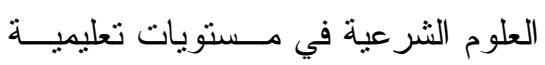

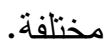

r - الأهمية العملية:

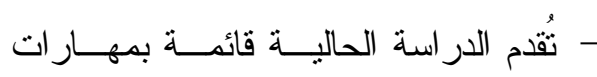

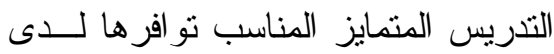

معلم العلوم الثرعية بالمرحلة الثانويــة،

مما يُعينه على ممارسة هذه المهارت في

القاعة الصفية.

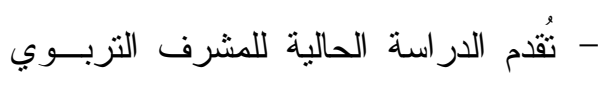

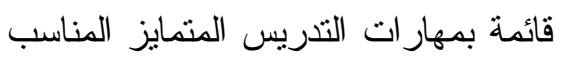

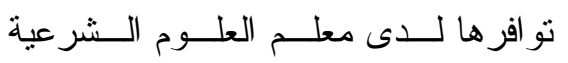

بالمرحلة الثانوية.

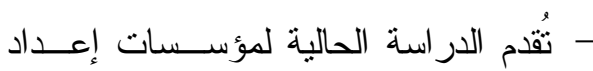

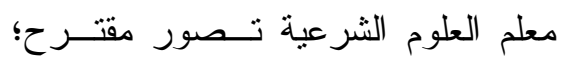

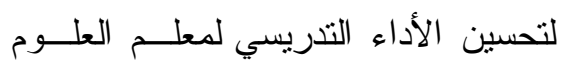

الثرعية في ضوء التنريس المتمايز •

حدود الدراسة:

اقتصرت الحدود الموضوعية في هذه

الدراسة على قائمة الدهارات التدريسية المناسب تو افر ها لاى معلمي العلوم الثرعية بالمرحلة الثنانوية في ضوء التدريس المتمايز ، ودر اسة واقع الأداء التدريسي لمعلمي العلوم الثرعية بالمرحلة الثانوية بمحافظة عفيف لادرديف 
ب- أسس تقويم الأداء التدريسي

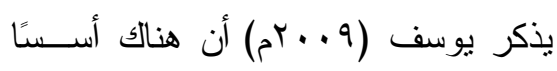

مهمة يجب أن ترتكز عليها عمليــة تقــويم

الأداء التدريسي للمعلم، تتضمن ما يلي:

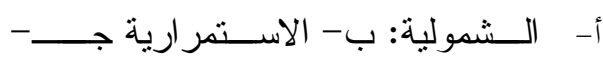

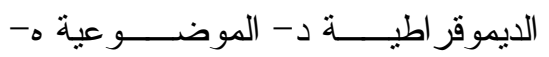

$$
\text { الصدق (Av). }
$$

و على ذللك، يؤكد الباحث على أهميــة

أن يستند تقويم الأداء التدريسي لمعلم العلوم

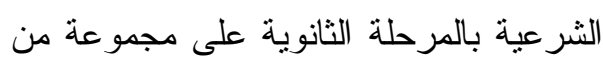
القو اعد أو الأسس الرئيسة، والتي من بينهــــا

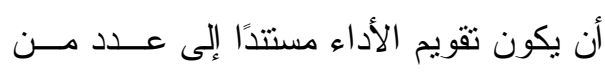

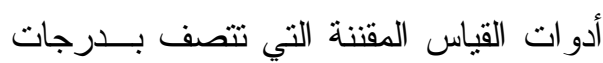

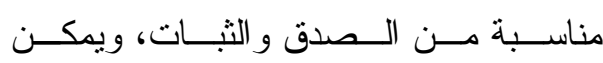
استخدامها على نحو موضو عي فـــي الحكـم ونـ على الأداء.

ج- أهداف تقويم الأداء التدريسي

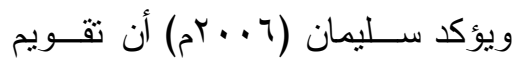

الأداء التدريسي للمعلم تحديدًا يجب أن يهدف إلى تحقيق التالي:

تحسين المهار ات و الكفـــاءات العلميــة و التربوية الخاصة بفن التدريس. " تعزيــز الحــصول علـــى الخبـــرات التذريسية. تطوير الأنشطة الصفية واللاصفية. r- Differentiated التدريس المتمــايز

Teaching

ويُعرفه الباحث التــدريس المتمــايز

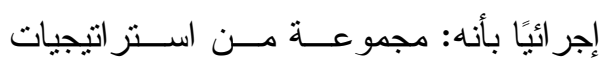

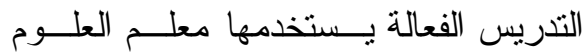
الثر عية بالمرحلة الثانوية في تدريسه للطلاب

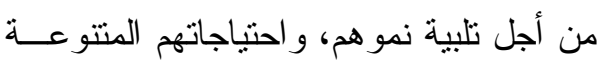

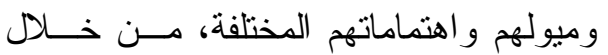
ممايزة الأهداف، و المحتوى، و الإجــر اءات، ولهُ ومصادر التعلم و التقويم. أولًا: الإطار النظري أ- مفهوم الأداء التدريسي التصني تعددت مفاهيم التربوبين حــول الأداء التدريسي بتعدد آر ائهم، ووجهــــات نظــــرهم

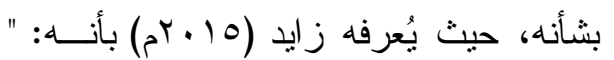
عملية تربوية هادفة تختبــر درجــة كفــاءة التنريس، بناء على مواصفات ومعايير كمية تمهيدًا لتقويم هذه الكفاية، و الحكم على قيمتها

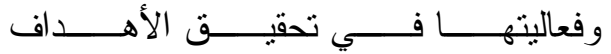
الوطنية/التزبوية المرجوة"(صبr). يـرى الباحسـث أن الأداء التنريسـسي

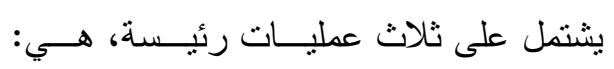
التخطيط للتندريس، تتفيذ التــدريس (تهيئــة الطلاب، استخدام طر ائق التدريس، تــصميح الأنشطة التعليمية، اختيار الوسائط التعليمية، توفير التعزيز المناســب للطــلاب) تقــــيم التدريس. 
وخارجها، فضلًا عن نوفير المعلومات الدقيقة التي يمكن في ضوئها تحسين بر امج إعــداد

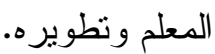
د - طرق تقويــــم الأداء التدريسي

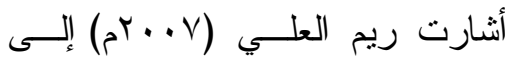
مجموعة من الأساليب و الطرق التي تستخدم

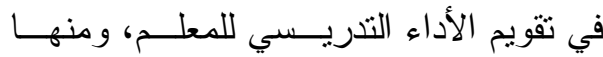

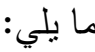

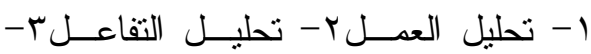
ملاحظة المعلم

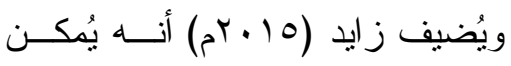
استخدام أحد نمطين لتقويم الأداء التدريسي،

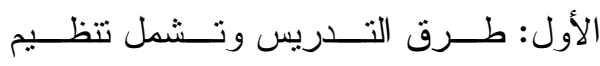

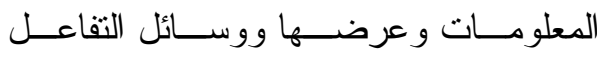

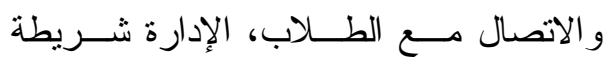

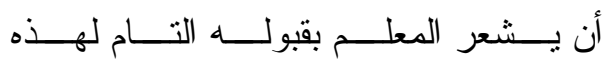

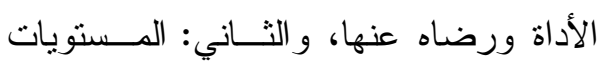
المهنية: مثل الأنشطة الصفية، و المسؤوليات

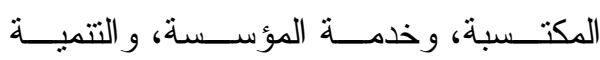

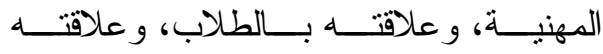

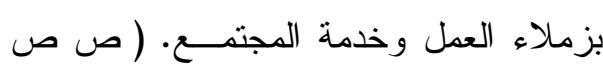
(بر)

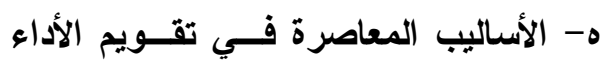
التدريسي من بين هذه الأساليب ما يلي: (يوسف،

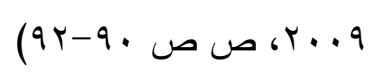

تحسين قـدرة المعلــم علــى الــتحكم

والاستتمار الأمثل للوقت المحدد.(صَّ)

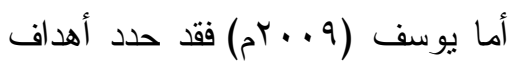
تقويم الأداء التذريسي للمعلم في التالي: • تحقيق أهداف برنامج التتميــة المهنيـــة للمعلمين.

إبر از خصائص التقويم التربوي الجديد. النو ازن بين الجوانب العملية و الجوانب

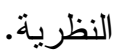

التأكيد على اكتساب المعلــــم للمهــــار ات التالية: - المهــار ات الأدائيــة داخــل حجـــــة

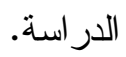
- المهار ات اللغوية اللازمــة لتخــصص المعلم. - المهار ات اللازمة لتدريس المادة.

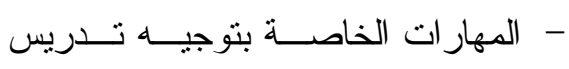
مختلف المواد في إطـــار الاتجاهــات

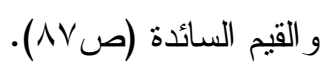

و على ذللك، يرى الباحث إن لتقــــيم

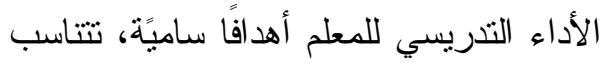

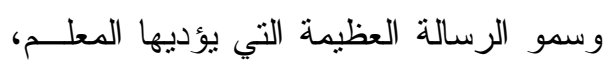
ومن أهمها مساعدة المعلم على تطوير ذاته،

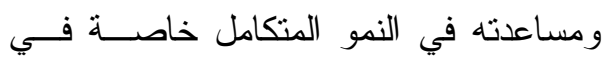
النو احي المهنية و العلمية و الذاتية، وتحسـسين

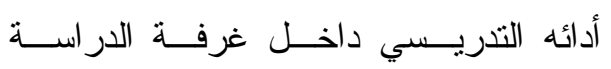


التدريسي للمعلم، كما ينبغي أن تشتمل هـــه الملفات على معيارين أساسيين: المعيار الأول: الإنجاز ات التعليمية المعيار الثاني: الانطباعات الثخصية

يرى الباحث أن تحقيق الجــودة فــي التعليم يتطلب وجود معلم كفء. فلم يعد دور المعلم نزويد الطلاب بالمعلومات فقط، و إنما أصبح دوره تحقيق النمو الثامل و التكامل في شخصية الطالب، و لابد من اعتماد أســاليب

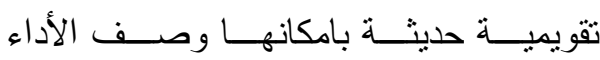
التدريسي للمعلم وصفا كميًا ونوعيًا يسهم في وحئ

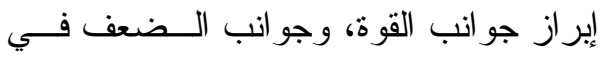

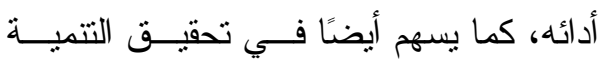
المهنية المستمرة له. له. و - مشكلات تقويم الأداء التّريسي إن تقويم الأداء التدريسي للمعلم يو اجه

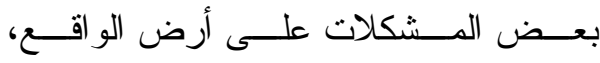
ولعل من أبـرز هــــهـ المـشكلات كثــرة

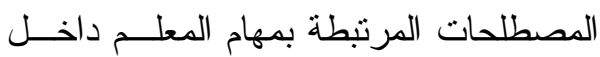

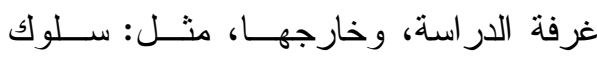
خصائص، كفاءة، عمل، أداء، أفعال... وكل مله

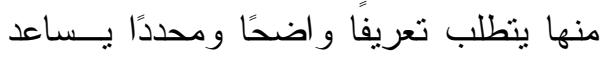

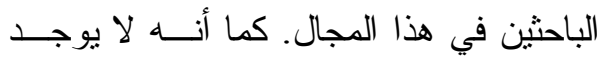

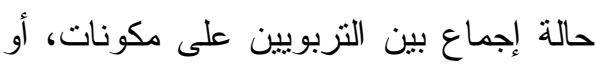

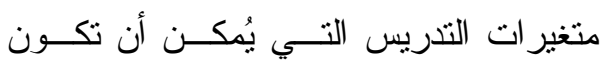
عرضة للفحص الدقيق أو قابليتها للتقويم من بمن ان
1- الكفايات الوظيفيــة: Professional

Competency

تُعرف الكفاية بأنها قدرة المعلم علـى

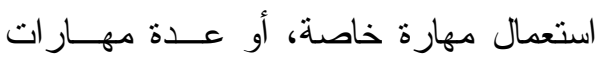
وظيفية استجابة لمتطلبات موقــف تربــوي

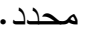

r- المعسايير المهنيــة: Professional Standards

هناك معايير متعددة منهــا: معسايير

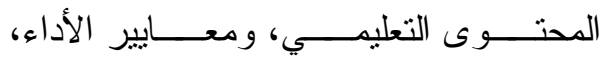
ومعايير المنــاهج و المقــررات الدر اســـية. وبشكل عام يُمكن اعتبار المعايير وصفا دقيقًا

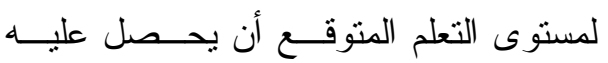
الطالب المعلم بعد انتهاء برنــامج الإعــــاد

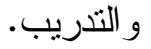

T- ب- ملفات الأعمال المهنيــة: Teaching

\section{Portfolio}

ظهرت ملفات نقويم أداء المعلم نتيجة

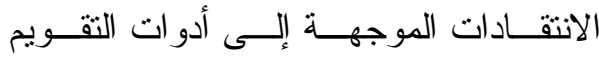

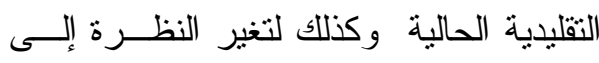

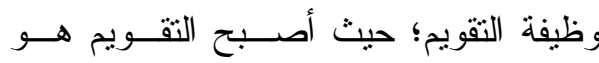
الموجه الأول للعملية التعليمية.

وفي هذا الثأن تتفق كثير مــن آراء

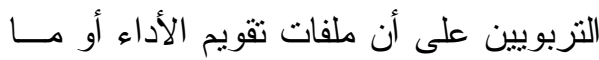

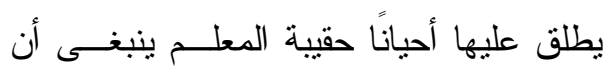

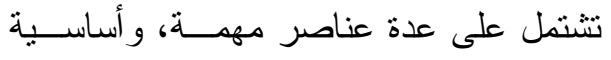
تُسهم في إعطاء صور و اقعيــة عـنـ الأداء 
المتمايز استر اتيجية فعالة في التدريس، فـي

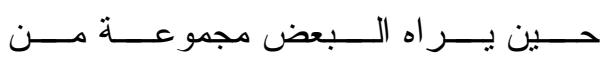

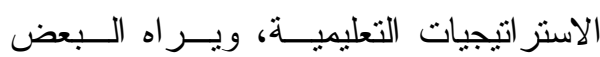

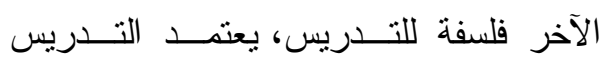

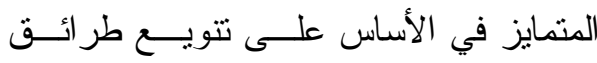

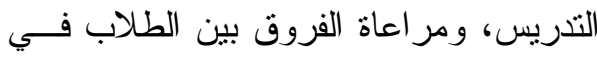

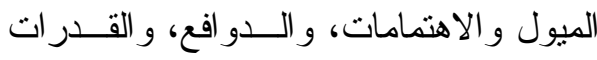

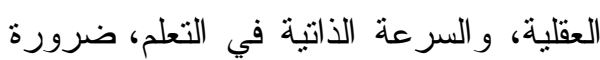
تتمنل في الكثثف عـن الخبــرات الــسابقة

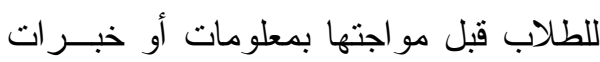
جديدة.

ب- أسس التدريس المتمايز : ذكرت كوثر كوجلك وآخرون

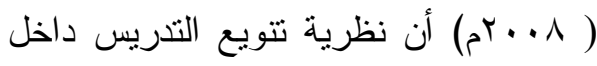

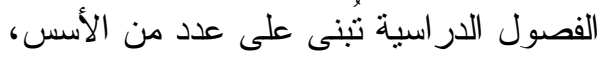
ومن أهمها:

الأسس القاتونية، الأسس النفسية، الأسس الهس

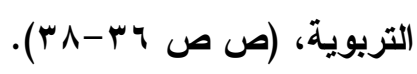
ويرى الباحث أن استخدام الوقت بشكل

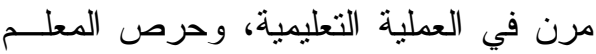
على توفير الاحتر ام لجميع الطلاب، وتقدير

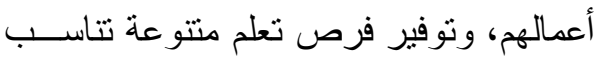
التتوع الكبير في احتياجــاتهم و اهتمامــاتهم ودو افعهم، وميــــولهم، وخلفيــاتهم الثقافيــة، و استخدام طر ائق مختلفة في التدريس يُعد من ون أهم الأسس التي يقوم عليها التدريس الفعــال في الصف المتمايز.

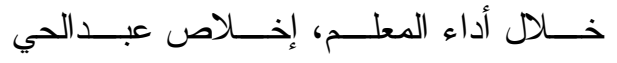

يرى الباحث أن هناك ضرورة ملحسـة

للبحث و التقصي في الصعوبات أو المشكلات

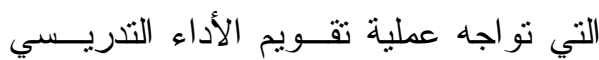

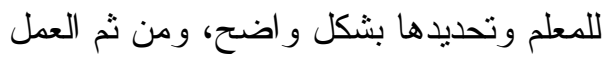
على وضع الخطط العلاجية اللازمــة لهــــا

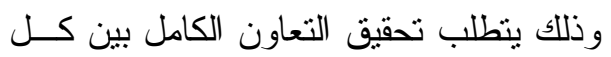
الأطر اف المعنية بذلك. r - التدريس المتمايز أ- ماهية التدريس المتمايز: يُعرفه محمد (10 • r م) بأنه: " مدخل

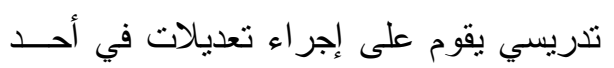
عناصر التدريس (المحتوى أو الإجراءات أو

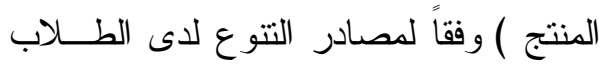

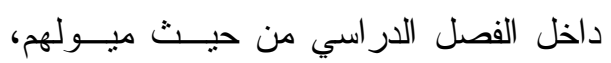

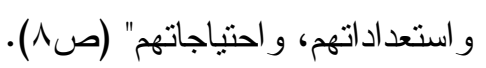

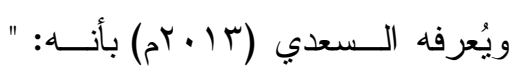

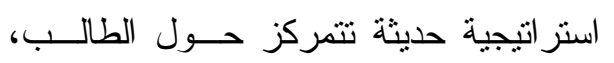

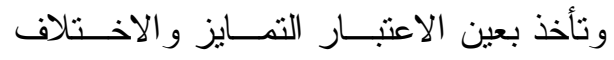

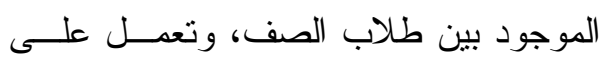
تلبية الاحتياجات و الاهنمامــات و والميــول ولعين المختلفة للطلاب" (ص99 (1). لحظ الباحث ما يلي، هنالك اخـتنلاف

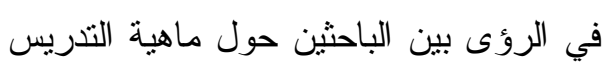

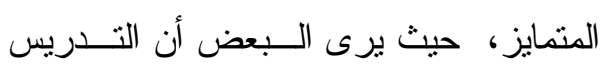


المعلم بالتخطيط لاختيار استراتيجيات

التدريس المناسبة، وتصميم الأنشطة التعليمية التي تتاسب النتوع بين الطلاب، وبعد تتفيذ التذريس يختار المعلم أساليب التقويم المتمايزة لقياس مدى نجاح التنريس وتحقيق لنقيق مخرجات التعلم.

د - مجالات التدريس المتمايز وأثثكاله:

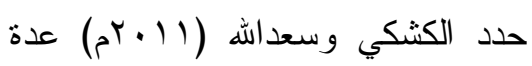
مجالات للتنريس المنمايز ، على النحو الآتي:

1- الأهداف: يمكن أن يضع المعلم أهدافًا متمايزة للطلاب.

r- الأساليب أو الإجراءات: يمكن أن يكلف

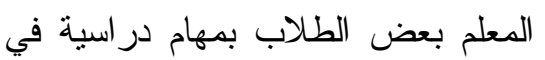

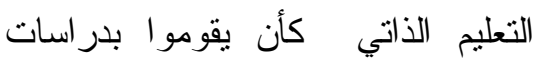
ذاتية، وعمل مشروعات وحل مشكلات،

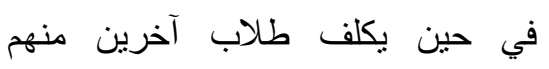
بأعمال يدوية وأخرين بمناقثات صفيه بكاب لخرين هنه

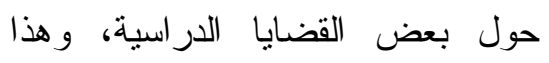
النوع من التدريس بيسى تدريساً متمايز اً حسب اهنمامات الطلاب. r- المخرجات: يمكن أن يكتفي المعلم

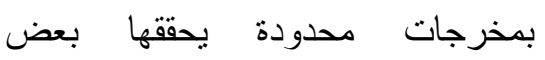
الطلاب، في حين يطلب من آخرين

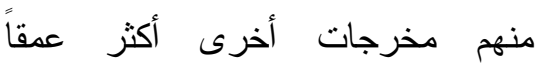
وتوسعاً، ويقبل المعلم ما بين الطلاب من تفاوت عقلي.
ج- خطوات التدريس المتمايز:

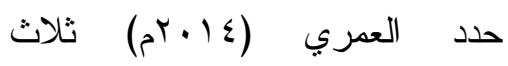
خطو ات أساسية للتدريس المتمايز : 1- يُحدد المعلم المهار ات، و القدرات لكل

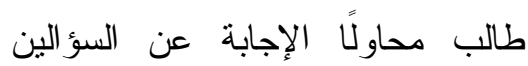
التاليين: ماذا يعرف كل طالب؟ وماذا يحتاج كل طالب؟ وعلى ذلك يُحدد

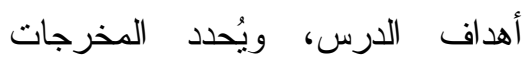
المتوقعة، كما يُحدد معايير تقويم مدى وئد تحقق الأهداف.

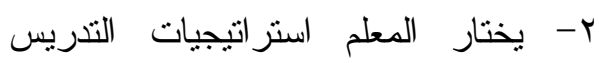
الملائمة لكل طالب، أو لكل مجموعة

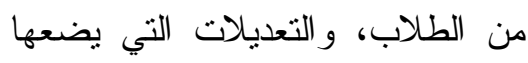
لجعل الاستر اتيجيات تلائم هذا التتوع. r- - يحدد المعلم المهام التعليمية التي سيقوم بها الطلاب لتحقيق أهداف التعلم. بتضح أنَّ معلم العلوم الثرعية عليه دور مهم يؤديه في الصف المتمايز، و هذا الدور تتضح ملامحه الرئيسة في قيامه فوديه بعملية التشخيص، أو التقويم المبدئي لطلابه قبل البدء بشكل فعلي في عملية التدريس بهدف تحديد احتياجاتهم، وقدر اتهم، وميولهم، لهئ لئهل

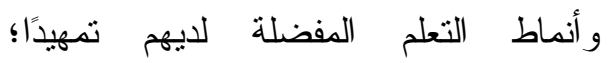
لتصنيفهر في مجموعات دراسية بحيث

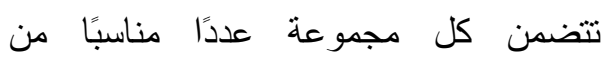

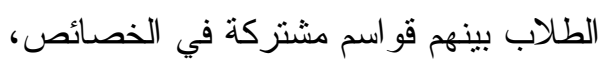

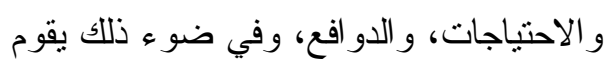




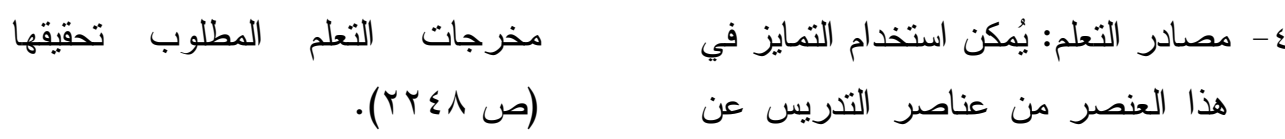

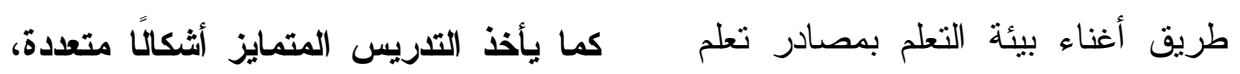
متتوعة، وتتظيمها بطريقة توفر أفضل منها:

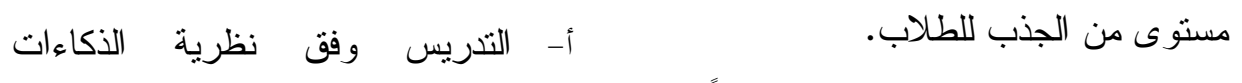
ه- التقويم: يمكن أن يكون التقويم منالًاً

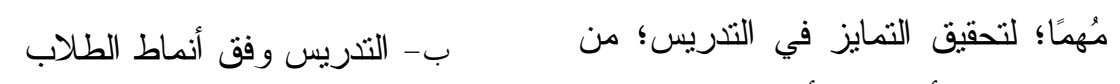

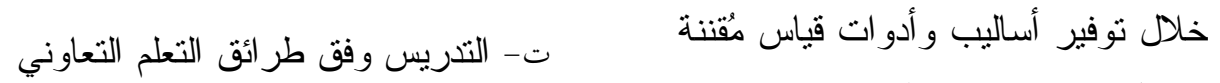

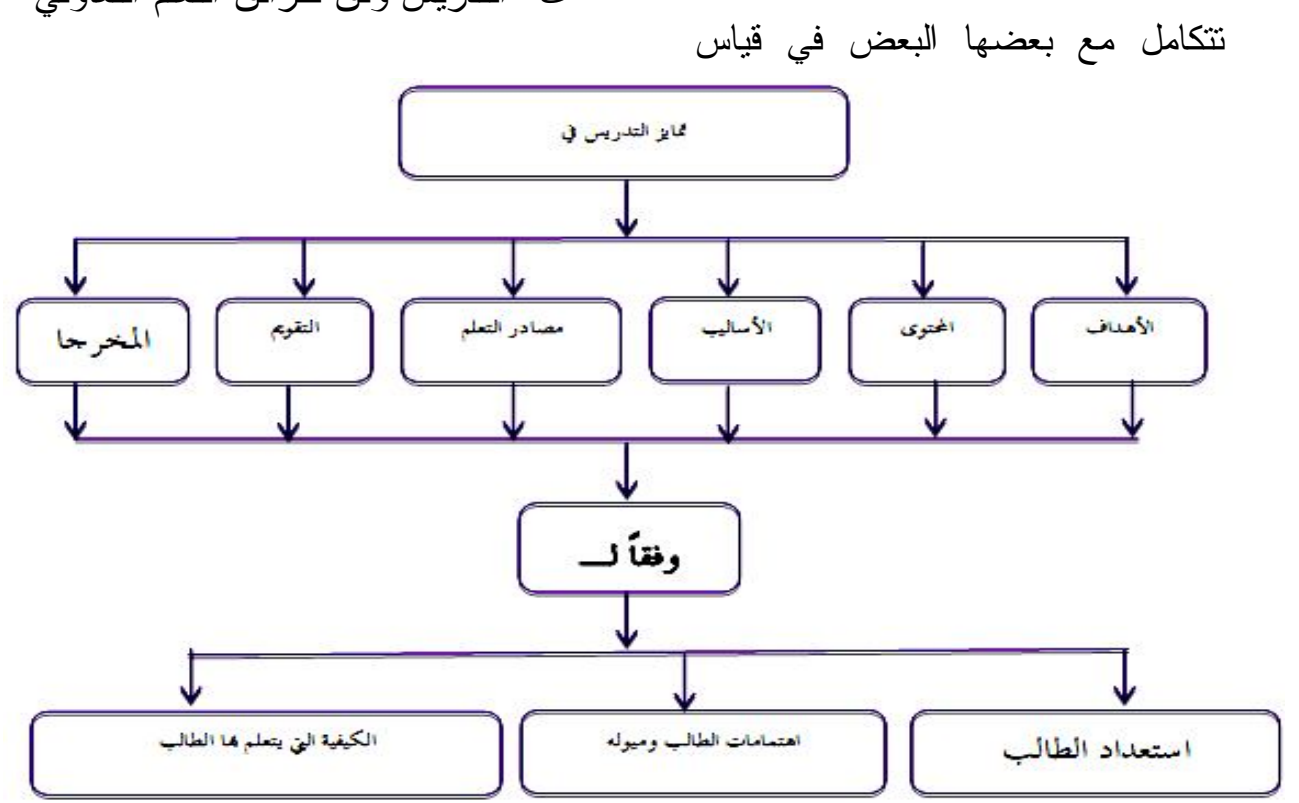

شكل (r - 1 ) مجالات التدريس المتمايز وأثنكاله

ه- استراتيجيات التدريس المتمايز

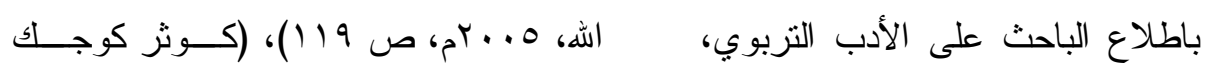

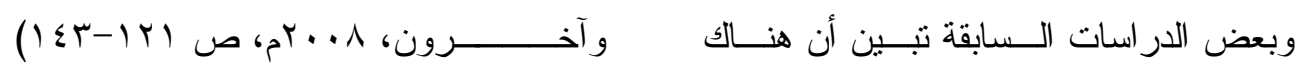

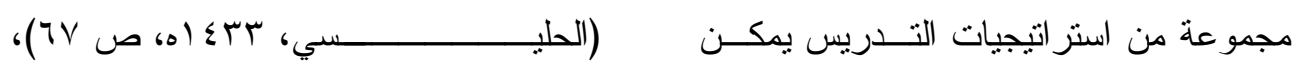

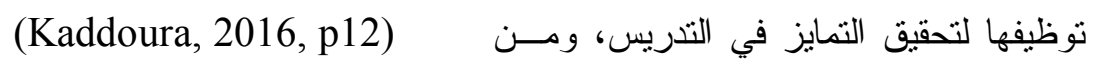
أبرز هذه الاستر اتيجيات ما يلي: (نادية لطف فئفئ 
r- أركان ومراكز التعلم: Learning

\section{Centers}

تعتمد هذه الاستر اتيجية على توفير

مجموعة من المر اكز أو الأركان التعليمية يتم

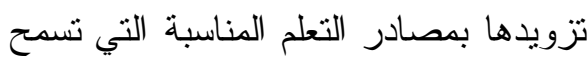

للطلاب بتتمية مهار اتهم، وتحقيق أهدافهر

وكلما كانت هذه الأركان منو افقة مع اهتمامات

الطلاب ساعد ذلك في تحقيق أهداف العملية

التعلمية.

ويــــــ الباحســـث أن اســــتر اتيجية

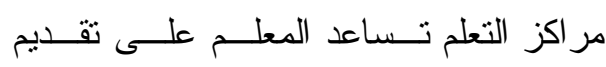

تعليم يتتاسب مع القدرات العقلية المختلفـــة فئة

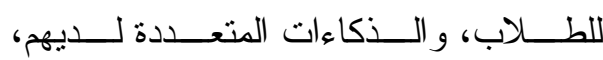

وتُتيح للطلاب الاختيار الحر في كثيــر مـنـ

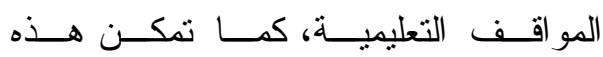

الاستر اتيجية المعلم من تقييم طلابه بطر ائق

مختلفة.

צ - عقود التعلم: Learning Contracts

وتتعتد إستر اتيجية عقود التعلم بشكل

رئيس على إثر الك الطلاب إثر اكاً فعليًا في

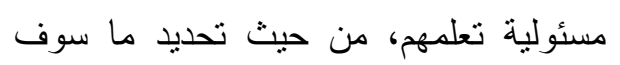

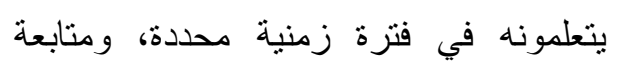

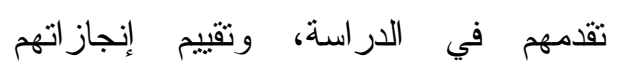
الدر اسية أولًا بأول، وتنمح هذه الاستر اتيجية لكل طالب أن يتقدم بسرعة مناسبة له وفقًا

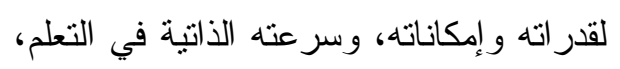
بحيث يحقق الأهداف المنشودة في نهاية
Think, : فكر - زاوج - شارك

Pair, Share

يتم التدريس وفق هذه الاستراتيجية بثلاث خطوات رئيسة، هي:

فكر بنفسك: ، زاوج مع زميله لهي: لك،

شارك الفصل كله:

ويرى الباحث أن استز اتيجية فكر

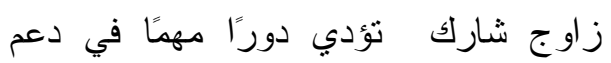

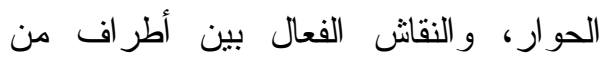

الطلاب بينهم تباين في القدرات العقلية، ولنئ

و الميول، و والاهتمامات، و الخبرات السابقة

عن الموضوع ومن ثم فإن هذه الاستر اتيجية ولية

تسهم بشكل كبير في تحقيق التمايز الفعال في تي

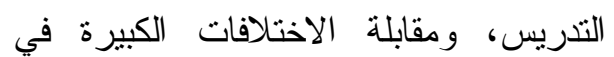

خصائص الطلاب.

Flexible المجموعات ابل المرنة: Grouping

إنَّ المبدأ الرئيس الذي يستتد إليه

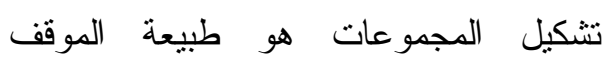

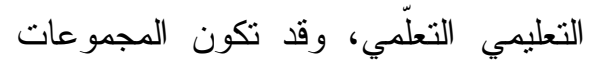
متجانسة في الاستعدادات أو الاهنمامات، أو لوني

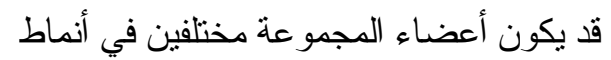

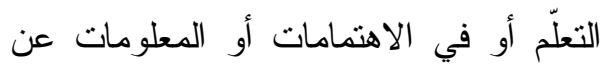

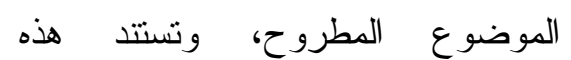
الإسنر اتيجية على أساس مهر هو أن كل طالب ونت في الفصل هو عضو في مجموعات مختلفة

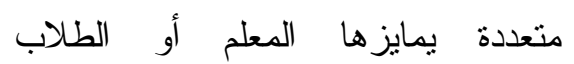


الطالب وفعاليته في تتفيذها، وتتصف بأنها أنشطة مستمرة أي ليست نشاطًا يكمله

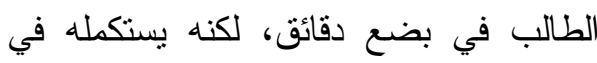
حصص متتالية. و - أوجة الاختلاف بين التعـــيم التقليـــي و التعليم المتمايز الاجناف بين

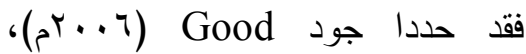

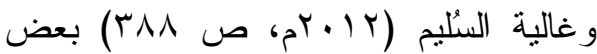
الاختلافات بين التدريس التقليدي و التدريس المنمايز كما يوضحها الجدول التالي: التدريس التقليدي والتدريس المتمايز

\section{Anchor - الأنثطة}

\section{Activities}

هي نوع من الأنشطة التعليمية التي بصممها المعلم في ضوء أهداف المنهج

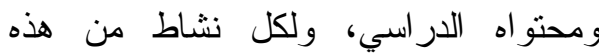
الأنشطة أهداف واضحة ومحددة، ويراعى الرالى

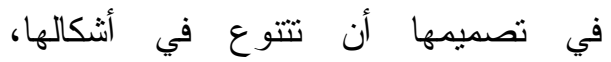

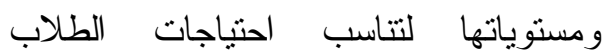
المختلفة، و اهتماماتهم وميولهم المتتوعة، كما تتصف هذه الأنشطة بأنها تعتمد على إيجابية

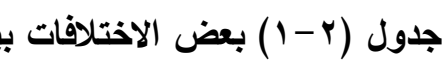

\begin{tabular}{|c|c|c|}
\hline التدريس المتمايز & التدريس التقليدي & الجانب \\
\hline 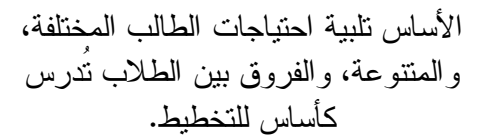 & الفروق بين الطلاب تُغطى أو تُعالج & الفروقات في الطلاب \\
\hline يعتمد معايير تعليم أساسية لكنه يأخذ أثنكالًا & منهاج و احد، مو اد تعليمية و احدة & العو امل الموجهة للتعليم \\
\hline الدرس منمركز حول الطالب، استخدام & قائم على مركزية المعلم، وجميع & أسلوب التدريس \\
\hline تؤخذ بعين الاعتبار أساليب التعلم المتلمات الطتاب. & نادر اً ما تأخذ اهتماماتهم أى حيز & اهتمامات الطلاب \\
\hline التفوق إلى حدِ بعيد يعرف بالنمو الفردي & يوجد تعريف و احد للتقوق، أو & معايير التقويم \\
\hline خيار ات متعددة للطالب، فالمهمات ذات & و اجب و احد، و المهمات ذات الخيار & نوع الو اجبات \\
\hline التركيز على أثنكال متعددة من للذكاء & لا يوجد تتوع و إنماًا هو ذكاء و احد & مر اعاة الذكاءات لدى \\
\hline 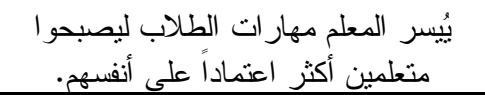 & يوجه المعلم سلوك الطلاب & دور المعلم \\
\hline الوقت يُستخدم بمرونة طبقاً لاحتياجات & الوقت غير مرن نسبياً. & وقت الدرس \\
\hline 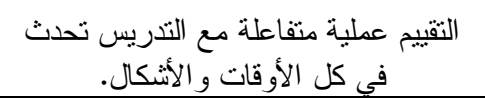 & يتم التقييم في نهاية الوحدة. & محددات التعليم \\
\hline
\end{tabular}




\section{ز - القيمة التريوية للتدريس المتمايز}

و الأساليب، و واختيار وسائل أو مصادر

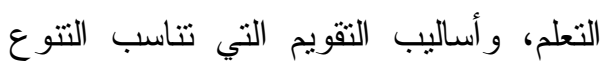
و الاختلاف في خصائص الطلاب، وتمثيلاتهم الداخلية وذكاءاتهم المتعددة، وبالنسبة للطلاب فإن التدريس المتمايز يوفر لهم فرصنًا حقبقية، ومنتوعة للتعلم الفعال وفقا لاحتياجاتهم، و اهتمامتهم وميولهم، وسر عاتهم الذاتية في التعلم. ثانيًا : الدراسات السابقة.

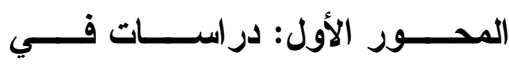
تقويم الأداء التدريسي لـى معلمي العلـــوم

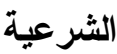

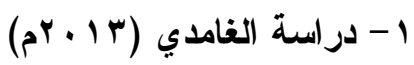
هدفت الدّرّ اسة إلى تعرف مدى تـــو افر

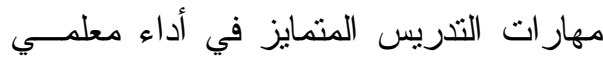
التزبية الإسلامية في المرحلـــة الابتدائيــة.

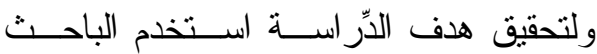
المنهج الوصفي. وتكونت عينة الدِّر اسة مسن

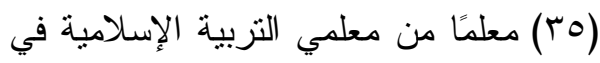

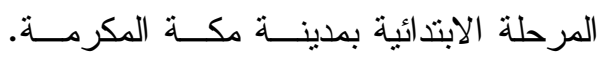

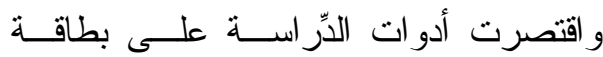
ملاحظة. وقد أظهرت نتائج الدّرّاسة أن نسبة

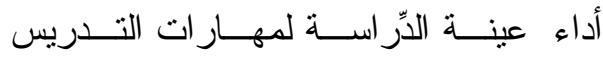
المتمايز ككل بلغت (1 (, 1\%)، و هي نسبة منخفضة جدًا، وبلغت مهارة" تصميم أنشطة

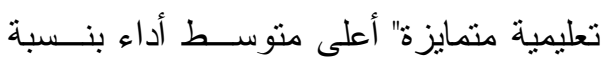

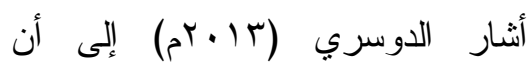
التدريس المتمايز بوصفه أحد الاتجاهات التزبوية الحديثة في التنريس يحقق العديد من المز ايا للمعلم و الطالب، منها أنه: - - يؤهل المعلمين لفتح فرص تعلم لجميع

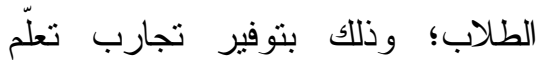
مختلفة. - - يساعد المعلمين على فهم، واستخدام التقبيم كأداة مهمة لتحريك التعليم - يضيف استراتيجيات تعليمية جديدة للمعلمين "صناديق أدوات"، وذلك بتقديم

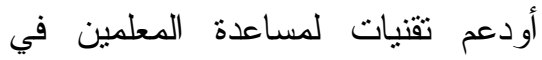
التركيز على أساسيات المنهاج الدراسي - - يلبي متطلبات المنهاج الدراسي بطريقة ذات معنى لتحقيق نجاح الطلاب. وفي ضوء ذللك، يرى الباحث أن

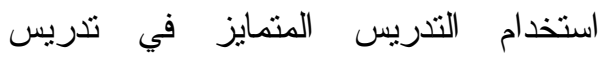
مقررات العلوم الثرعية في المرحلة الثانوية يمكن أن يسهم بشكل قوي في تحقيق الأهداف المحددة لتدريس هذه المقررات؛ من بن خلال الميزات التربوية التي يوفرها هذا لناهين النوع من التدريس سواء أكانت ميزات تتصل بالمعلم، أم بالطلاب، فبالنسبة للمعلم فإن التدريس المتمايز يوفر له فلسفة تدريس تمكنّه من وضع الأهداف وتحديد الإجر اءات 


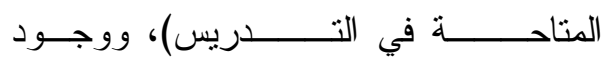
فروق دالة إحصائيًا في جميع فقرات مجــال التتفيذ؛ لصالح المعلمين الملتحقين بالــدورات الثرعية، ووجود فروق دالة إحــصائيًا فـي جميع فقرات مجال التقويم؛ لصالح المعلمين الملتحقين بالدورات الثرعية، ووجود فروق دالة إحصائيًا بــين الملتحقــــين بالــدورات

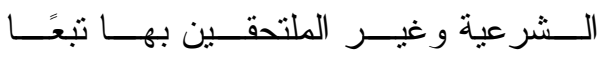

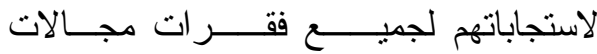

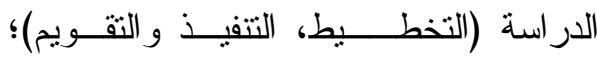
لــصالح المعلمــين الملتحقــين بالـــدورات الثر عية.

\section{التعليق على الارّر اســات فـــي المحــور}

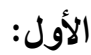

- - استهدفت الدِّر اسة الحالية معلمي العلوم الثرعية بالمرحلة الثانوية، وهي بهــذا تتَّفق مع در اســـة الزنيــدي (ع ا • rم)، بينما تختلــف مــع در اســـة الغامــدي

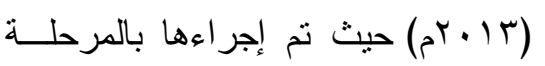
الابتدائية. - اتفقت الدِّر اسة الحالية مع در اسة ودر اسة الغامدي (r ا • rم)، ودر اســـة الزنيــدي

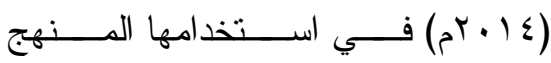
الوصفي، وكذلك في أداة الدِّر اسة، وهي بطاقة الملاحظة. - تختلف جميع الدِّر اسـات في هذا المحــور عن الدِّر استة الحالية في هدفها، فالدِّر اســـة

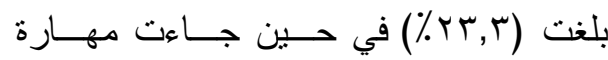
"استخدام استر اتيجيات التذريس المتمايز " أقل متوسط أداء بنسبة بلغت (1,V) (1\%)، وجميع هذه النسب منخفضة، ورلا تــل لمـستوى الأداء المطلوب وهو .^ \% فأكثر. r - دراسة الزنيدي (ع ا م rم) هدفت الدّرّ اسة إلى إبراز أوجه المقارنة في التحاق معلمي التربية الإســـلامية أثتـــاء الخدمة في الدورات الثرعية بغير الملتحقين على الأداء التدريسي في مجالات: التخطيط، و التتفيذ و التقويم. وتكونت عينة الدِّر اسة من

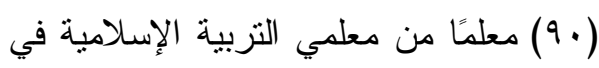

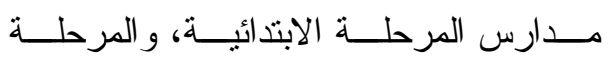
المتوسطة و المرحلة الثانوية في إدارة التربية

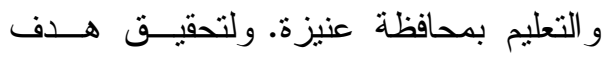
الآرّر اسة استخدم الباحث المــنهج الوصــفي. وتكون مجتمع الدِّر اسة من معلمــي التربيــة الإسلامية الملتحقين بالدورات الثرعية وغير الملتحقين (مدارس البنــين) فـــي محافظـــة عنيزة. و اقتصرت أدوات الدِّر اسة على بطاقة ملاحظة. وقد أظهرت نتائج الدِّر اسة وجــود فروق دالة إحصائيًا في جميع فقر ات مجــال

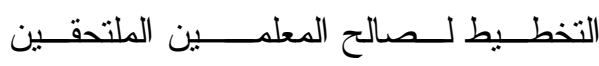
بالــدور ات الثــرعية ما عــــا الفقــــرات التالية: (يصـــوغ أهـــداف الدرس صــياغة سلوكية معرفيــة ومهارية ووجدانية- يخطط

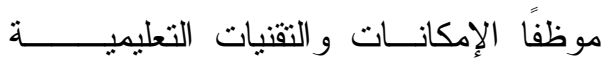


الطلاب عن عملية التعلم.

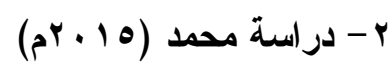

هدفت الدّر اسة إلــى تعــرف فعاليـــة

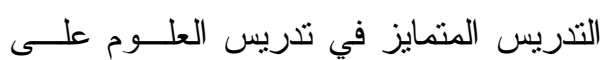

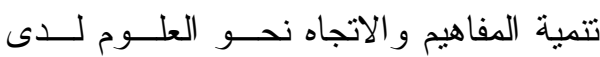
تلاميذ المرحلة الابتدائية بالمملكـــة العربيـــة السعودية. ولتحقيق أهداف الدّر اسة اســتخدم الباحث المنهج شبه التجريبي. وتكونت عينة

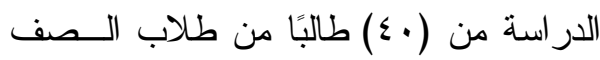

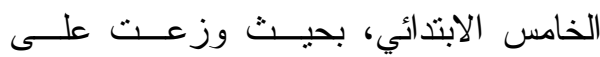
مجموعتين، الأولى: تجريبية تدرس باستخدام مدخل التدريس المتمايز و الثانيـــة: ضـــابطة تدرس باستخدام الطريقة المعتادة. و انتــتملت أدو ات الدرّ اسة على اختبار المفاهيم ومقياس الاتجاه نحو العلوم. وقد كثفت نتائج الدّرّاسة عن وجود فروق دالة إحصائيًا بين متوسطي درجات طلاب المجموعة التجريبية، وطلاب المجموعة الضابطة فـي التطبيــق البعــدي

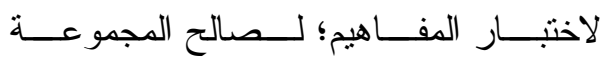
التجريبية، ووجود فروق دالة إحصائيًا بـين

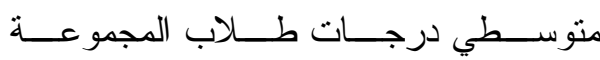
التجريبية، وطلاب المجموعة الضابطة فـي التطبيق البعدي لمقياس الاتجاه نحو العلــوم؛ لصالح المجموعة التجريبية.

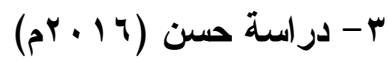
هدفت الدّرّاسة إلى تعرف أثزر التدريس المتمايز في تحصيل طلبة قسم التزبية الفنبـــة
الحالية تهذف إلى إعداد قائمة بالمهار ات

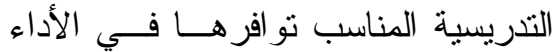
التدريسي لدى معلمي العلــوم الــشرعية

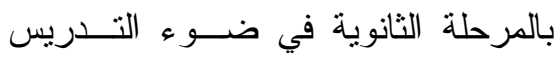

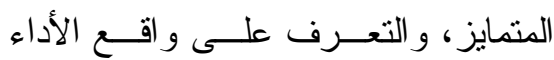
التدريسـسي لمعلمــي العلـــوم الــشر عية

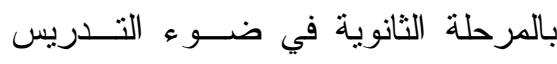
المتمايز ، ووضع تصور مقترح؛ لتحسين

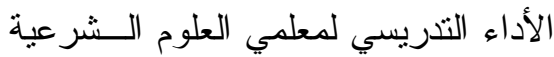

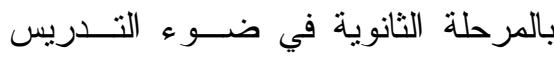

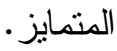

المحور الثاني: دراسات في التدريس المتمايز

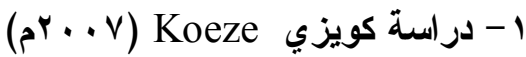
هدفت الدرّ اسة إلى تحديد ما إذا كـــان

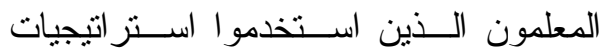
التدريس المتمايز قد أثزووا بشكل كبير علــى تحصيل طلابهم في مجال الرياضيات مقارنة

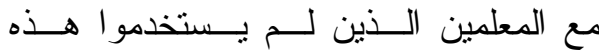

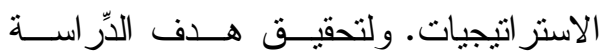
استخدم الباحث المنهج الوصفي. و اثــتملت أدو ات الدّرّ اسة على بطاقة الملاحظة وبطاقة المقابلة مع المعلمين. وتكونت عينة الدراسة

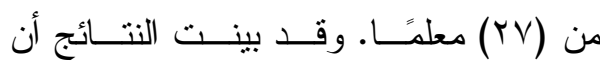
استر اتيجيات التمايز في التنريس التي نتنمل

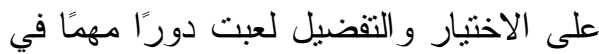
التحصيل الدراسي، وتحسين مستوى رضــــا 


$$
\begin{aligned}
& \text { محمد (10 • rم) حيث اســتخدم المــنهج } \\
& \text { شبه التجريبي. } \\
& \text { - تختلف جميع الدّر اسات السابقة في هــذا } \\
& \text { المحور عن الدِّر اسة الحالية في هـــدفها، } \\
& \text { فالدِّر اسـة الحالية تهدف إلى إعداد قائمـــة } \\
& \text { بالمهار ات التدريسية المناسب ثو افرها في } \\
& \text { الأداء التذريسي لــدى معلمــي العلــوم }
\end{aligned}
$$

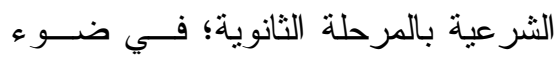

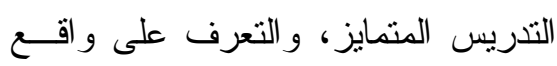

$$
\begin{aligned}
& \text { الأداء التدريسي لمعلمي العلوم الـشرعية } \\
& \text { بالمرحلة الثانوية في ضـــوء التـدريس } \\
& \text { المتمايز ، ووضع تصور مقترح؛ لتحسين } \\
& \text { الأداء التدريسي لمعلمي العلوم الــشرعية } \\
& \text { بالمرحلة الثانوية في ضـــوء التــدريس } \\
& \text { - المتمايز }
\end{aligned}
$$

- تتفق الدّاّرسة الحالية في استخدامها بطاقة

Koeze الماحظة مع در اسة كـــيزي

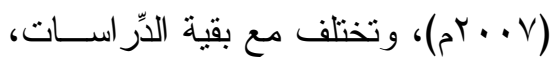
حيث استخدمت در اسة محمــد (10 • r م) اختبار المفاهيم العلمية، ومقياس الاتجـــاه نحو العلوم، و استخدمت در اســـة حسـسن (T 1 • rم) اختبار التحصيل المعرفي. أوجه استفادة الإِّراسة الحاليــة مــن

$$
\text { الار اسات السابقة: }
$$

استفادت الدِّراسة الحالية من الدِّر اسات

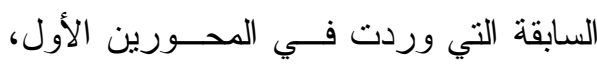
و الثاني في الآتي:
في مادة تاريخ الفن. ولتحقيق هدف الدر اسة استخدم الباحث المنهج التجريبي. وتكونـــ

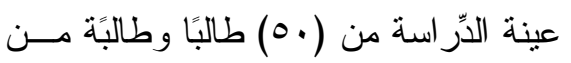

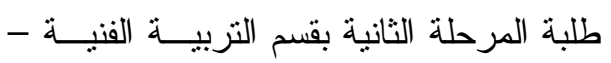

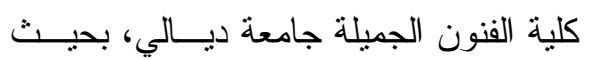

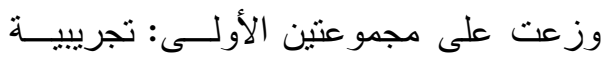
تدرس باستخدام التذريس المتمايز ، و الثانيـــة: ضابطة تدرس باستخدام الطريقة المعتــادة . و اقتصرت أدوات الدِّر اســـة علــى لـتى اختبــار التحصيل المعرفي. وقد كثفت نتائج الدِّر اسة عن وجود فروق دالة إحصائيًا بين منوسطي درجات طلاب المجموعة التجربيية، وطلاب المجموعة الضابطة فــي التطبيــق البعـــي لاختبار التحصيل المعرفي؛ لصالح طـلاب المجمو عة التجريبية. التعليق على الار اســـات فــي المحـــور الثاني: - أكدت الدِّر اسـات السابقة في هذا المحـــور فعالية التدريس المتمايز في تحسين الأداء التدريسي لاى المعلم و وتحقيـق بعــض نواتج التعلم لدى الطلاب، كما كثفت عن بعض المعوقات التي نو اجه نتفيذه. - تتفق الدّر اسة الحاليـــة فـــي اســتخدامها المنهج الوصفي مـــع دراســـة كـــويزي Koeze

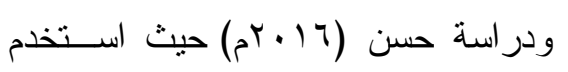
المنهج التجريبي، كما اختلفت مع در اسة 


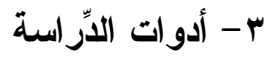 أ- قائمة المهارات التدريسية}

قام الباحث بوضـــع قائمــة مبدئيـــة

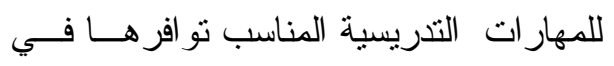
الأداء التدريسي لدى معلمي العلوم الثرعية بالمرحلة الثانوية في ضوء التنريس المنمايز تضمنت خمس مهار ات رئيسة، هي: (ممايزة الأهـــاف - ممــايزة المحتــوى - مدــايزة الإجر اءات- ممايزة مصادر التعلم- ممــايزة

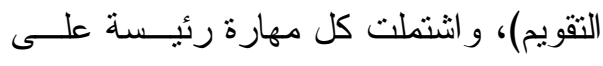
عدد من المهارات الفرعية بلغ عددها (YT) ثلاث و عشرون مهارة فر عية. ج- - عرض القائمة على المحكمين عُرضت قائمة المهار ات التدريسية التي تم التوصل إليها على مجموعة من المحكمين

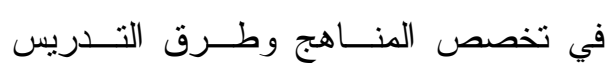
العامة، ومناهج وطرق تدريس العلوم ، وقد

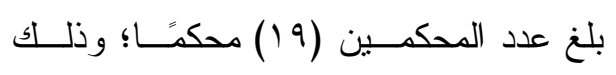
بهدف التأكد من أهمية المهــار ات الرئيسـسة و الفرعية المتضمنة في القائمة، و انتماء كـلـل

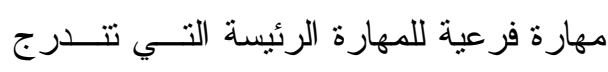

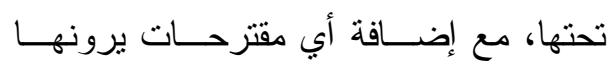

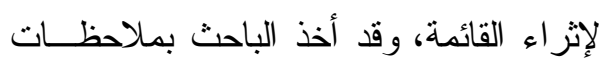
المحكمين، حيث تم تعديل الصياغة اللغويـــة وفئة

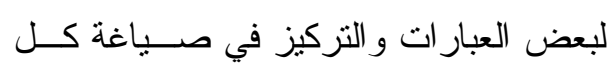

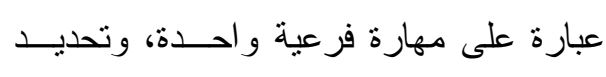

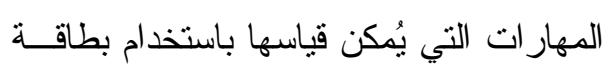

- - بناء الإطار النظري للادّر اســـة الحاليـــة، وصياغة أسئلة الدّر اسة.

- اختبار منهج البحث المناسب للدرّ اســـة

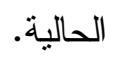

- - اختيار الأساليب الإحــصائيَّة المناســبة للدرّ اسة الحالية. - - تقسير نتائج الدِّر اسة الحالية، ومناقشتها في ضو ء نتائج الدِّر اسات السابقة.

منهجية الدراسة وإجرائاتها 1 - منهج الدِّراسة

لتحقيق أهداف الدِّراسة الحالية استخدم

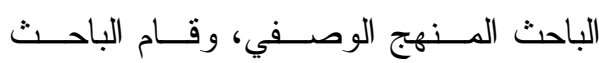
بالملاحظة المباثرة للأداء التذريسي لجميـع لونع

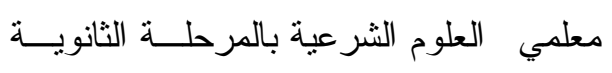

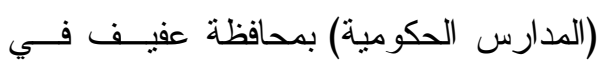
ضوء التدريس المتمايز ، وإجر اء مقابلة مقننة معهم؛ لوصف الظاهرة المدروسة من حيــث طبيعتها، ودرجة وجودها.

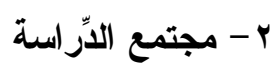
تكون مجتمع الدّرّاسة من جميع معلمي

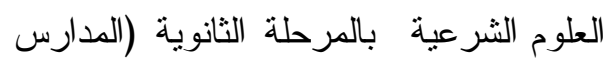

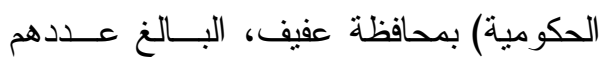

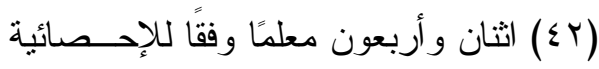

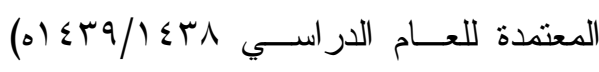

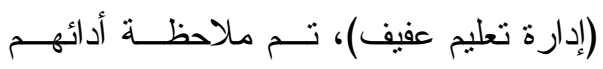
التدريسي، و إجر اء المقابلة معهم. 
التعديلات قبل تطبيق البطاقة علـــى العينــة الاستطلاعية، وبذلك يكون الباحث قد تحقــق من الصدق الظاهري لبطاقة ملاحظـــة الأداء التدريس لمعلمي العلوم الشرعية بالمرحلــة الثانوية في محافظة عفيف. - الصدق العاملي (صدق الاتساق الداخلي) بعد التحقــق مــن الــصدق الظـــاهري (المنطقي) لبطاقة المالاحظة، قــام الباحـــث بتطبيق بطاقة الماحظة علـىى عينــة مــن معلمي العلوم الثرعية بالمرحلة الثانوية في محافظة عفيف، وقد بلغ حجم العينــة (T) ستة و عشرين معلمًا مــن ضـــمن مجتمــع

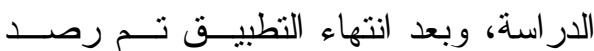
الــدرجات فـي جــدول (ملحــق رقــب)، وباستخدام برنامج الحزم الإحصائية للعلـــوم الاجتماعية (SPSS) تــم حسـساب معامـلـ ارتباط بيرسون (Pearson) بين درجة كــل

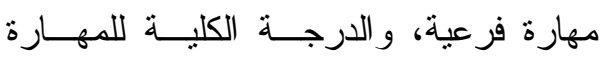
الرئيسة المنتمية إلبها، وكانت النتائج كما هي موضحة في الجدول الآتي:
الملاحظة، ونلك التي يُمكن قياسها باستخدام بطاقة المقابلة بتوجيه من ســـادة المــشرف على هذه الدر اسة. و على ذللك، تم التوصــل لقائمة المهار ات التدريـسية فـي صـــورتها النهائية .

\section{ب - بطاقة الملاحظة} ـ صدق بطاقة الملاحظة

تم التوصل لــصدق بطاقــة الماحظــة بطريقتين كالآتي: - الصدق الظاهري (المنطقي): للتحقق من الصدق الظاهري (المنطقي) لبطاقة الملاحظة؛ قام الباحث بعرضها علـى مجمو عة من المحكمين في تخصص المناهج وطرق التدريس العامة، ومنــــاهج وطــرق تدريس العلوم الثرعية و عددهم (9 (19) محكمًا

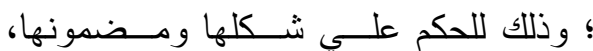
وصلاحيتها للتطبيق، وقد أجمع المحكمــون علي أن بطاقة الملاحظة تقيس ما وضـــت

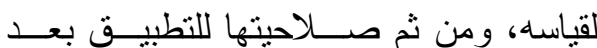
إجراء التعديلات اللازمة، وقد تم إجر اء هذه 
جدول (r-ه) قيمة معاملات الارتباط بين درجة كل مهارة فرعية، والدرجة الكلية للمهارة

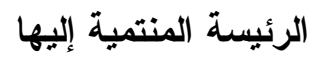

\begin{tabular}{|c|c|c|}
\hline الالالة الإحصائية & معامل ارتباط المهارة الفرعية بالمهارة الرئيسة & 5 \\
\hline \multicolumn{3}{|c|}{ وَلًا: مهارة ممايزة المحتوى } \\
\hline 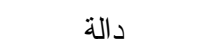 & $* * \cdot, \wedge \Sigma$ & 1 \\
\hline 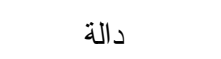 & $* * \cdot, \wedge 1$ & r \\
\hline 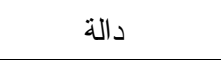 & $* *, \vee \vee 9$ & $r$ \\
\hline \multicolumn{3}{|c|}{ ثانيًا: مهارة ممايزة الإجراءات } \\
\hline 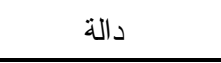 & $* *, \wedge T$ & 1 \\
\hline 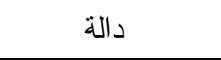 & $* *, \wedge r$ & r \\
\hline 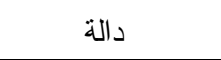 & $* *, V r$ & $r$ \\
\hline \multicolumn{3}{|c|}{ نالثًا: مهارة ممايزة مصادر التعلم } \\
\hline 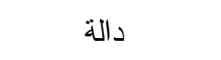 & $* *, 91$ & 1 \\
\hline 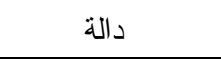 & $* *, \wedge \uparrow$ & r \\
\hline \multicolumn{3}{|c|}{ رابعًا مهارة ممايزة التقويم } \\
\hline 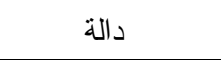 & $* *, 97$ & 1 \\
\hline 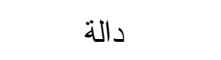 & $* *, \wedge \uparrow$ & r \\
\hline
\end{tabular}

كما نم حساب معامل ارتباط بيرسون

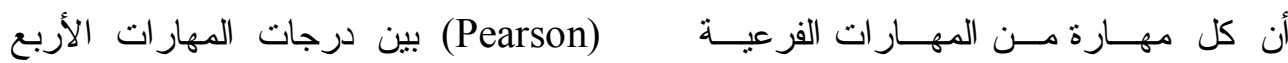

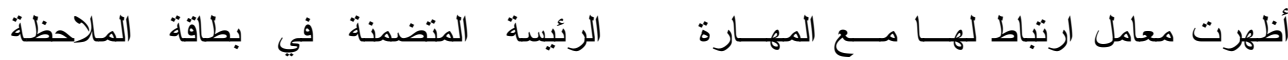

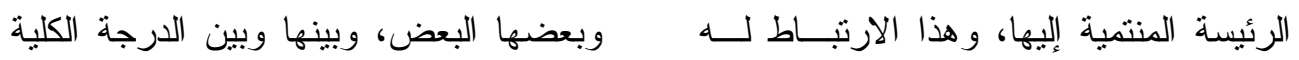

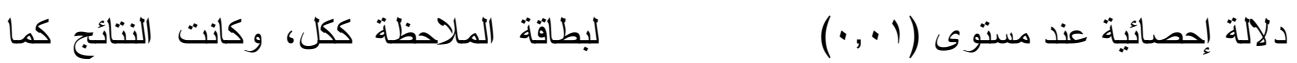

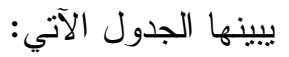


جدول (r- - ) معاملات الارتباط بين درجات المهارات الأربع الرئيسة المتضمنة في بطاقة الملاحظة وبعضها البعض وبينها وبين الدرجة الكلية لبطاقة الملاحظة ككل

\begin{tabular}{|c|c|c|c|c|c|}
\hline الملاحظة ككل & مهارة ممايزة & مصادر ممايزة & مهارة ممايزة & مهارة & المحاور \\
\hline$* *, \wedge)$ & rT, ש & $* *, \vee$. & **., or & - & مهارة ممايزة المحتوى \\
\hline$* *, \wedge 9$ & $* \%, 70$ & $* *, \vee \wedge$ & - & **, or & مهارة ممايزة \\
\hline$* *, 9$. & $* *, 7 \leq$ & - & $* *, \vee \wedge$ & $* *, V$ & مهارة ممايزة مصادر \\
\hline **, • & - & $* *, 7 \varepsilon$ & $* *, 70$ & ***, Tr & مهارة ممايزة التقويم \\
\hline- & **, ^ & $* *, 9$. & $* *, \wedge 9$ & $* *, \wedge 1$ & بطاقة الملاحظة ككل \\
\hline
\end{tabular}

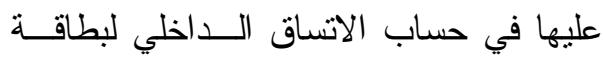

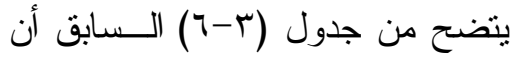

الملاحظة، حيث تم تطبيق معادلة ســبيرمان النسان

معاملات الارنباط بين درجــات المهــار ات

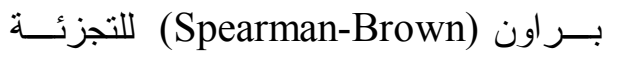

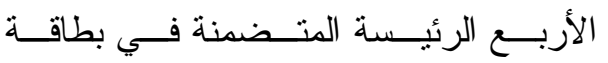

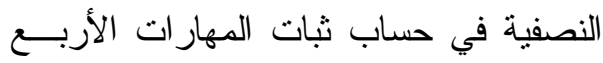

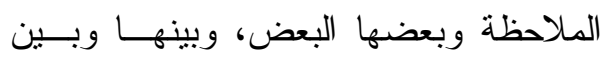
الرئيسة المكونة لبطاقة الملاحظة، و للبطاقة ككل، وكانت النتائج كما هي موضحة فيطه فئه

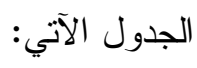

الدرجة الكلية لبطاقة الملاحظة ككـلـ دالـــة إحصائيًا عند مستوى دلالة (1 (., •).

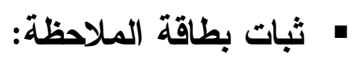

لحساب معامل ثبات بطاقة الملاحظة

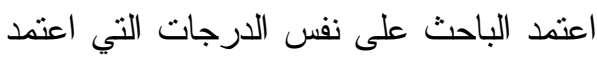
جدول (Y-Y) معاملات الارتباط، والثبات للمهارات الأربع الرئيسة المكونة لبطاقة الملاحظة، وللبطاقة ككل حسب طريقة التجزئة النصفية

\begin{tabular}{|c|c|c|}
\hline معامل الثبات (ر'") & معامل الارتباط (ر) & المهارات \\
\hline$\cdot, \mathrm{V}$ & $\cdot, 71$ & ممايزة المحنوى \\
\hline , vo &., 7 & ممايزة الإجر اءات \\
\hline$\cdot, \mathrm{V} r$ &., $\mathrm{OV}$ & ممايزة مصادر التعلم \\
\hline$\cdot, \lambda)$ & $\cdot, 71$ & ممايزة التقويم \\
\hline . 94 & $\cdot, \wedge \wedge$ & البطاقة ككل \\
\hline
\end{tabular}

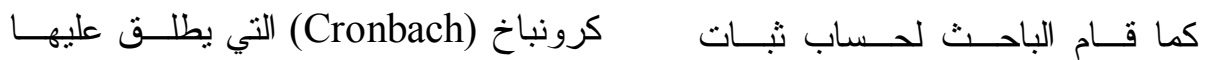

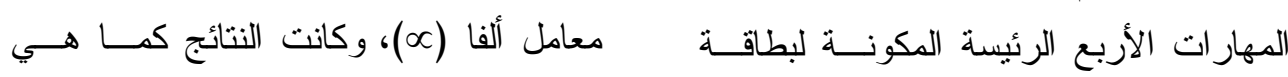
الملاحظة، وللبطاقة ككل بتطبيق معادلة ألفا موضحة في الجدول الآتي: 
جدول (r-^) التباينات، ومعامل الثبات للمهارات الأربع الرئيسة المكونة لبطاقة الملاحظة،

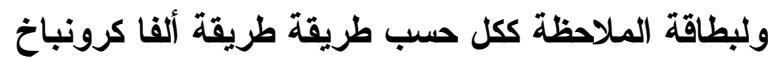

\begin{tabular}{|c|c|c|}
\hline معامل ألفا (عه) & التباين & المهارات \\
\hline$\cdot, 70$ & 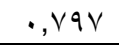 & ممايزة المحتوى \\
\hline$\cdot, 77$ &., 0.0 & ممايزة الإجر اءات \\
\hline$\cdot, V T$ & $\cdot, 07$ & ممايزة مصادر التعلم \\
\hline$\cdot, V \leqslant$ &., $77 r$ & ممايزة التقويم \\
\hline$\cdot, \wedge 7$ & $\mid r, \leqslant \Lambda$. & البطاقة ككل \\
\hline
\end{tabular}

ومن نتائج جـدول (Y-r)، وجـدول

للتأكد من ثبات بطاقة المقابلة استعان

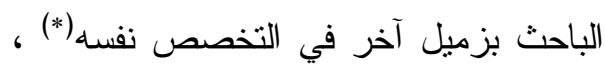

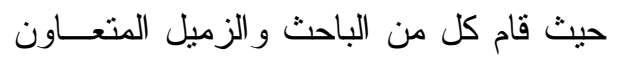
بشكل منفرد بعملية تحليل مسنقلة لإجابـات

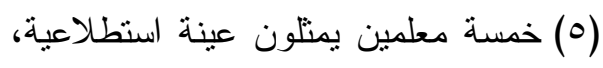

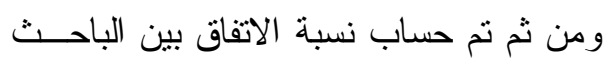

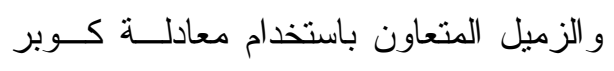
Cooper

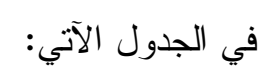

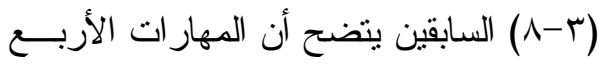
الرئيسة المكونة لبطاقة الملاحظة، وبطاقـــة الملاحظة ككل تتميز بقيم مناسبة من الثبات. ج- بطاقة المقابلة • - ل صدق بطاقة المقابلة للتحقق من صدق بطاقة المقابلة، قــام الباحث بعرضها على مجموعة من المحكمين

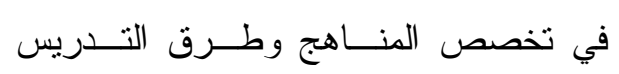

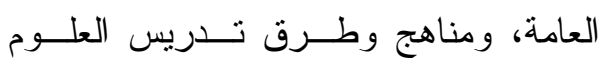

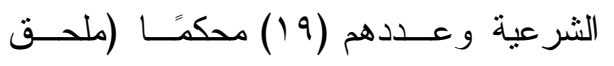
رقم ()؛ للحكم على بنود البطاقة مسـن حيــث

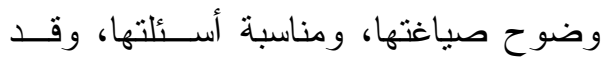

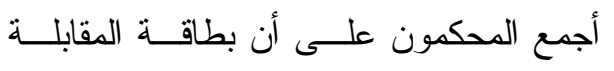

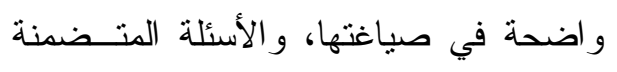
فيها مناسبة. 
جدول (r- ـ 1) نتائج معامل الاتفاق بين الباحث والزميل المتعاون في بطاقة المقابلة

حسب معادلة كوبر Cooper

\begin{tabular}{|c|c|c|c|c|c|}
\hline الاتفبة & عدات مرات الاخفتاقف + عدد & عداتد مرات & عدد المهارات & المهار ات الرئيسة & b \\
\hline$\%$. 0 & $r$. & IV & $\varepsilon$ & ممايزة الأهداف & 1 \\
\hline$\%$. & 10 & ir & r & ممايزة الإجر اءات & $r$ \\
\hline$\%$ & 1. & 9 & $r$ & ممايزة مصادر التعلم & $r$ \\
\hline$\% 90$ & $r$. & 19 & $\varepsilon$ & ممايزة التقويم & $\varepsilon$ \\
\hline$\% \wedge \wedge$ & 70 & ov & $\pi$ & المجمو ع & \\
\hline
\end{tabular}

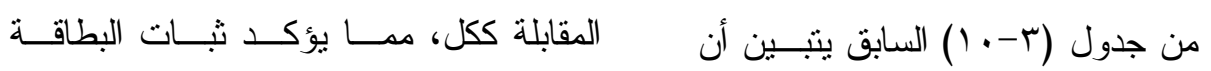

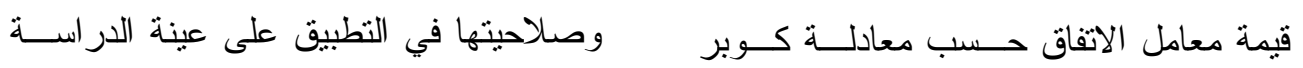

Cooper

بالنسبة لكل مهارة رئيسـة مـنـ المهــار ات الثانوية في محافظة عفيف.

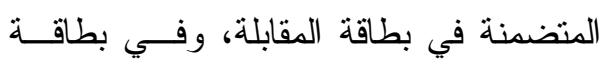

• وصف بطاقة المقابلة في صورتها النهائية

جدول (r-11) توزيع عبارات بطاقة المقابلة على المهارات الأربع الرئيسة، وأوزاتها النسبية

\begin{tabular}{|c|c|c|c|c|c|}
\hline الأوزان & عدد الأسئلة & عدد المهار ات الفرعية & أرقام المهارات الفرعية & المهارات الرئيسة & 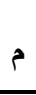 \\
\hline$\% r \cdot, \wedge$ & $\varepsilon$ & $\varepsilon$ & 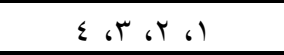 & ممايزة الأهداف & 1 \\
\hline$\% r r, 1$ & $r$ & $r$ & $\begin{array}{ll}r, r_{6} \\
\end{array}$ & ممايزة الإجر اءات & $r$ \\
\hline$\% 10, r$ & $r$ & $r$ & r. & ممايزة مصادر التعلد & $r$ \\
\hline$\% r \cdot, \wedge$ & $\varepsilon$ & $\varepsilon$ & ) ו ז، ז، & ممايزة التقويم & $\varepsilon$ \\
\hline$\% 1 \ldots$ & 14 & 14 & \multicolumn{3}{|c|}{ الإجمالي } \\
\hline
\end{tabular}

وقد اعتمد الباحث طريقة ليكرت توضيحها في الجزء الخاص بخطوات إعداد

Lekert

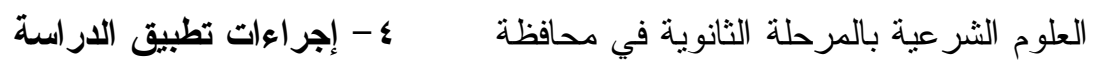

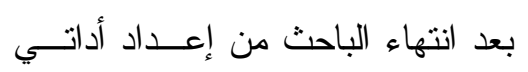

عفيف بعد انتهاء المقابلة، وهي نفس الطريقة

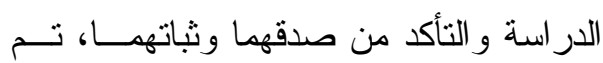

التي اتبعها الباحث في بطاقة ملاحظة الأداء

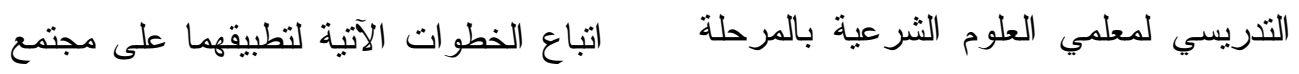

الثانوية في ضوء التذريس المتمايز التي تم 
- بعد الانتهاء من زيــارة المعلمـين مجتمع الدر اسة- تم إدخال البيانــات لئات

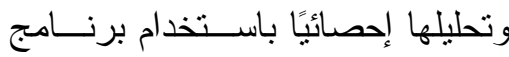

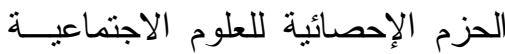

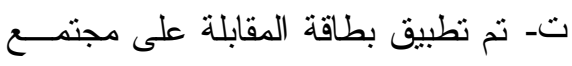
الدر اسة، وذلك من خلال قيام الباحث

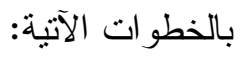

- تعريف المعلمين - مجتمع الدراسةبالهدف الرئيس من إجــر اء المقابلـــة

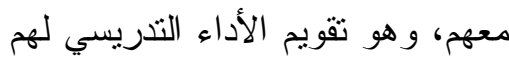

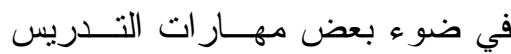

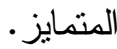
- التأكيد للمعلمين أن نتائج المقابلة معهم

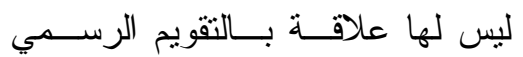

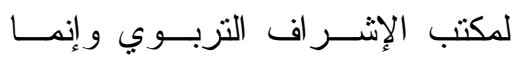
تقتصر هذه النتائج على أغر اض هذه الأر اسة فقط. - إجر اء المقابلة مع المعلمين - مجتمع الدراسة- داخل المدرسة بشكل فردي العي

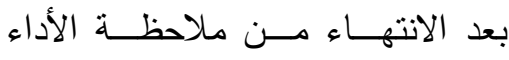

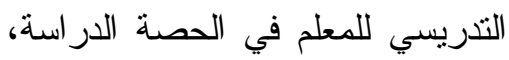
وتدوين إجابات المعلم بشكل مفـصل

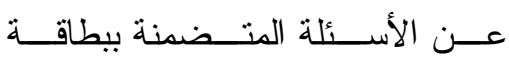

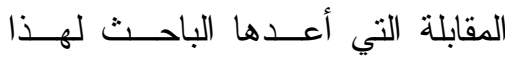
الغرض.

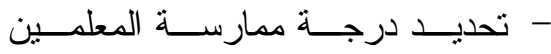

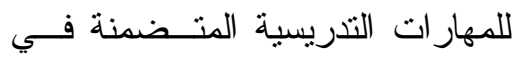

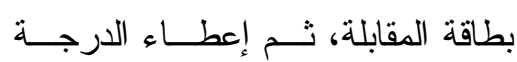

أــ الحصول على الخطابــات الإداريـــة

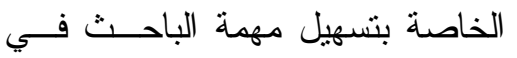
تطبيق أداتي الدراسة.

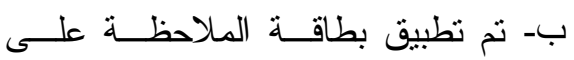

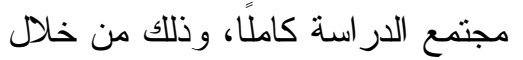
قيام الباحث بالخطو ات الآتية:

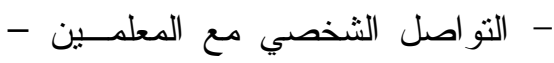

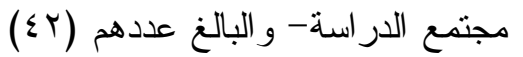

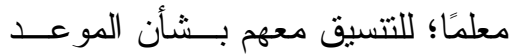
المناسب لهم لإتمام الزيارة الصفية. - تعريف المعلمين - مجتمع الدراسةبالهدف الرئيس من ملاحظة أدائهـم التدريسي، وهو تقويم هذا الأداء فـي مني لئي

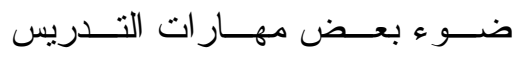

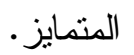
- - التأكيد للمعلمين - مجتمع الدراسة-

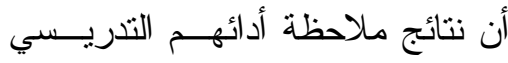

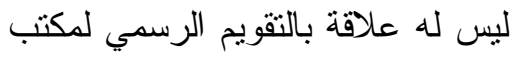
الإثراف التزبوي، و إنما تقتصر هذه

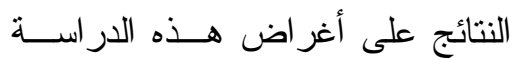
فقط. - زيارة المعلمين - مجتمع الدراســة-

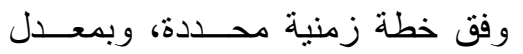

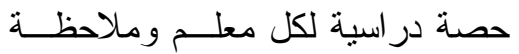

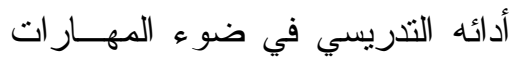
الرئيسة و الفرعية للتنريس المتمــايز فئي و المتضمنة في بطاقة الملاحظة، وذللك خلال الفصل الدراسي الثاني من العام

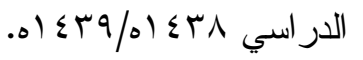




$$
\begin{aligned}
& \text { - معادلة كوبر Cooper). }
\end{aligned}
$$

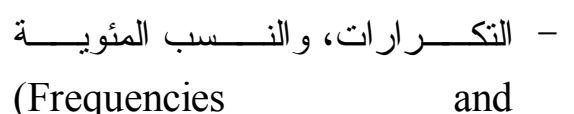

بالنـــــentages)

الملاحظة، وبطاقة المقابلة.

- المتوسط الحسابي (Mean).

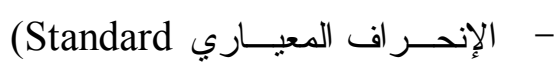

. Deviation)

نتائج الدراسة وتفسيرها ومناقشتها

السؤال الأول: ما المهارات التدريسية

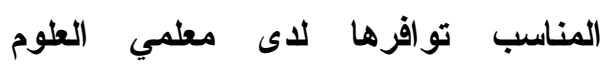

الثرعية بالمرحلة الثانوية في محافظة عفيف في ضوء التدريس المتمايز؟

ولإجابة على هذا السؤال نم إعداد

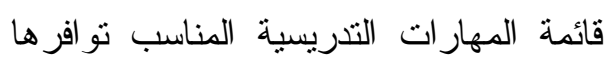
لدى معلمي العلوم الثرعية بالمرحلة الثانوية

$$
\text { في ضوء التنريس المتمايز • }
$$

$$
\begin{aligned}
& \text { المناســبة للأجوبــة ووضـــعها فـي }
\end{aligned}
$$

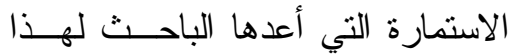

$$
\begin{aligned}
& \text { الغرض (ملحق رقمマ). }
\end{aligned}
$$

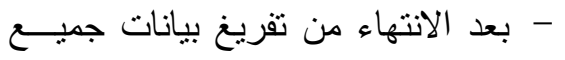

المعلمين في بطاقة المقابلة، تم إدخال

هــذه البيانــات وتحليلهـــا إحــــــئيًا

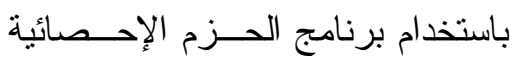

$$
\text { للعلوم الاجتماعية (SPSS). }
$$

ه- الأساليب الإحصائية المستخدمة في الإعلية

في ضوء طبيعـــة الدر اســـة الحاليــة

و أهدافها استخدم الباحث الأساليب الإحصائية

الآتية:

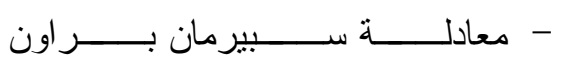

.)(Spearman-Brown

- معادلة ألفا كرونباخ(Cronbach ؛).

\begin{tabular}{|c|c|c|}
\hline عدد المهارات الفرعية & المهارات الرئيسة & م \\
\hline$\varepsilon$ & ممايزة الأهداف & 1 \\
\hline$r$ & ممايزة المحتوى & $r$ \\
\hline 7 & ممايزة الإجر اءات & $r$ \\
\hline$\varepsilon$ & ممايزة مصادر التعلم & $\varepsilon$ \\
\hline 7 & ممايزة التقويم & 0 \\
\hline Tr & الإجمالي & \\
\hline
\end{tabular}

- معامل الارتباط بيرسـون مerson -

.Correlation Coefficient)

جدول (ع - 1) المهارات الرئيسة و الفرعية المتضمنة في قائمة المهارات التذريسية

وفيما يلي يعرض الباحث نتائج نطبيق

السؤال الثاني: ما مستوى الأداء التدريسي الإلي الثعي

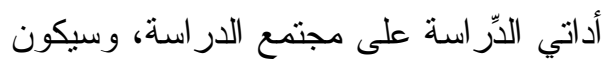

لمعلمي العلوم الثرعية بالمرحلة الثانوية مالية الألئية

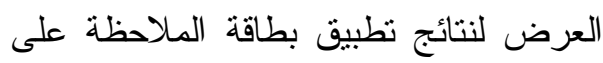

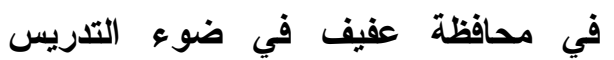

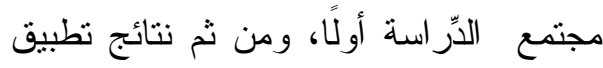

المتمايز ؟

بطاقة المقابلة على نفس المجتمع. 
أولًا: عرض النتائج التي توصلت إليها الدِّراسة من خلال تطبيق بطاقة الملاحظة جدول (ع -r) التكرارات، والنسب المئوية، و المتوسطات الحسابية، و الآحر افات المعيارية، وترتيبها في بطاقة الملاحظة للتحقق من درجة ممارسة أفراد مجتمع الدراسة للمهارات

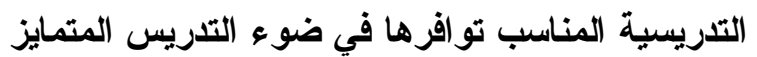

\begin{tabular}{|c|c|c|c|c|c|c|c|c|c|c|}
\hline \multirow[b]{2}{*}{ ترتيب } & \multirow{2}{*}{ الالمعر اف } & \multirow{2}{*}{ الحستوسط } & \multicolumn{5}{|c|}{ درجة الممارسة } & التكرار & \multirow[b]{2}{*}{ المهارات } & \multirow[b]{2}{*}{ p } \\
\hline & & & ضديفة & ضعيفة & متوسطة & كبيرة & كبرًاة & 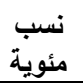 & & \\
\hline & & & & & & & & & \multicolumn{2}{|c|}{ أولًا: مهارة ممايزة المحتوى } \\
\hline \multirow[b]{2}{*}{ r } & \multirow{2}{*}{$1, \cdot 7$} & \multirow{2}{*}{ r, १५ } & 0 & $\wedge$ & 17 & 11 & $r$ & ك5 & يُمايز المعلم بتوسيع & \\
\hline & & & 11,9 & 19, & rᄉ, l & $r\rceil, r$ & $\varepsilon, \wedge$ & $\%$ & عميقة وجديدة. & 1 \\
\hline \multirow{2}{*}{1} & \multirow{2}{*}{$1, .9$} & \multirow{2}{*}{$r, \cdot r$} & 7 & r & Kr & V & $\varepsilon$ & ك ك & \multirow{2}{*}{ المُمنتز المعلم بتركيز } & \multirow{2}{*}{ r } \\
\hline & & & $1 \leqslant, r$ & $\varepsilon, \wedge$ & $0 \varepsilon, \wedge$ & $17, \mathrm{~V}$ & 9,0 & $\%$ & & \\
\hline \multirow{2}{*}{$r$} & \multirow{2}{*}{$1, r_{0}$} & \multirow{2}{*}{$r, \wedge \Lambda$} & v & 9 & $1 \pi$ & $\wedge$ & 0 & ك5 & \multirow{2}{*}{ 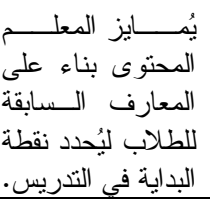 } & \multirow{2}{*}{$r$} \\
\hline & & & 17,8 & $r_{1, \varepsilon}$ & r., & 19, & 11,9 & $\%$ & & \\
\hline & $1,1 \pi$ & $r, 9 \leq$ & \multicolumn{8}{|c|}{ المتوسط الحسابي العام والاتحراف المعياري العام لمهارة ممايزة المحتوى } \\
\hline \multicolumn{11}{|c|}{ ثانيًا: مهارة ممايزة الإجر اءوات } \\
\hline \multirow[t]{2}{*}{$r$} & \multirow{2}{*}{$1, r v$} & \multirow{2}{*}{$r, r)$} & 17 & 11 & 0 & 7 & $\varepsilon$ & ك & \multirow{2}{*}{ 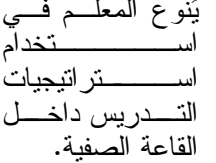 } & \multirow{2}{*}{1} \\
\hline & & & $r \Lambda, 1$ & $r+, r$ & 11,9 & $1 \leqslant, r$ & 9,0 & $\%$ & & \\
\hline \multirow[t]{2}{*}{1} & \multirow[t]{2}{*}{1, ro } & \multirow[t]{2}{*}{$r, 90$} & 7 & 1. & 11 & 1. & 0 & ك & \multirow{2}{*}{ 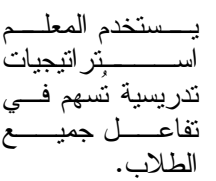 } & \multirow[t]{2}{*}{ r } \\
\hline & & & $1 \varepsilon, r$ & $r r, \Lambda$ & $r \uparrow, r$ & $r$ r, & 11,9 & $\%$ & & \\
\hline \multirow[t]{2}{*}{ r } & $1,1 \mathrm{~V}$ & $r, \Delta r$ & V & $\Lambda$ & 10 & 9 & $r$ & ك & 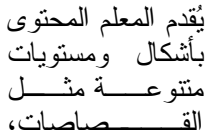 & $r$ \\
\hline & & & $17, V$ & 19, & ro,v & $r_{1}, \varepsilon$ & $v, 1$ & $\%$ & روفونيات، مرئيات، رونات، & \\
\hline & $1, r 4$ & $r, V \cdot$ & & 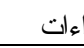 & مايزة الإجر & مهارة & اري الع & ل ت عر اف اله & بط الحسابي العام و الا & \\
\hline & & & & & & & & التطلم & مهارة ممايزة مصادر & \\
\hline 1 & 1) & $r<$ & $\wedge$ & 17 & $1 \pi$ & $r$ & r & ك & 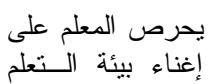 & 1 \\
\hline & & & 19, & rی, & r,. & $v, 1$ & $\varepsilon, \wedge$ & $\%$ & منتوعة. & \\
\hline
\end{tabular}




\begin{tabular}{|c|c|c|c|c|c|c|c|c|c|c|}
\hline \multirow[b]{2}{*}{ ترتيب } & \multirow{2}{*}{ الاتحر افياري } & \multirow{2}{*}{ الحستبي } & \multicolumn{5}{|c|}{ درجة الممارسة } & \multirow{2}{*}{ منئ } & \multirow[b]{2}{*}{ 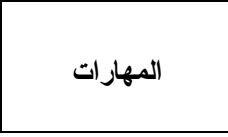 } & \multirow[b]{2}{*}{ م } \\
\hline & & & | غدًا & 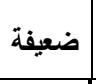 & 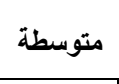 & كبيرة & كبيرة & & & \\
\hline \multirow{3}{*}{ r } & \multirow{2}{*}{$1,1 \mathrm{~V}$} & \multirow{2}{*}{ r, זᄉ } & ir & 9 & ir & v & 1 & ك & \multirow{2}{*}{ 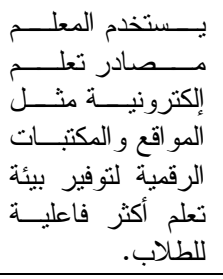 } & \multirow{2}{*}{ r } \\
\hline & & & M, & $r_{1, \varepsilon}$ & $r \wedge, \uparrow$ & $17, \mathrm{~V}$ & r, $\varepsilon$ & $\%$ & & \\
\hline & 1,11 & $r, r q$ & \multicolumn{8}{|c|}{ المتو سط الحسابى العام و الانحر اف المعياري العام لمهارة ممايزة مصادر التعلم } \\
\hline \multicolumn{11}{|c|}{ رابعًا: مهارة ممايزة التقويم } \\
\hline \multirow[t]{2}{*}{1} & \multirow[t]{2}{*}{$1, r 9$} & \multirow[t]{2}{*}{ r,or } & 11 & ir & 9 & 7 & $\varepsilon$ & ك & \multirow{2}{*}{ 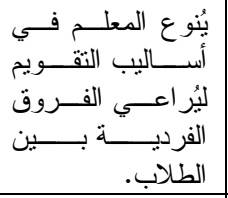 } & \multirow[t]{2}{*}{1} \\
\hline & & & $r \uparrow, r$ & $r \wedge, \uparrow$ & $r_{1}, \varepsilon$ & $1 \leqslant, r$ & 9,0 & $\%$ & & \\
\hline \multirow{4}{*}{ r } & \multirow{2}{*}{$\cdot, 97$} & \multirow{2}{*}{$r, r_{T}$} & $\wedge$ & r. & 11 & 1 & r & ك & \multirow{2}{*}{ 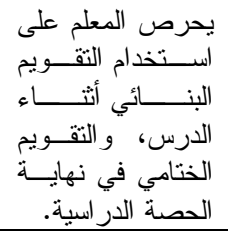 } & \multirow{2}{*}{ r } \\
\hline & & & $19, \cdot$ & $\leqslant \vee, \uparrow$ & $r \uparrow, r$ & $r, \varepsilon$ & $\varepsilon, \wedge$ & $\%$ & & \\
\hline & 1,14 & r, rq & \multicolumn{8}{|c|}{ المتوسط الحسابي العام و الانحر اف المعياري العام لمهارة ممايزة التقويم } \\
\hline & 1,17 & $r, T)$ & \multicolumn{8}{|c|}{ 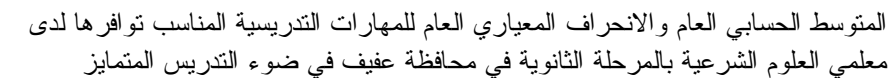 } \\
\hline
\end{tabular}

شكل (ع - 1) المتوسطات الحسابية لتقليرات درجة ممارسة معلمي العلوم الثرعية بالمرحلة الثانوية

للمهارات الأربع الرئيسة المناسب توافرها لايهم في ضوء التدريس المتمايز في بطاقة الملاحظة.

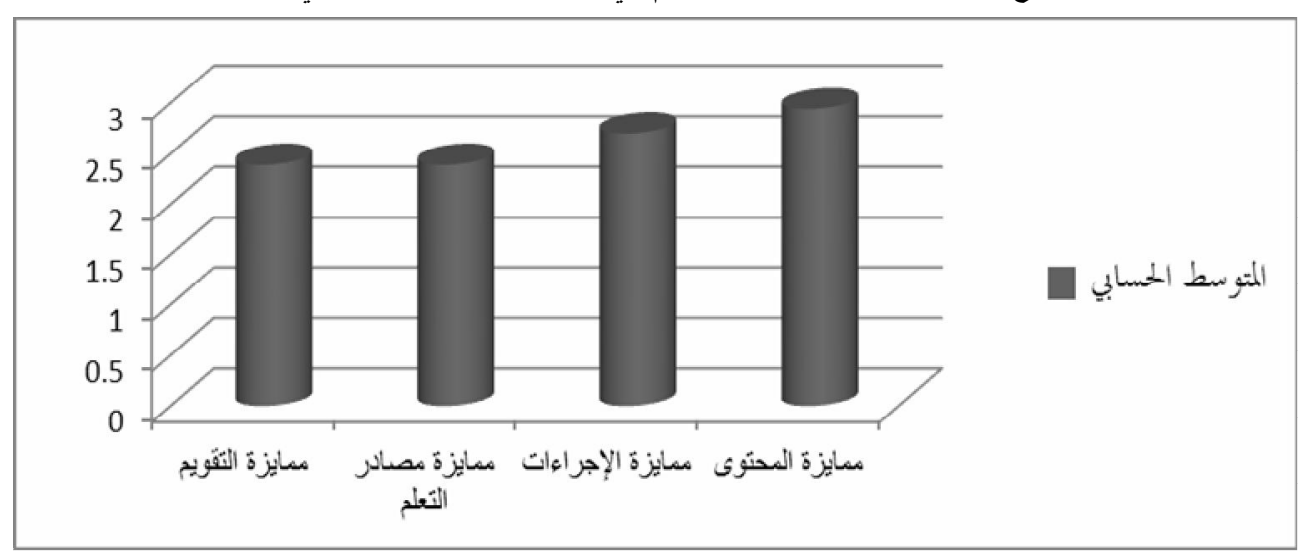

V. \{ 


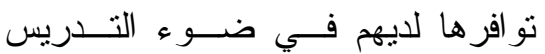

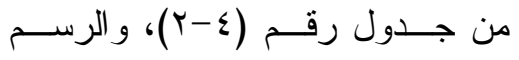

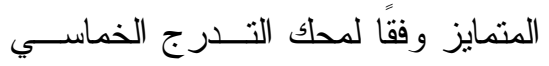

البياني شكل (ع- أ) السابقين يتضح الآتي:

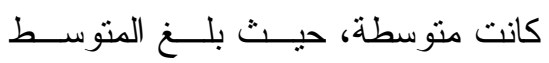

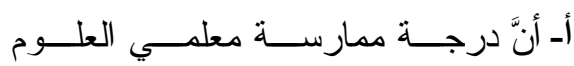

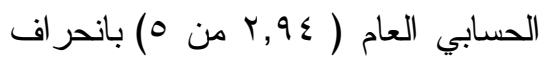

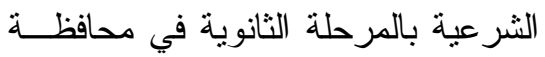

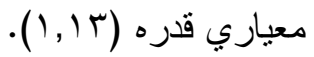

عفيف لمهارة ممايزة المحتوى المناسب

شكل (ع - r) ترتيب درجة ممارسة معلمي العلوم الثرعية بالمرحلة الثانوية في محافظة عفيف للمهار ات الفرعية الممثلة للمهارة الرئيسة (ممايزة المحتوى) في بطاقة الملاحظة

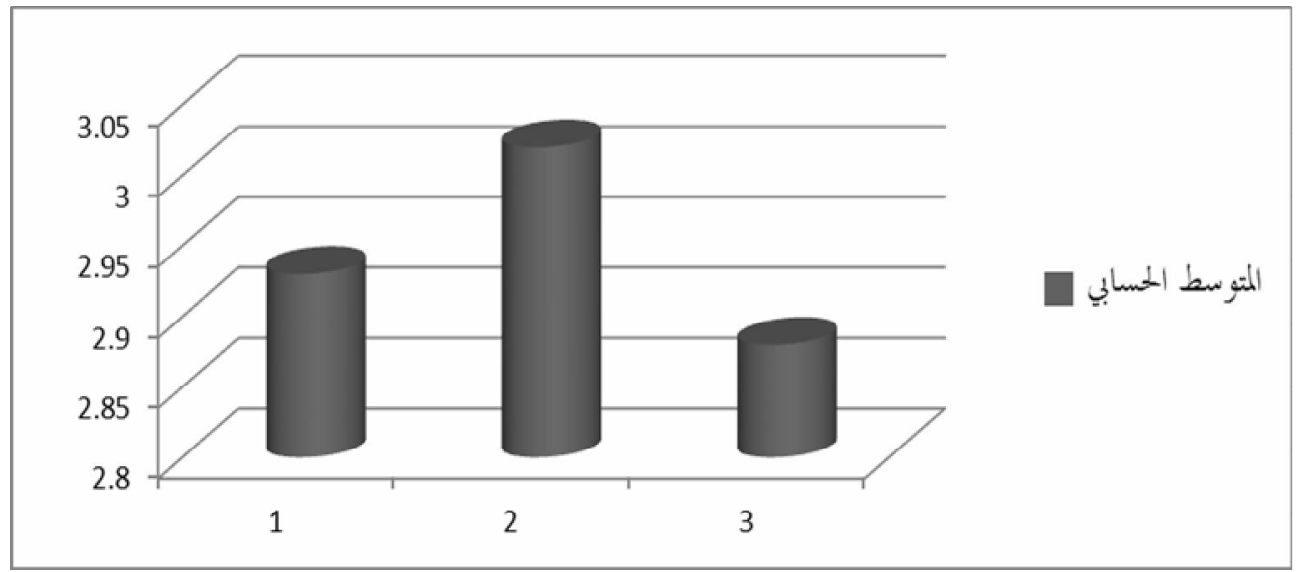

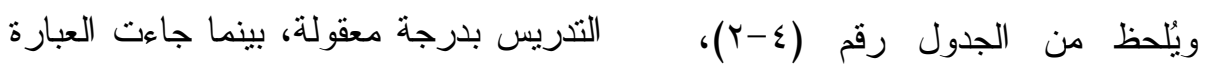

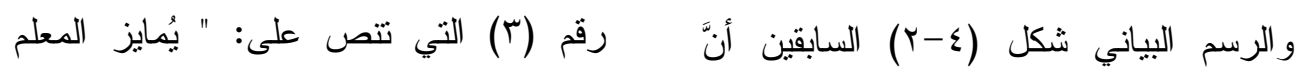

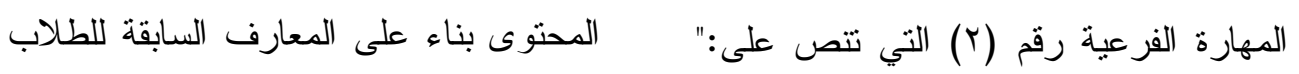

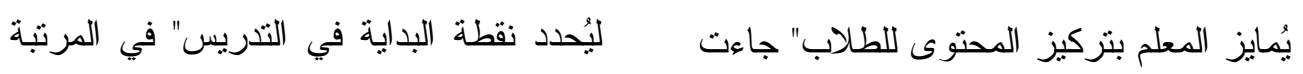

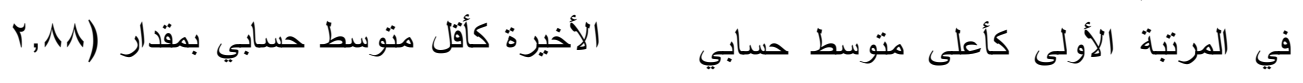

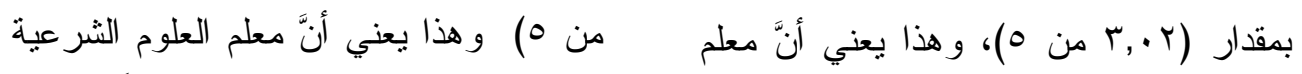

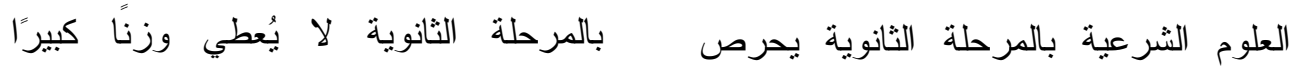

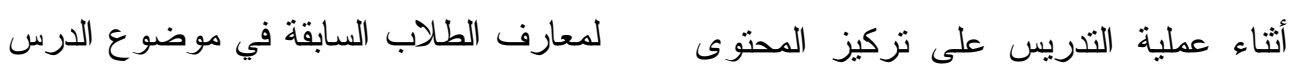

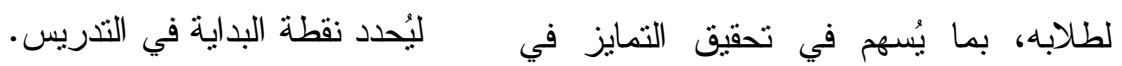


شكل (ع - ب) ترتيب درجة ممارسة معلمي العلوم الثرعية بالمرحلة الثانوية

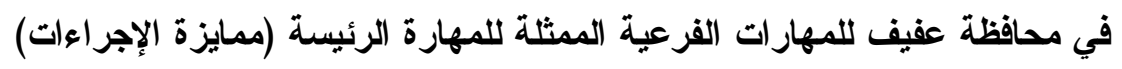

في بطاقة الملاحظة

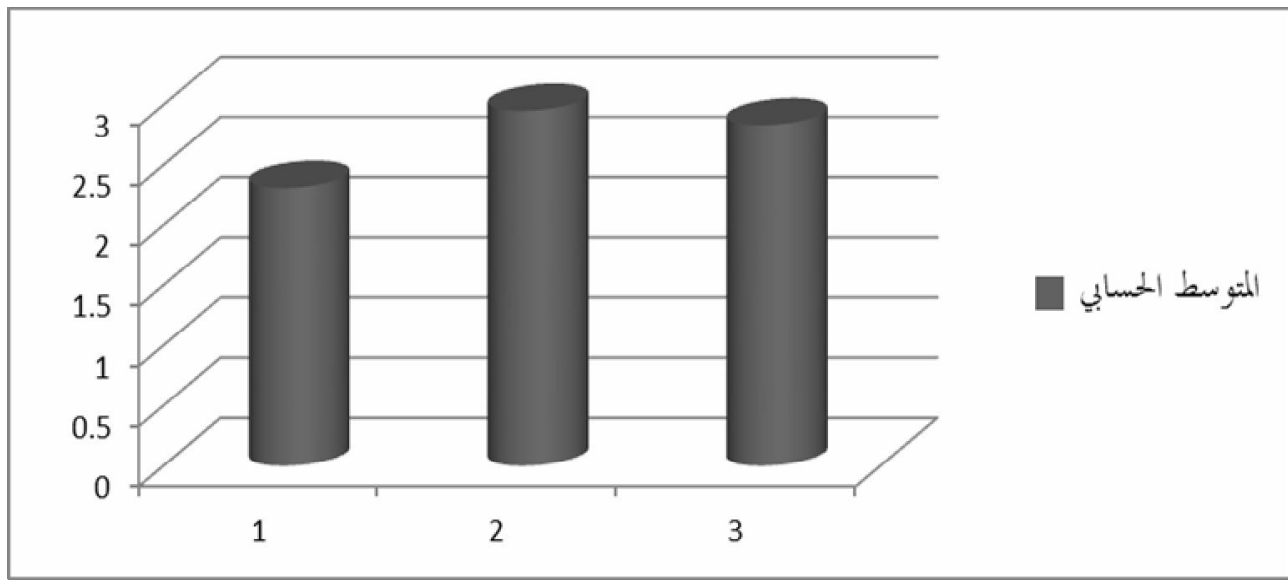

ويُلحظ من الجدول رقم (ع-r)، أن يُسهم في تحقيق التمايز في التدريس

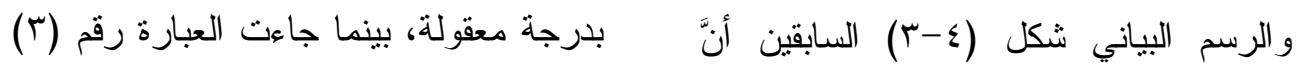

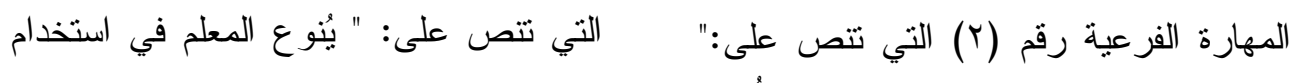

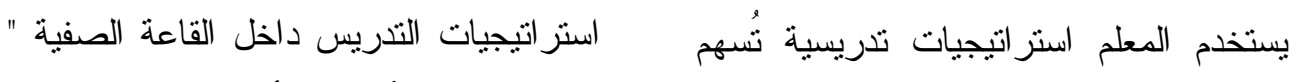

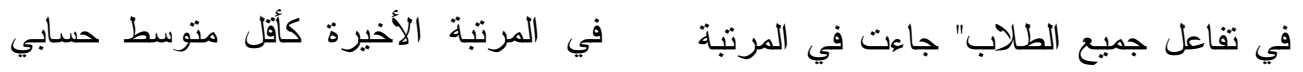

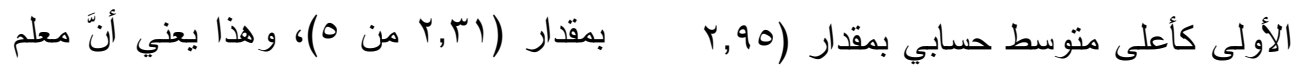

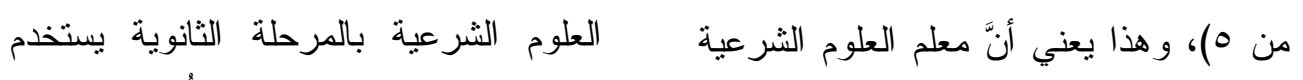

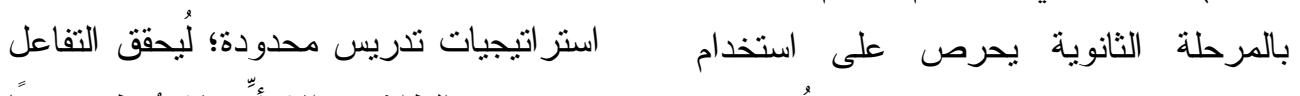

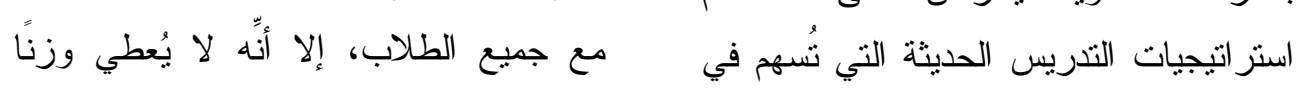

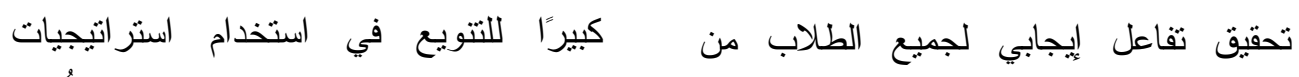

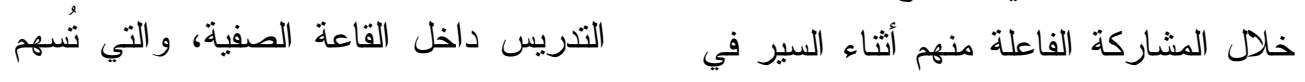
الدرس، سواء تفاعل الطلاب مع بعضهم في تحقيق التمايز في التدريس.

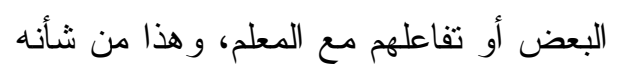


شكل (ع - ؛) ترتيب درجة ممارسة معلمي العلوم الشرعية بالمرحلة الثانوية في

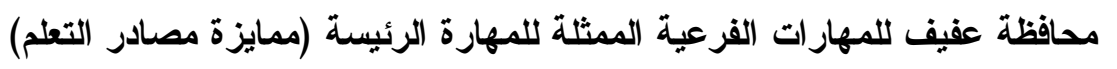
في بطاقة الملاحظة

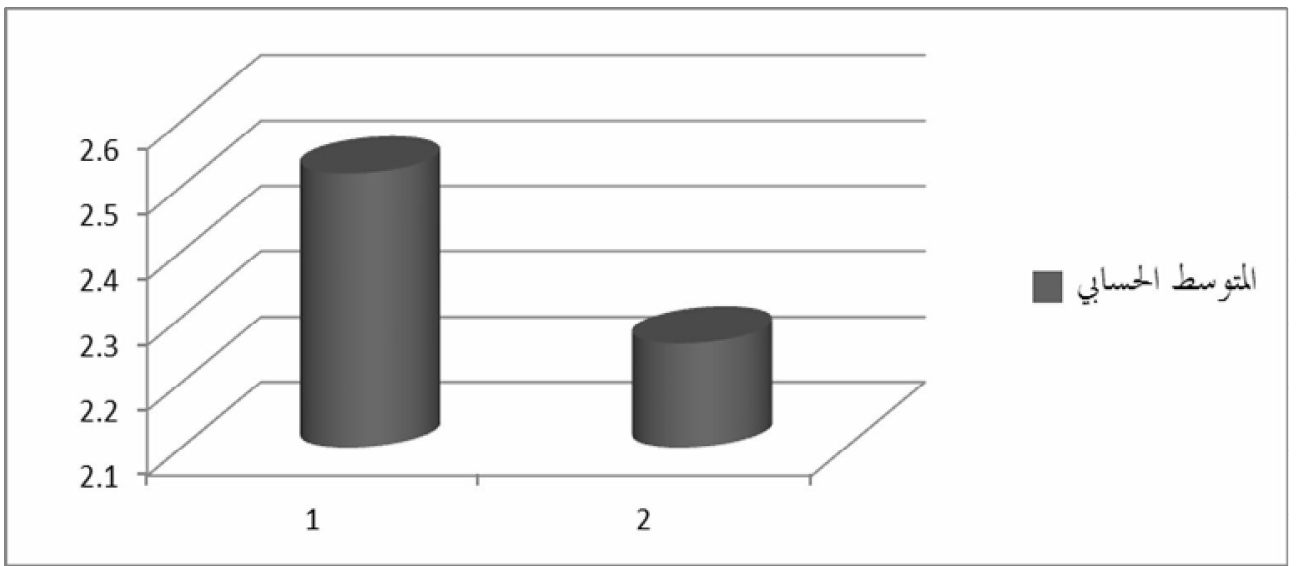

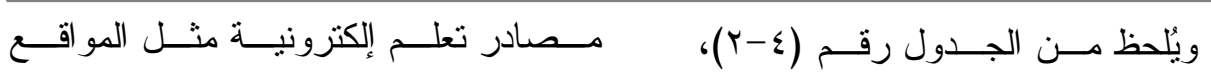

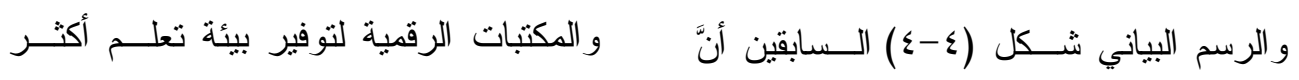

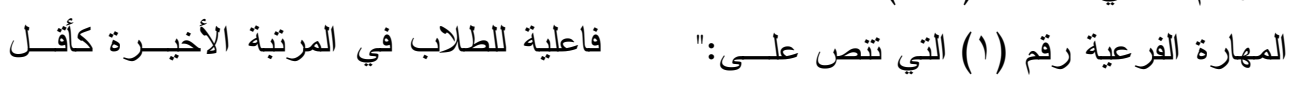

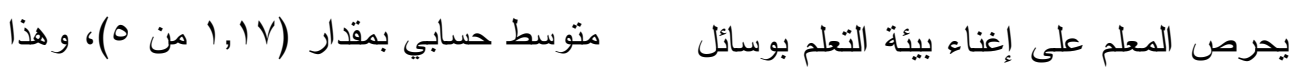

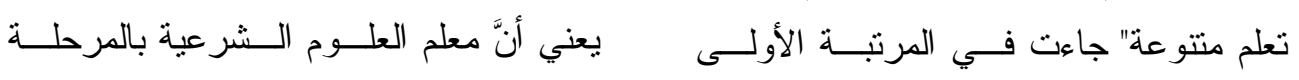

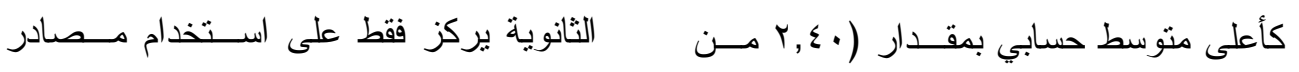

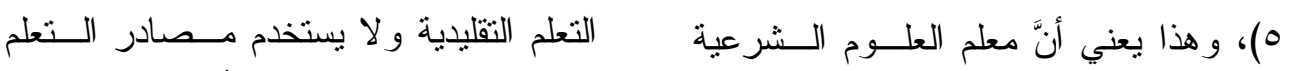

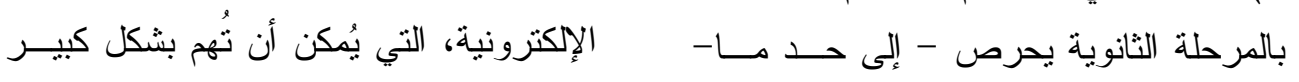

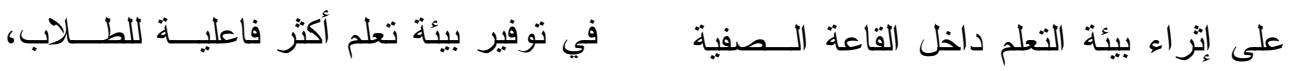

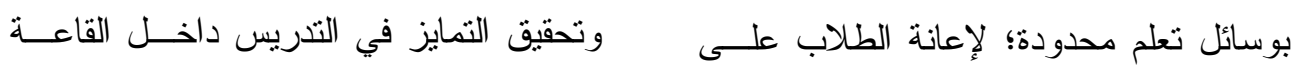
استيعاب محتوى الدرس، بينما جاءت العبارة الصفية. رقم (Y) التي تتص على: " بستخدم المعلـــ 
شكل (ع -ه) ترتيب درجة ممارسة معلمي العلوم الشرعية بالمرحلة الثانوية في محافظة عفيف

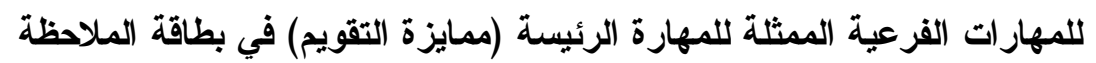

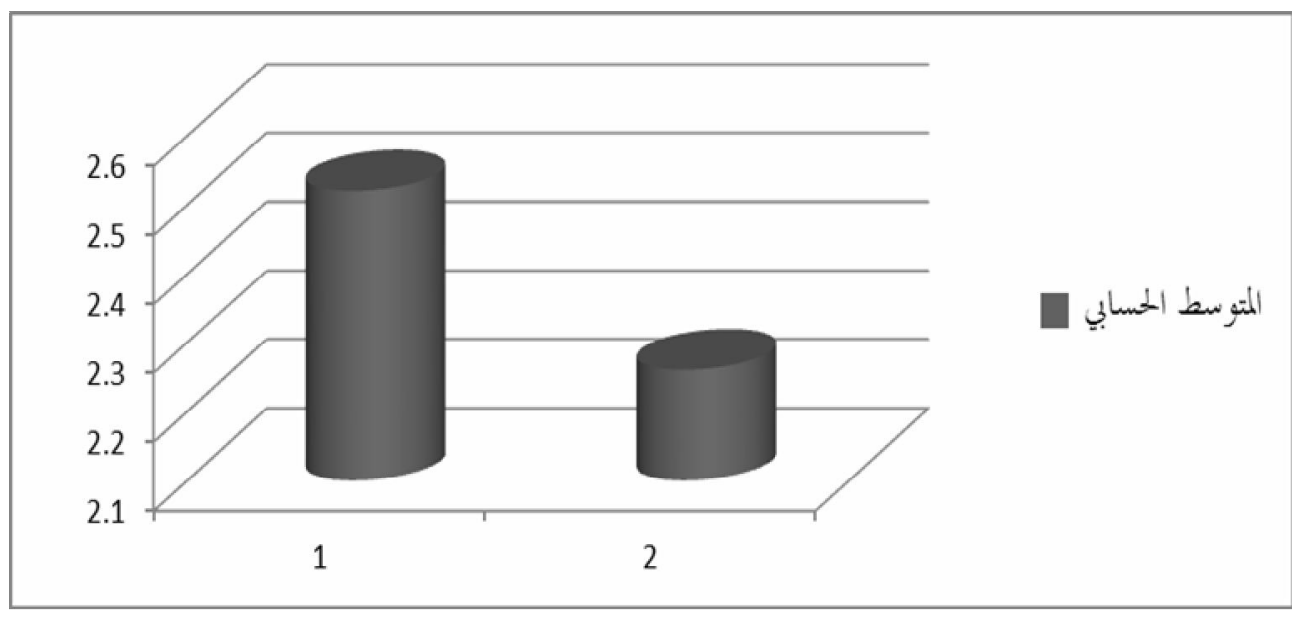

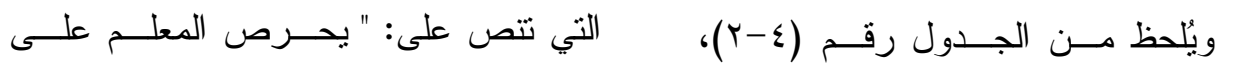

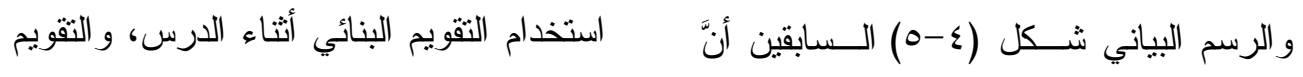

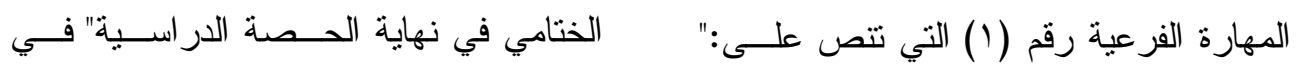

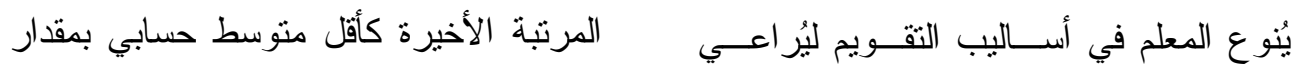

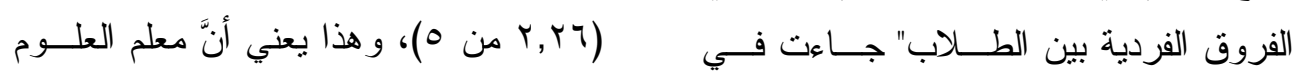

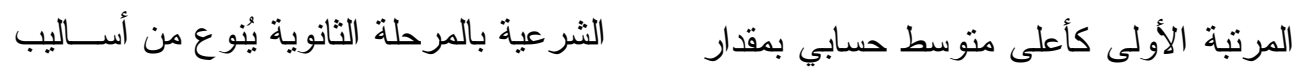

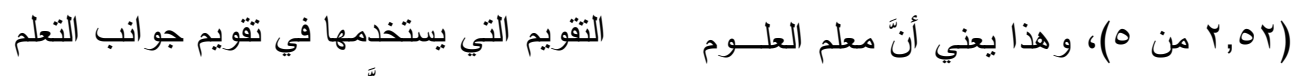

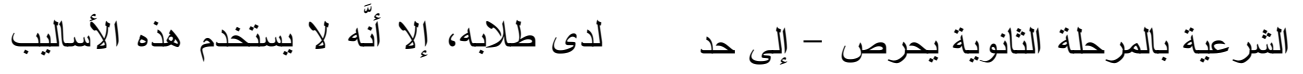

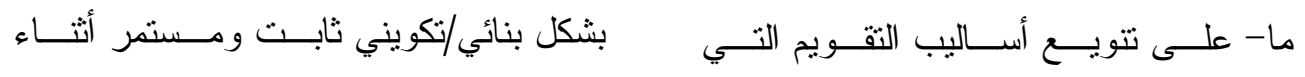

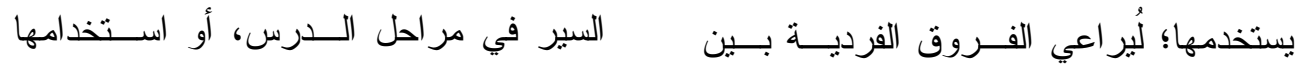

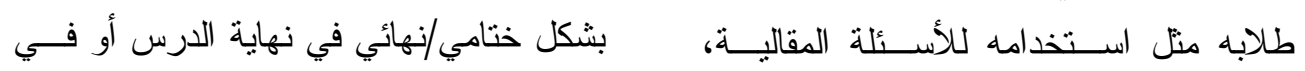
وللأسئلة الموضوعية في تقويم جوانب التعلم نهاية الوحدة الدراسية كاملةً.

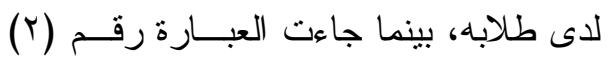


ثانيًا: عرض النتائج التي توصلت إليها الدّرّاسة من خلال تطبيق بطاقة المقابلة

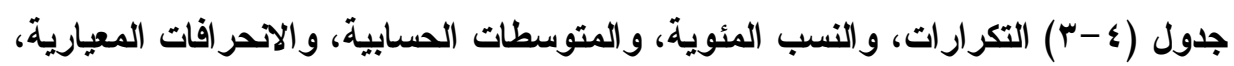
وترتيبها في بطاقة المقابلة للتحقق من درجة ممارسة أفر اد مجتمع الدراسة للمهارات

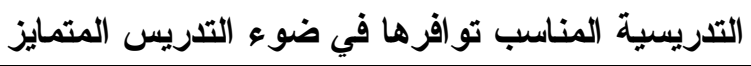

\begin{tabular}{|c|c|c|c|c|c|c|c|c|c|c|}
\hline \multirow[b]{2}{*}{ المهارة } & \multirow[b]{2}{*}{ الالمعراف } & \multirow[b]{2}{*}{ الحستوسطي } & \multicolumn{5}{|c|}{ درجة الممارسة } & \multirow{2}{*}{ نسبر } & \multirow[b]{2}{*}{ المهار ات } & \multirow[b]{2}{*}{ b } \\
\hline & & & ضعيفة & ضعة & متوسطة & كبيرة & كبيرة & & & \\
\hline & & & & & & & & & : مهارة ممايزة الأهداف & \\
\hline \multirow{2}{*}{$r$} & \multirow{2}{*}{$1, r_{0}$} & \multirow{2}{*}{$r, \wedge)$} & 7 & ir & ir & $\circ$ & 7 & 5 & \multirow{2}{*}{ مُعد المعلم أهدافًا متنو عة في } & \multirow{2}{*}{1} \\
\hline & & & $1 \varepsilon, r$ & $r_{1}$, & $r \wedge, T$ & 11,9 & $1 \leq, r$ & $\%$ & & \\
\hline \multirow{2}{*}{$\varepsilon$} & \multirow{2}{*}{ I,rr } & \multirow{2}{*}{$\uparrow, \vee q$} & 9 & 1. & $\wedge$ & 11 & $\varepsilon$ & ك & \multirow{2}{*}{ مُعد المعلم أهدافًا متنو عة في } & \multirow{2}{*}{ r } \\
\hline & & & YI, \{ & $r r, \Lambda$ & $19,$. & Y7, & 9,0 & $\%$ & & \\
\hline \multirow{2}{*}{1} & \multirow{2}{*}{$1, r_{0}$} & \multirow{2}{*}{$r, 90$} & $\circ$ & ir & 11 & $\wedge$ & 7 & ك & \multirow{2}{*}{ 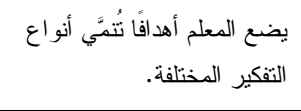 } & \multirow{2}{*}{$r$} \\
\hline & & & 11,9 & $\lceil\wedge, \uparrow$ & $r ד, r$ & 19, & $1 \leq, r$ & $\%$ & & \\
\hline \multirow[b]{2}{*}{$r$} & \multirow[b]{2}{*}{$1, \varepsilon \wedge$} & \multirow[b]{2}{*}{$r, \wedge \wedge$} & 11 & $\wedge$ & $\circ$ & 11 & v & ك & \multirow{2}{*}{ 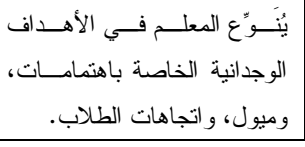 } & \multirow[b]{2}{*}{$\varepsilon$} \\
\hline & & & $Y \nearrow, Y$ & $19, \cdot$ & 11,9 & $r ד, r$ & $17, V$ & $\%$ & & \\
\hline & I, I & r,^ঙ & \multicolumn{8}{|c|}{ المتوسط الحسابي العام و الانحر اف المعياري العام لمهارة ممايزة الأهداف } \\
\hline \multicolumn{11}{|c|}{ ثانيًا: مهارة ممايزة الإجراءات } \\
\hline & & & 17 & v & 7 & 7 & v & ك & من يُكلف المعلم الطلاب بعدد محدد & \\
\hline & & & $r \wedge, 1$ & 17,8 & $1 \varepsilon, r$ & $1 \leq, r$ & $17, V$ & $\%$ & و مشكـــل مــــرو عات، وحـــل & \\
\hline r & $1, r \leq$ & $r, \uparrow$. & 1. & $1 \varepsilon$ & 7 & v & 0 & ك & يضع المعلــم أنـشطة متعــددة & $r$ \\
\hline & & & $r r, \Lambda$ & ( & $1 \varepsilon, r$ & $17, V$ & 11,9 & $\%$ & التحدي. & \\
\hline 1 & $1, r V$ & r,V $q$ & 9 & 11 & $\wedge$ & $\wedge$ & 7 & ك & يضع المعلــم أنـشطة تعليميــة & $r$ \\
\hline & & & $r 1, \varepsilon$ & rד, & 19 & 19 & $1 \leqslant, r$ & $\%$ & الدر اسي. & \\
\hline & $1, \leqslant 1$ & $r, 70$ & & & & &. & . & سط الحسابي العام و الانحر اف الد & \\
\hline
\end{tabular}




\begin{tabular}{|c|c|c|c|c|c|c|c|c|c|c|}
\hline \multirow[b]{2}{*}{ ت المهارة } & \multirow[b]{2}{*}{ المعياري } & \multirow[b]{2}{*}{ المسابي } & \multicolumn{5}{|c|}{ درجة الممارسة } & \multirow{2}{*}{ مئكرار } & \multirow[b]{2}{*}{ 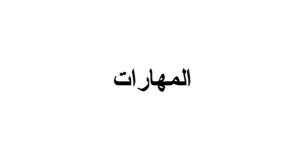 } & \multirow[b]{2}{*}{ b } \\
\hline & & & ضعدًا & ضعة في & 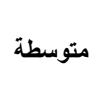 & 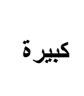 & كبيرة & & & \\
\hline \multicolumn{11}{|c|}{ ثالثًا: مهارة ممايزة مصادر التعلم } \\
\hline \multirow{2}{*}{1} & \multirow{2}{*}{$1,1,4$} & \multirow{2}{*}{ r, . . } & Ir & 1. & V & 9 & $\varepsilon$ & s & \multirow{2}{*}{ 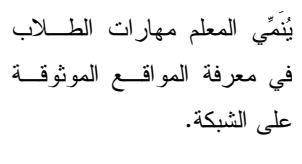 } & \multirow{2}{*}{1} \\
\hline & & & $r \wedge, T$ & $r r, \Lambda$ & $17, \mathrm{~V}$ & $r_{1}, \varepsilon$ & 9,0 & $\%$ & & \\
\hline \multirow{3}{*}{ r } & \multirow{2}{*}{$1, \cdot \varepsilon$} & \multirow{2}{*}{$r, r^{\top}$} & 1. & 11 & $\wedge$ & 。 & 1 & ك & \multirow{2}{*}{ 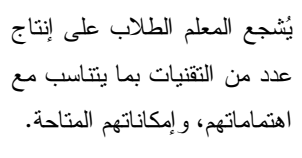 } & \multirow{2}{*}{ r } \\
\hline & & & $r r, \Lambda$ & $\leqslant r, q$ & $19,$. & 11,9 & $r, \varepsilon$ & $\%$ & & \\
\hline & l,r. & $r, \varepsilon r$ & \multicolumn{8}{|c|}{ المتوسط الحسابي العام والانحر اف المعياري العام لمهارة ممايزة مصادر التعلم } \\
\hline \multicolumn{11}{|c|}{ رابعًا: مهارة ممايزة التقويم } \\
\hline \multirow[t]{2}{*}{$r$} & \multirow{2}{*}{ I, rV } & \multirow{2}{*}{ r, } & 1. & Kr & $\wedge$ & 9 & $r$ & ك & \multirow{2}{*}{ 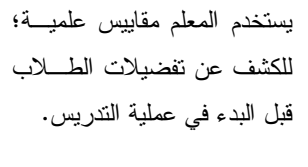 } & \multirow{2}{*}{1} \\
\hline & & & $r r, \Lambda$ & $Y \wedge, T$ & $19,$. & $r_{1, \varepsilon}$ & $v, 1$ & $\%$ & & \\
\hline \multirow{2}{*}{1} & \multirow{2}{*}{$1, \leq 7$} & \multirow{2}{*}{$r, \imath \varepsilon$} & $1 \pi$ & $\wedge$ & 9 & 。 & V & ك & \multirow{2}{*}{ 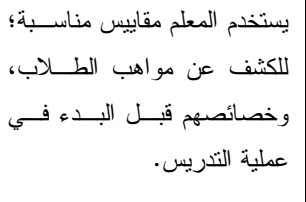 } & \multirow{2}{*}{ r } \\
\hline & & & $r, \cdot$ & $19,$. & $r_{1, \varepsilon}$ & 11,9 & $17, \mathrm{~V}$ & $\%$ & & \\
\hline \multirow{2}{*}{$r$} & \multirow{2}{*}{$1, \leqslant 0$} & \multirow{2}{*}{$r, 0}$. & 10 & $\wedge$ & $\wedge$ & 。 & 7 & ك & \multirow{2}{*}{ 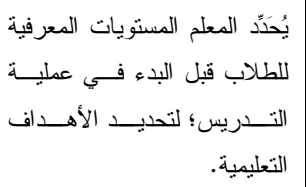 } & \\
\hline & & & $r_{0, v}$ & $19,$. & $19,$. & 11,9 & $1 \varepsilon, r$ & $\%$ & & \\
\hline & & & IT & $\pi$ & $\wedge$ & 0 & $\varepsilon$ & ك & 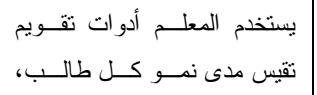 & \\
\hline & & & $\curlyvee \wedge, \uparrow$ & r & 19 & 11,9 & 9,0 & $\%$ & 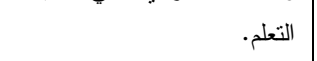 & \\
\hline & $1, r v$ & $r, 0 \leqslant$ & & & & 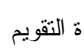 & 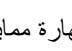 & 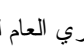 & ل ـ سطط الحسابي العام و الانحر اف المعي & \\
\hline & 1, & $r, T r$ & 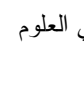 & 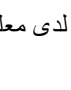 & 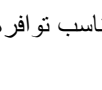 & 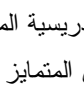 & 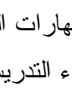 & 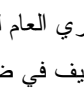 & 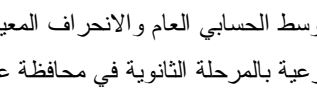 & \\
\hline
\end{tabular}


شكل (؟ - ؟) المتوسطات الحسابية لتقديرات درجة ممارسة معلمي العلوم الثرعية بالمرحلة الثانوية

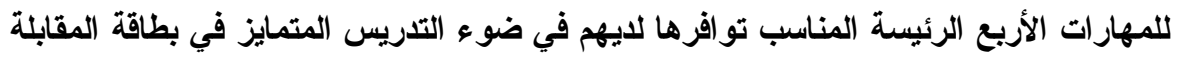

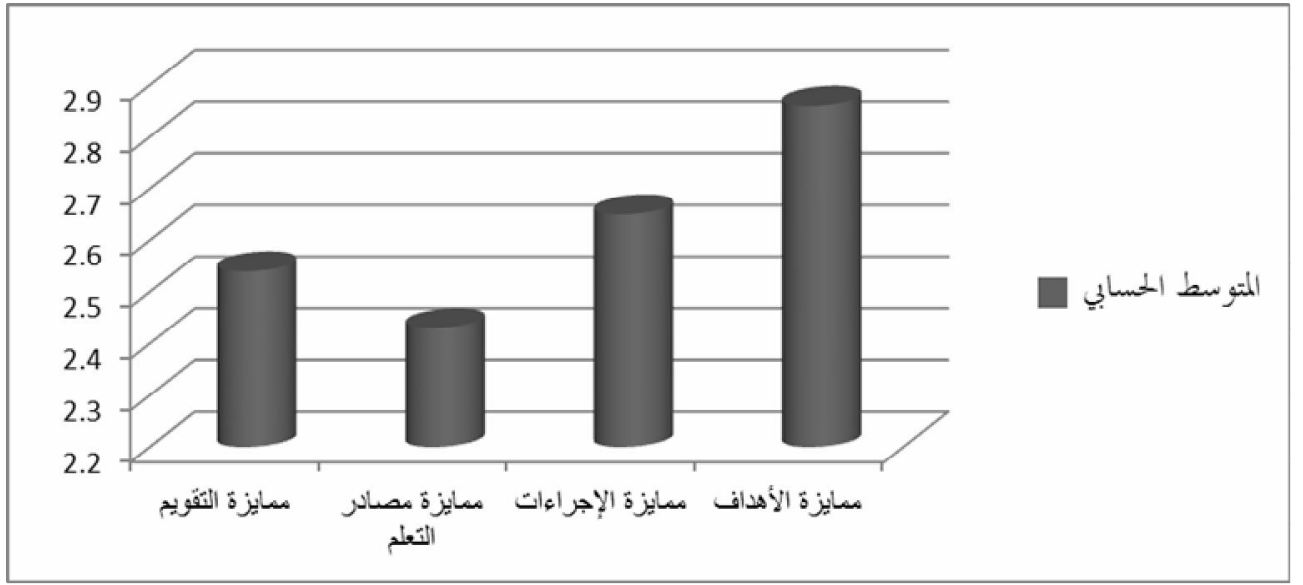

من جدول رقم (؟-7))، و الرسم البياني الخماسي كانت متوسطة، حيث بلغ المنتوسط

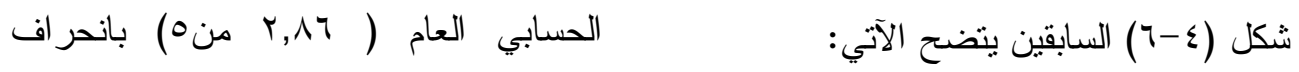

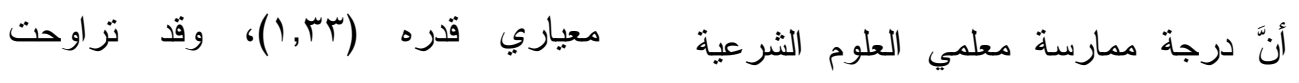

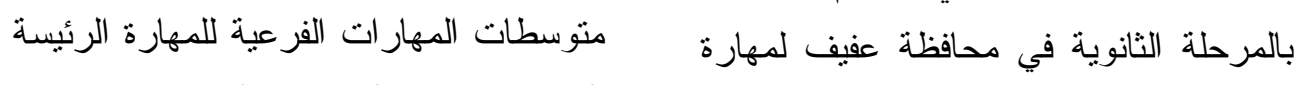

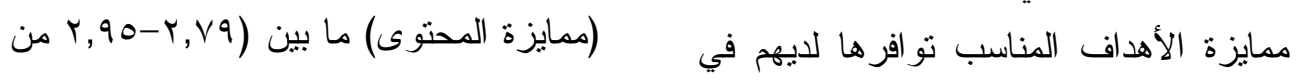

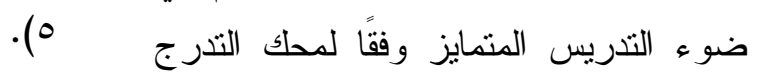

شكل (ع ا V-) ترتيب درجة ممارسة معلمي العلوم الثرعية بالمرحلة الثانوية في محافظة عفيف للمهارات الفرعية الممثلة للمهارة الرئيسة (ممايزة الأهداف) في بطاقة دماتة المقابلة

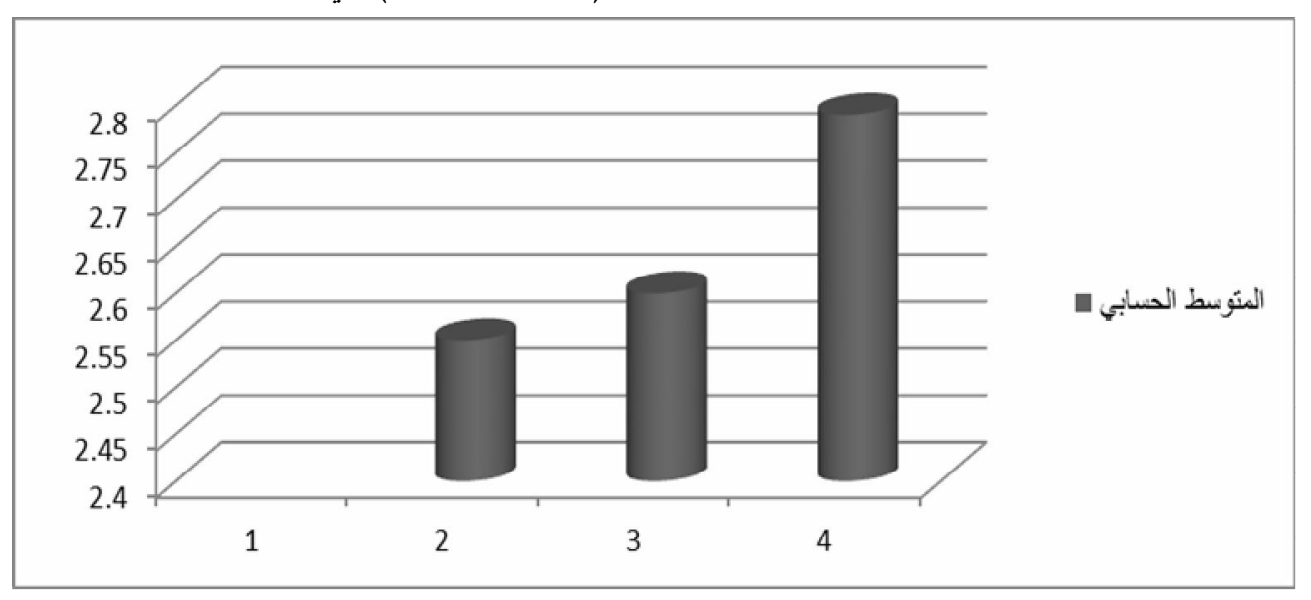


نظرًا لمناسبة طبيعة هذه الأنماط من التفكير

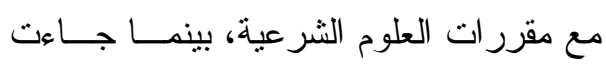

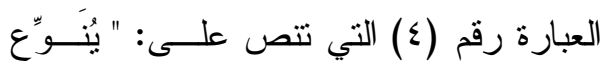

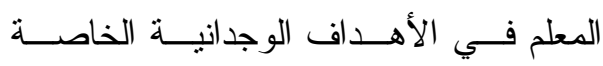
باهنمامات، وميول، و اتجاهات الطلاب" فـي لـي لـاهي

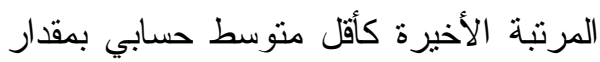

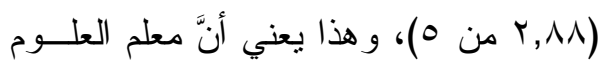

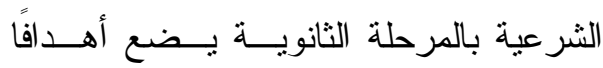

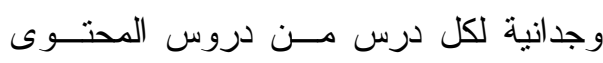

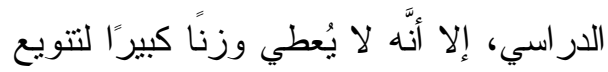

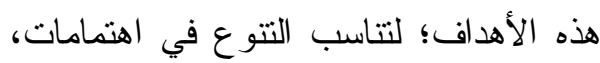

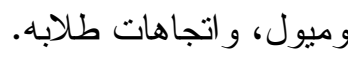

ويُلحظ مــن الجـدول رقـم (ع-ب)،

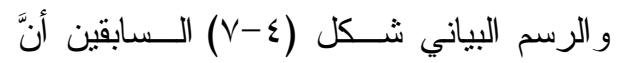

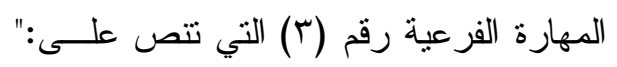

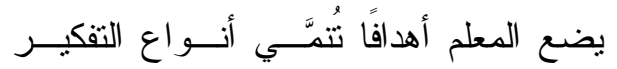

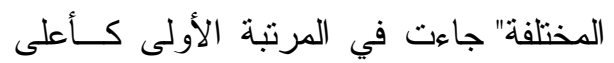

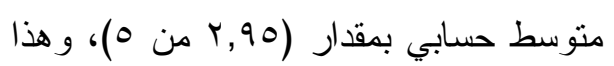

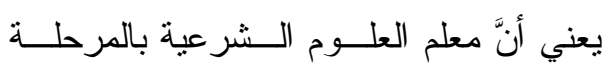

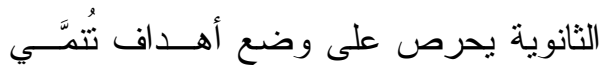

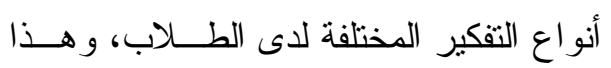
تبين من تحليل دفاتر إعداد الدروس الخاصة الفيل بالمعلمين، كما تبين من مقــابلتهم أن أبـــرز

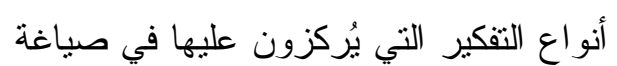
الأهداف التفكير الناقد و التفكير الاســتـلالي

أ- شكل (ع-1) ترتيب درجة ممارسة معلمي العلوم الثرعية بالمرحلة الثانوية في محافظة عفيف للمهارات الفرعية الممثلة للمهارة الرئيسة (ممايزة الإجراءات) في بطاقة المقابلة

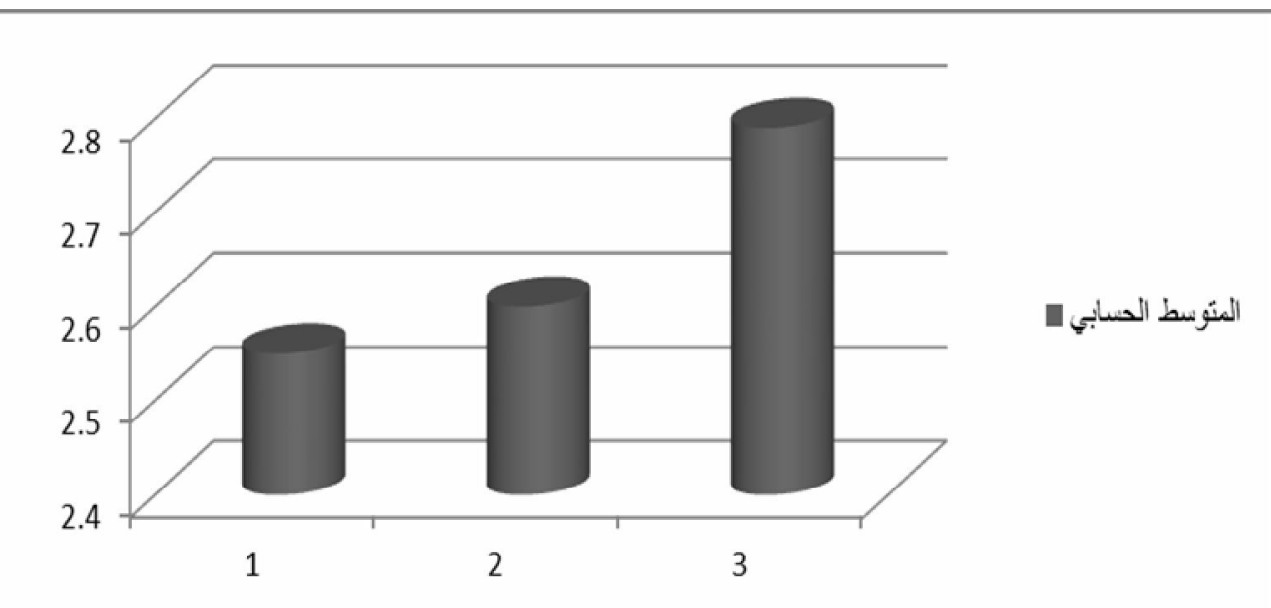

ويُلحظ من الجدول رقم (ع-ب)، يضع المعلم أنشطة تعليمية منمايزة حسب

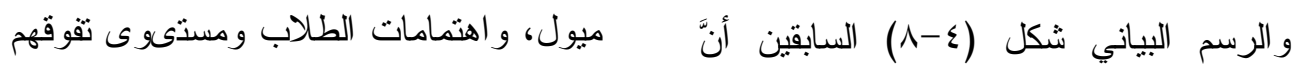

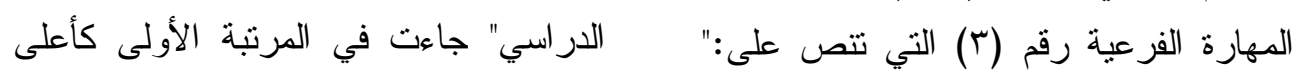


منوسط حسابي بمقدار (r,V9 من 0) و هذا وتختلف هذه النتيجة مع دراسة الغامدي

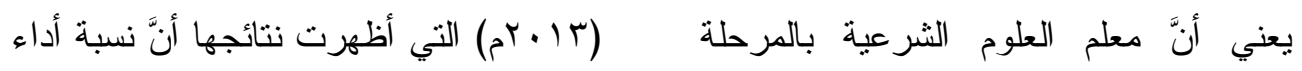

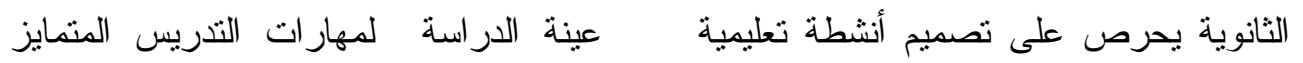

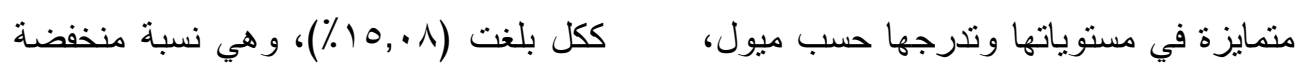
و اهتمامات طلابه، ومسنوى تقوقهم الدر اسي جدًا.

شكل (ع - 9) ترتيب درجة ممارسة معلمي العلوم الثرعية بالمرحلة الثانوية

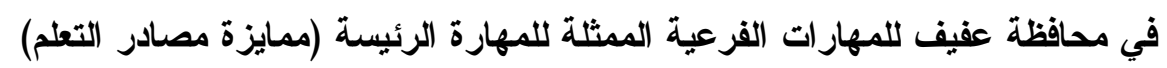
في بطاقة المقابلة

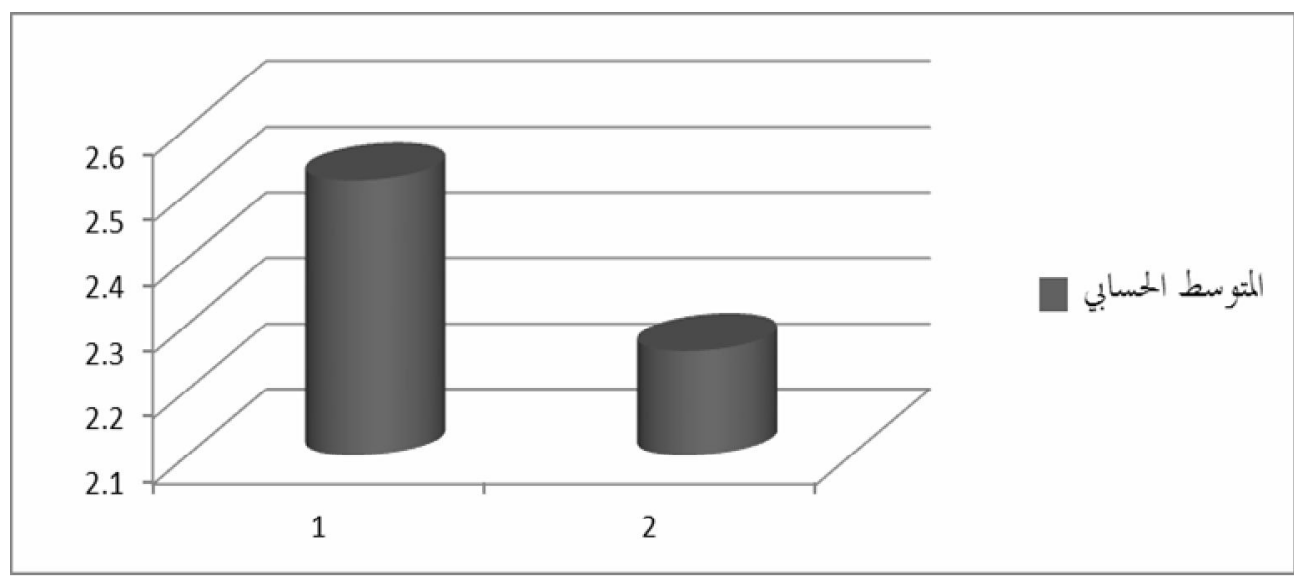

ويُلحظ من الجدول رقم (ع-ب)، المواقع الموثوقة على شبكة الإنترنت، حيث

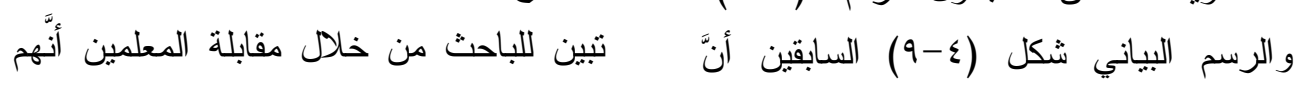

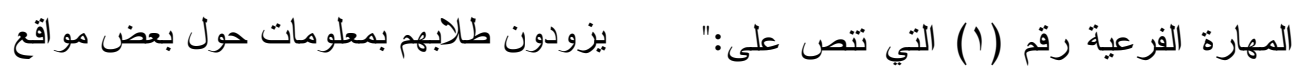

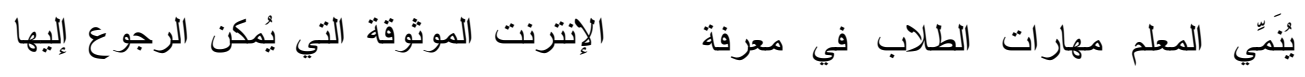

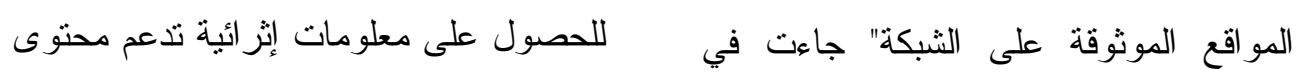

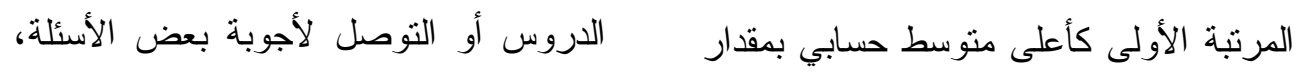

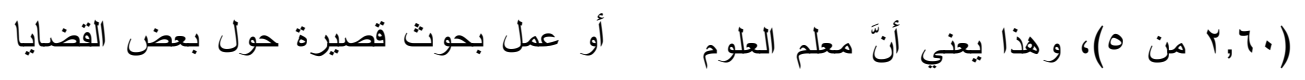

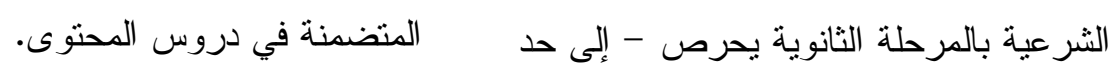

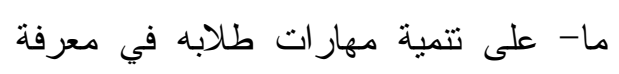


شكل (ع - • 1) ترتيب درجة ممارسة معلمي العلوم الثرعية بالمرحلة الثانوية في محافظة

عفيف للمهارات الفرعية المثلة للمهارة الرئيسة (ممايزة التقويم) في بطاقة المقابلة

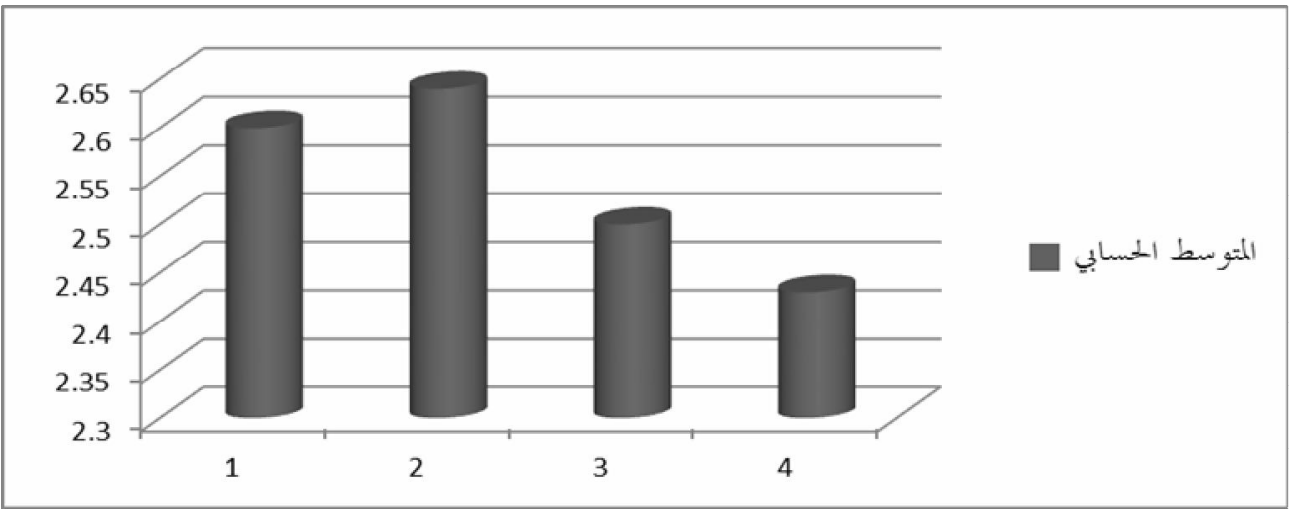

ويُلحظ من الجدول رقم (ع-r)، التنريس، و إن كانت هذه المقاييس من وجهة

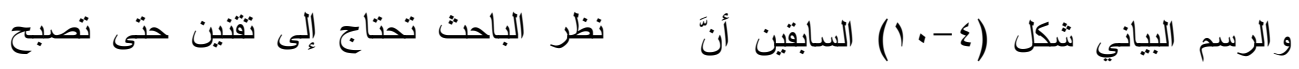
المهارة الفرعية رقم (r) التي تتص على:" أكثر مناسبة؛ لتحقيق الهدف منها.

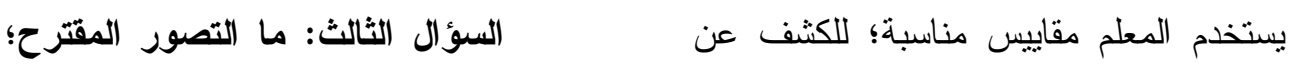

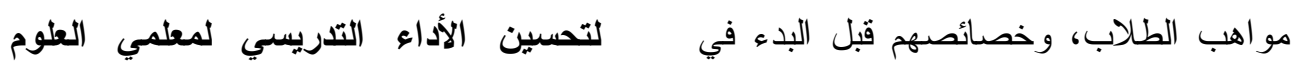

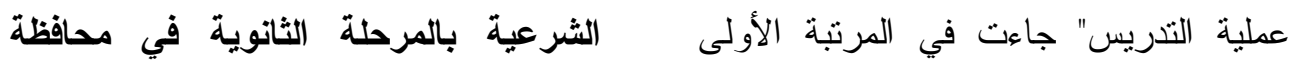
كأعلى منتوسط حسابي بمقدار ( (

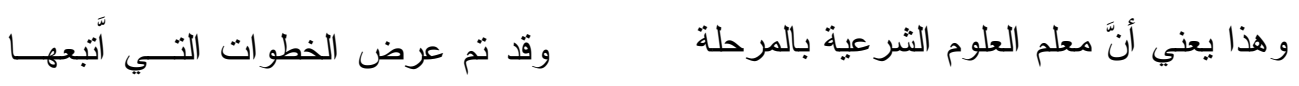

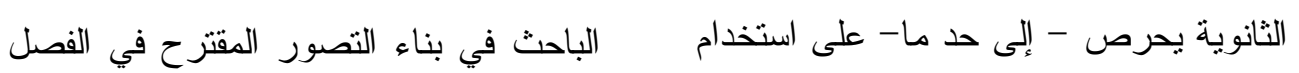
بعض المقاييس المقننة؛ للكثف عن مواهب الثالث من هذه الدراسة، وقد اشتمل التصور

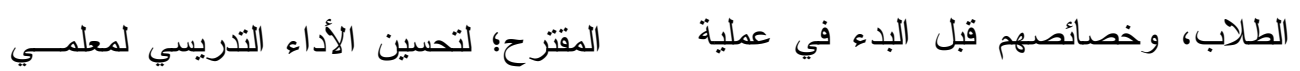

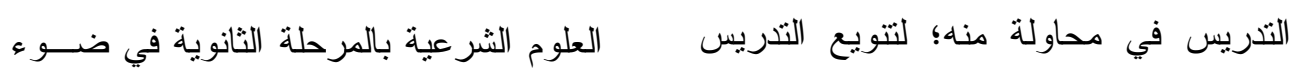

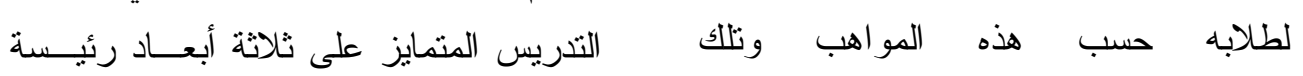

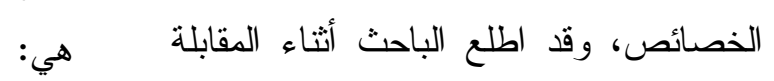
مع المعلمين على نماذج من المقاييس التي أ- بـ برامج إعداد معلمي العلوم الـشرعية

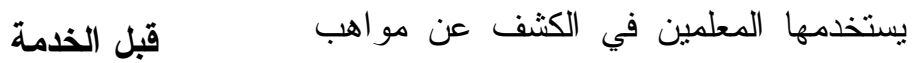
وخصائص طلابهم قبل البدء في فئ عملية 


$$
\text { منها بوسائل ومصادر التعلم. }
$$
- التقليل من الأعباء الإدارية الملقاة علــى

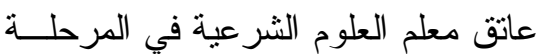
الثانوية؛ لكي يتسنى له تتفيذ التـدريس المتمايز في الصف الدراسي. - نوفير المكافآت، والحــوافز التـشيعية

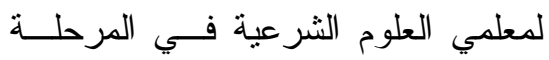
الثانوية في ضوء التدريس المتمايز على نحو يحقق الأهداف المرجوة منه.

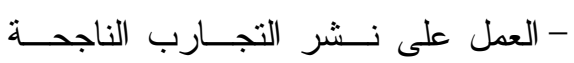

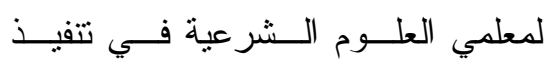

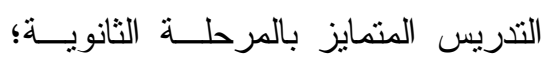
حتى يتسنى لمعلمين آخــرين الاســتفادة منها. جـ- برنـــامـج تــدريبي لمعلمــي العلــوم الثرعية في المرحلة الثانوية

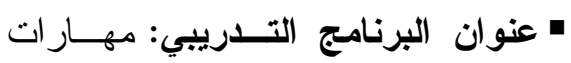
التدريس المتمايز - الهذف العام للبرنامج التّريبي: يهذف البرنامج التدريبي إلى إكــساب معلمــي لهـي

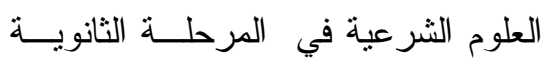

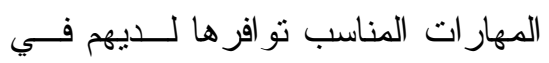
ضوء التدريس المتمايز .

\section{- الأهداف التفصيلية للبرنامج التدريبي:} - إكساب معلمي العلــوم الــشرعية فـي المرحلة الثانوية مهارة ممايزة الأهداف.
حيث تتطلب بر امج إعداد معلمي العلــوم

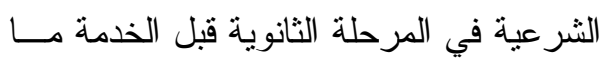

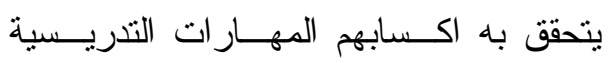
المناسب تو افرها لديهم في ضوء التهـدريس

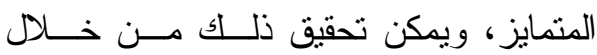
تضمين المهار ات التدريسية المناسب نو افرها لاى معلمي العلوم الـشرعية فــي ضــــو التنريس المتمايز في المقــررات الدراســية التي تُقدّم لهم في أثثاء فترة إعدادهم بالكلية،

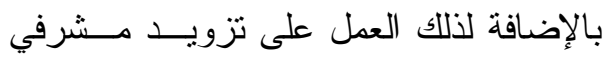

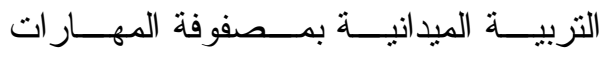
التدريسية المناسب تو افرها لدى معلم العلوم الثرعية في ضوء التدريس المتمايز . ب- القائمون على تدريس العلوم الثرعية بإدارة التعليم في محافظة عفيف

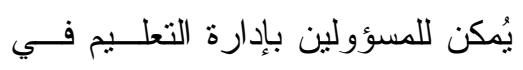
محافظة عفيف القيام بعدة إجر اءات من شأنها بأنا أن تُسهم في اكساب معلمي العلوم الــشر عية

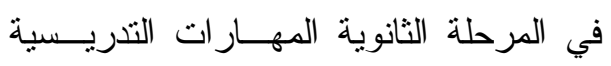
المناسب نو افرها لديهم في ضو هـ التــدريس المتمايز ، ومن بين هذه الإجر اءات ما يلي: - العمل على تذليل الصعوبات التي تواجه

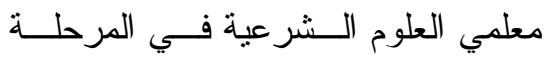
الثانوية في تتفيذ التدريس المتمايز .

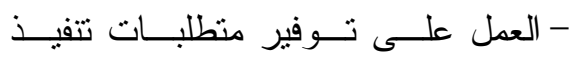
التدريس المتمايز في الصفوف الدراسية بالمرحلة الثانوية، وبخاصة مـــا يتعلـقن 
- الفئة المستهدفة من البرنامج التــدريبي: معلمي العلوم الثرعية في المرحلة الثانوية بإدارة التعليم في محافظة عفيف. معلم • الخطة الزمنية لتنفيذ البرنامج التدريبي: يقتر ح الباحث إجمالي ســاعات البرنـــامج

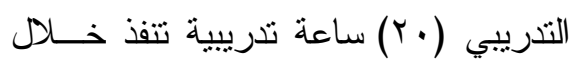

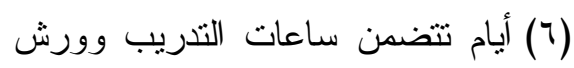

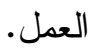

$$
\text { • وحدات البرنامج التدريبي }
$$

يتضمن البرنامج التدريبي خمس وحدات تدريبية، بحيث تشتمل كل وحدة منها علــى لـى

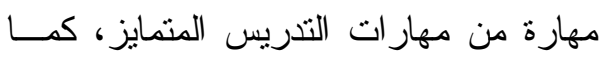

$$
\text { هو مُوضح في الجدول الآتي: }
$$

جدول (؛ - ؛ ) محتوى البرنامج التريبي المقترح لمعلمي العلوم الشرعية في المرحلة

\begin{tabular}{|c|c|c|c|c|}
\hline \multicolumn{5}{|c|}{ الثانوية والخطة الزمنية له } \\
\hline عدد الأيام & عدد ساعات ورش العمل & عدد ساعات التدريب & الوحدات التدريبية & b \\
\hline 1 & 1 & r & ممايزة الأهداف & 1 \\
\hline 1 & 1 & r & ممايزة المحتوى & r \\
\hline 1 & 1 & r & ممايزة الإجر اءات & r \\
\hline 1 & 1 & r & ممايزة مصادر التعلم & $\varepsilon$ \\
\hline r & 1 & $\varepsilon$ & ممايزة الثقويم & $\circ$ \\
\hline 7 & 0 & 10 & 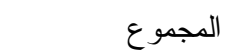 & \\
\hline
\end{tabular}
الثانوية و الخطة الزمنية له
- إكساب معلمي العلــوم الــشرعية فـي

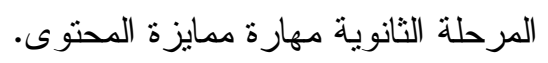

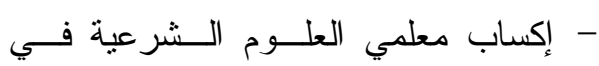

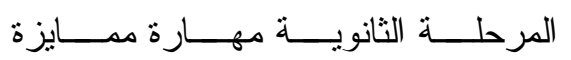

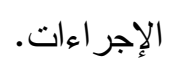

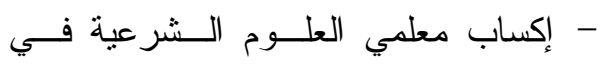

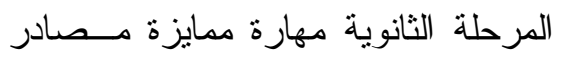

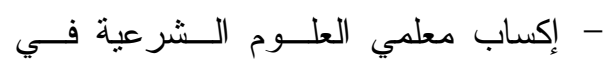

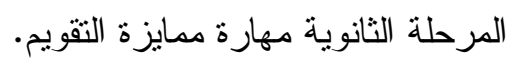


شكل (ع - r I) أبعاد التصور المقترح؛ لتحسين الأداء التدريسي لمعلمي العلوم الشرعية بالمرحلة الثانوية في ضوء التدريس المتمايز

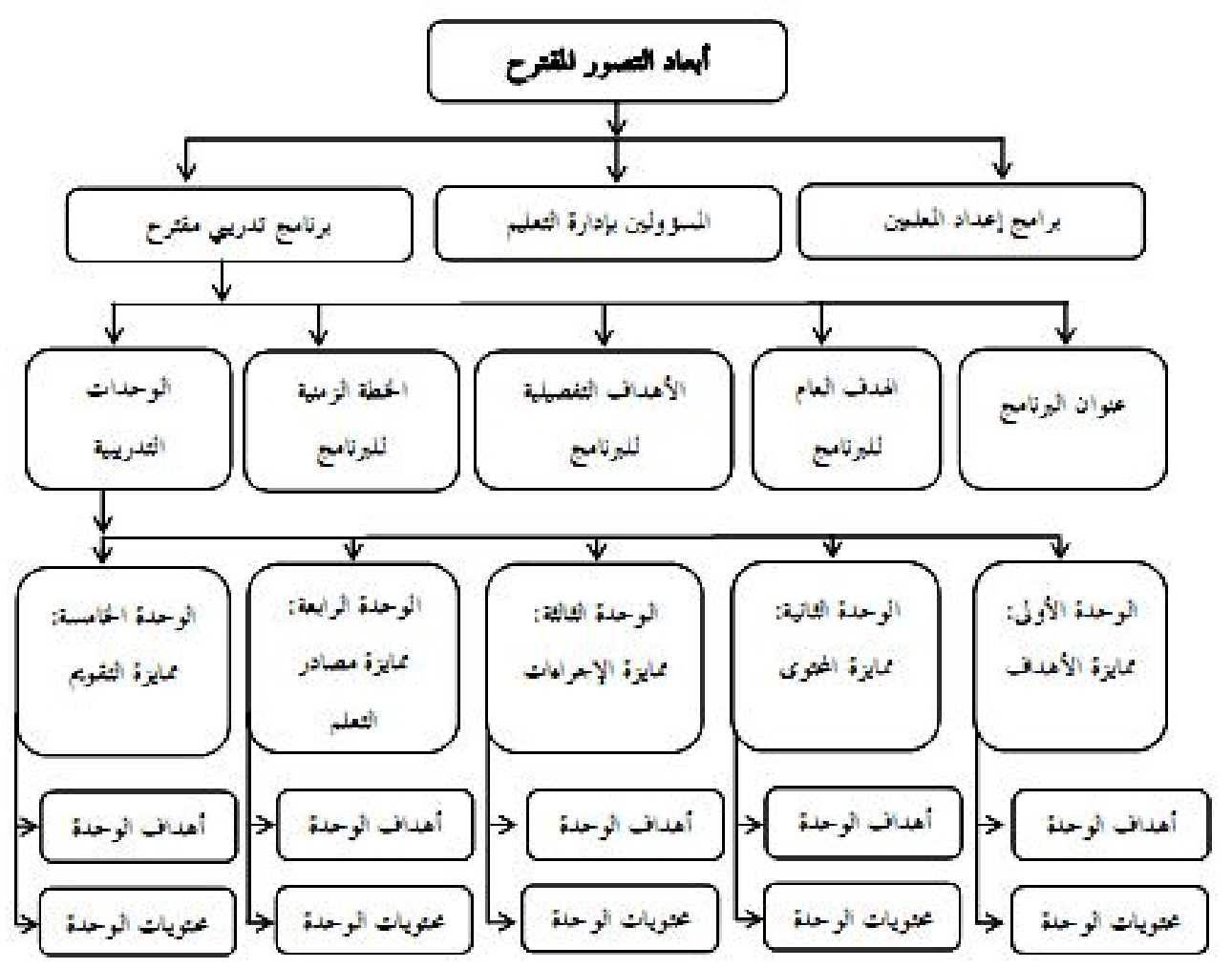

ه - الجهات المعنية بتطبيق التصور المقترح

ب- توفير الدعم المادي، و الفني اللازم؛

أ- كليات التربية في المملكة العربية لتنفيذ التصور المقترح. السعودية.

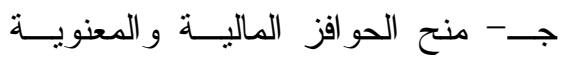

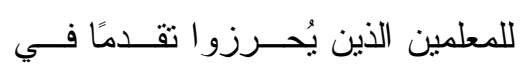
ب- وزارة التعليم في المملكة العربية

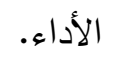
د- نشر التجارب الناجحة لمعلمي العلوم

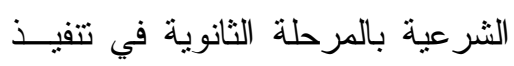

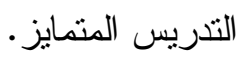

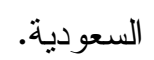
جـ- إدارة التعليم في محافظة عفيف. צ- آليات تنفيذ التصور المقترح أ- مو افقة إدارة التعليم في محافظة عفيف لهفيل على تتفيذ التصور المقترح. 


\section{- توصيات الدرّراسة:}

أ- ضرورة اهتمام القائمين علــى العمليـــة

التعليمية في محافظة عفيـــ بمعالجــة فئة جو انب القصور في أداء معلمي العلــوم

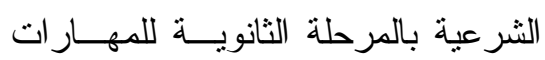

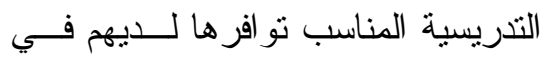

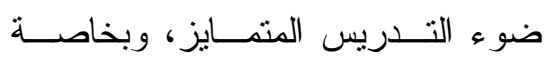

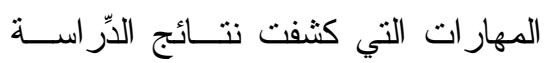

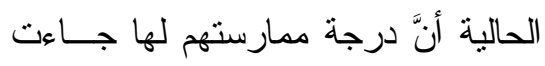

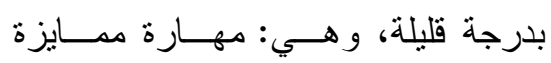
مصادر التعلم، ومهارة ممايزة التقويم. ب- العمل على تحديد المعوقات/الصعوبات التي تو اجه معلمــي العلــوم الــشرعية

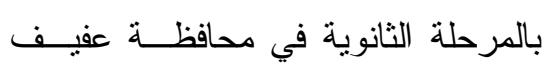

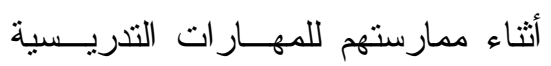
المناسب تو افر ها لــديهم فـــي ضــــو التدريس المتمايز، ومن ثم العمل علـى

\section{حلها.} جـ- عقد دور ات تدريبية لمعلمي العلــوم

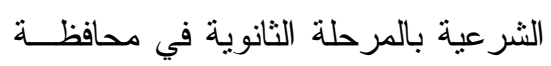

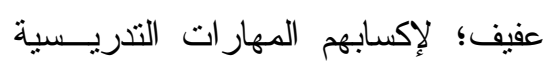

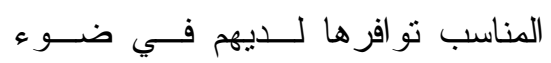
التدريس المتمايز، و العمل على نتميـــة هذه المهار ات لديهم.

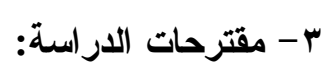

ويرى الباحــث أن تتفيــذ التـصور

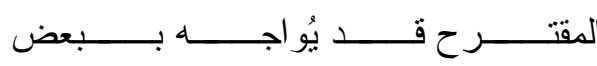
الصعوبات/المعوقات وبخاصة ما يتعلق منها

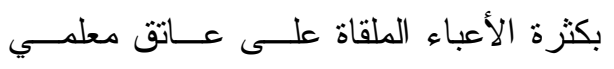

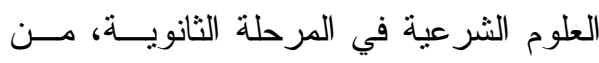
مهام تدريس ومهام إدارية وغير ها من المهام

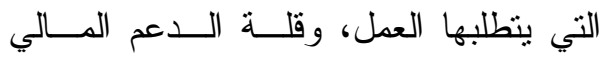

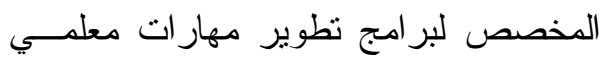
العلوم الشرعية. إلا أنَّ وجود مثل هذه الصعوبات من

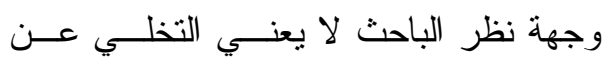

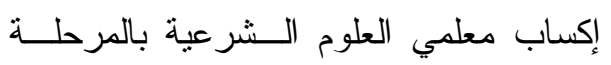

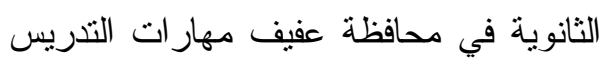

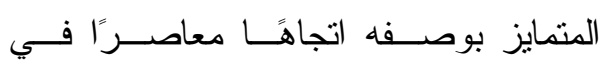

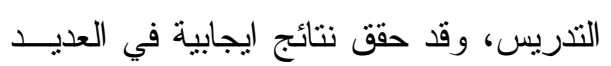

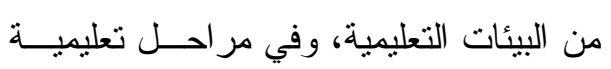
مختلفة. بل الأمر يتطلب العمل علــى تــذليل

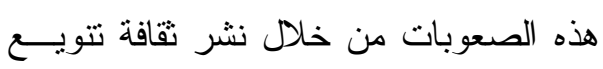

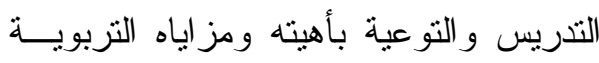

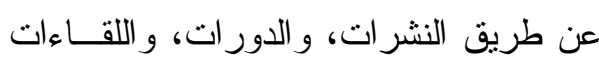
التربوية، وتوفير الدعم المالي اللازم؛ لتيسير

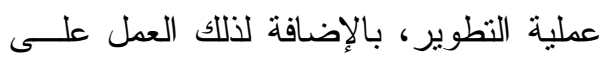

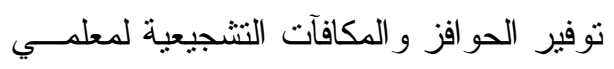

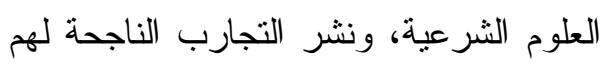

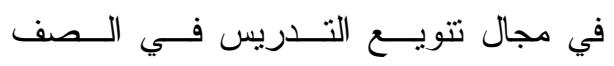

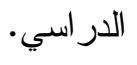




$$
\begin{aligned}
& \text { المهار ات الهجومية في كرة اليد. مجلة } \\
& \text { استكمالاً للجهود البحثيــة فـي هـــا }
\end{aligned}
$$

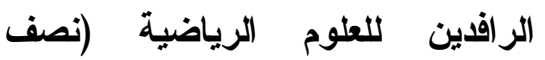

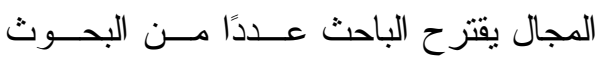

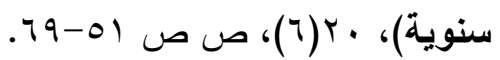

$$
\begin{aligned}
& \text { و الدِّر اسات في مجال الدّر اسة الحالية، ومنها: } \\
& \text { حسن، عمار فاضل.(T 1 •rم). أثز التعليم } \\
& \text { أ- تقويم الأداء التذريسي لدى معلمي العلوم } \\
& \text { المتمايز في تحصيل طلبة قسم التربية }
\end{aligned}
$$

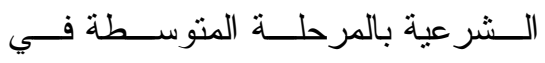

$$
\begin{aligned}
& \text { الفنية في مادة تاريخ الفن. مجلة ديالي، } \\
& \text { (V) ) ص ص • • (V) }
\end{aligned}
$$

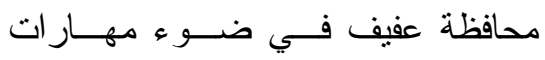

$$
\begin{aligned}
& \text { التدريس المتمايز } \\
& \text { الحليسي، معيض بن حسن بن معيض. }
\end{aligned}
$$

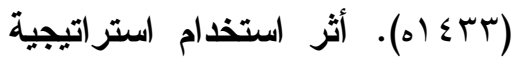

$$
\begin{aligned}
& \text { التعليم المتمايز على التحصيل الدراسي التي } \\
& \text { في مقرر اللغة الاجليزية لدى تلاميذ } \\
& \text { الصف السادس الابتائي. رسالة } \\
& \text { ماجستير، جامعة أم القرى، مكة } \\
& \text { المكرمة. } \\
& \text { الدوسري، حمزة. (با.•rم). التعليم } \\
& \text { المتمايز. موسوعة التعليم و التنريب. } \\
& \text { مسترجع من: goo.g1/KCA9h7 } \\
& \text { زايد، نبيل محمد. (10 • rم).الدور القيمي } \\
& \text { يغلف أدو ار أساتذة الجامعة في التدريس }
\end{aligned}
$$

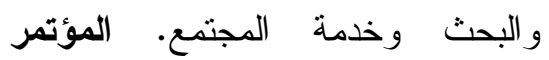

$$
\begin{aligned}
& \text { العلمي الدولي الأول للقياس والتقويم }
\end{aligned}
$$

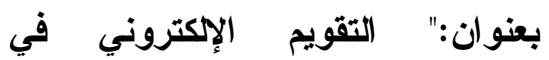

$$
\begin{aligned}
& \text { المؤسسات التعليمية (الو اقع - الفرص - بونئ }
\end{aligned}
$$

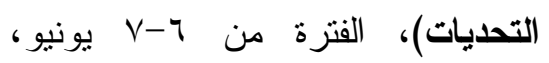

$$
\begin{aligned}
& \text { مركز القياس و التقويم، جامعة الزقازيق، } \\
& \text { مصر. } \\
& \text { ب- الصعوبات/المعوقــات التــي تو اجـهـ } \\
& \text { معلمي العلوم الثرعية بالمرحلة الثانوية } \\
& \text { في محافظة عفيف في ضوء التـدريس }
\end{aligned}
$$

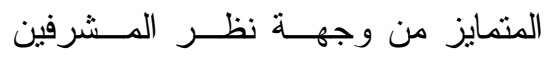

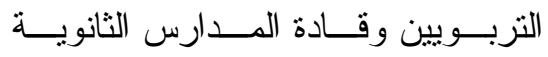

$$
\begin{aligned}
& \text { الحكومية. } \\
& \text { جـ- فاعلية برنامج تدريبي مقتــر ح قـائم }
\end{aligned}
$$

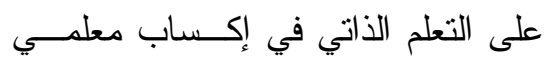

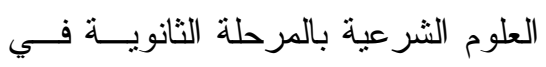

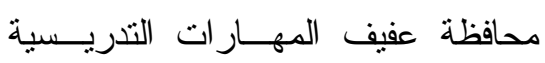

$$
\begin{aligned}
& \text { المناسب تو افرها لــديهم فــي ضــــو }
\end{aligned}
$$

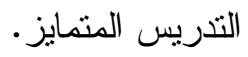

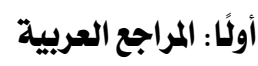

$$
\begin{aligned}
& \text { التعليم المتمايز في إكساب بعض }
\end{aligned}
$$




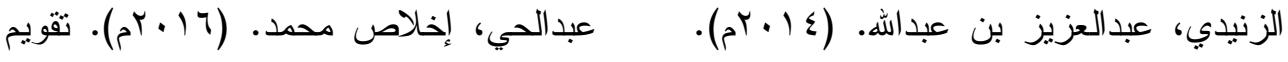

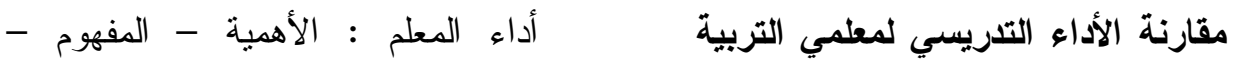

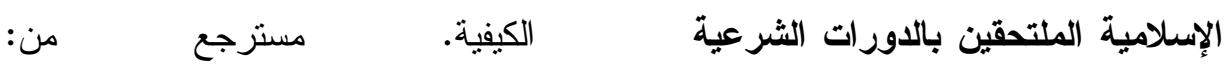

$$
\begin{aligned}
& \text { goo.gl/iCvpGR وغير الملتحقين في محافظة عنيزة. }
\end{aligned}
$$

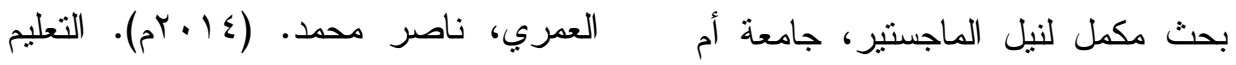

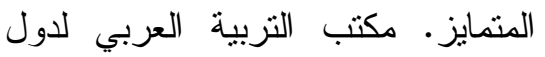

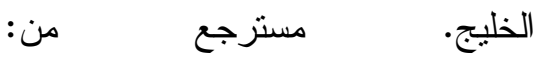

$$
\begin{aligned}
& \text { goo.g1/cLMtGb } \\
& \text { الغامدي، فريد بن علي. (rا •rم). مدى } \\
& \text { استجابة معلمي التزبية الإسلامية في } \\
& \text { المرحلة الابتدائية لاحتياجات جيع لإنيع }
\end{aligned}
$$

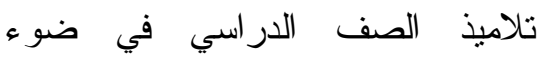

$$
\begin{aligned}
& \text { مهار ات التدريس المنمايز.مجلة كلية }
\end{aligned}
$$

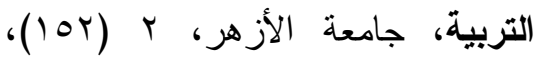

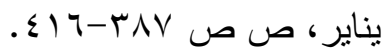

$$
\begin{aligned}
& \text { الكثكي، عمرو كمال، سعدالله، أيمن نبيه. } \\
& \text { (11) } \\
& \text { التعليم المتمايز وتتمية مهار ات التفكير } \\
& \text { لإعداد معلم الفن المستقبلى. المؤتمر } \\
& \text { السنوي (العربي السادس - الدولي } \\
& \text { الثالث)، تطوير برامج التعليم العالي التئي } \\
& \text { النوعي في مصر والوطن العربي في بطي } \\
& \text { ضوء متطلبات عصر المعرفة، الفترة } \\
& \text { من (سا-ــا أبريل)، كلية التربية }
\end{aligned}
$$

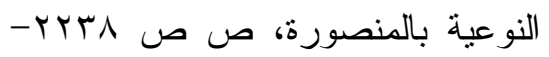

$$
\begin{aligned}
& \text {. TYNO }
\end{aligned}
$$

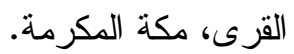

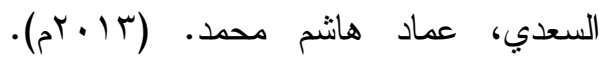

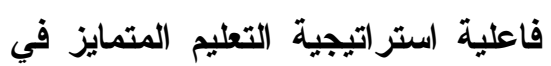

$$
\begin{aligned}
& \text { تحصيل طلاب الصف الرابع الأدبي في } \\
& \text { مادة الأبب والنصوص. رسالة } \\
& \text { ماجستير، جامعة ديالي، بعقوبة. } \\
& \text { السُليم، غالية بنت حدم بن سليمان. }
\end{aligned}
$$

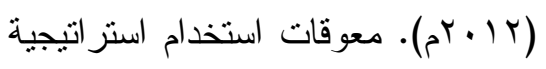

$$
\begin{aligned}
& \text { التعليم المتمايز في تدريس مقررات } \\
& \text { العلوم الثرعية في المرحلة الابتدائية } \\
& \text { من وجهة نظر المعلمات في مدينة } \\
& \text { الرياض. مجلة كلية التربية، جامعة }
\end{aligned}
$$

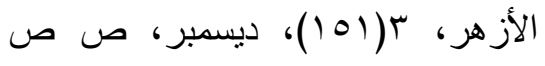

$$
\begin{aligned}
& \text {. ह|9-r人। }
\end{aligned}
$$

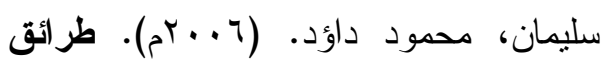

$$
\begin{aligned}
& \text { وأساليب التدريس المعاصرة. إربد: }
\end{aligned}
$$

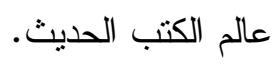

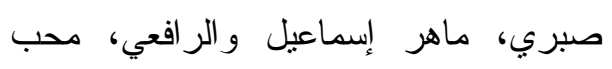

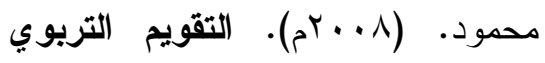

$$
\begin{aligned}
& \text { أسسه وإجراء(ته. الرياض: مكتبة }
\end{aligned}
$$

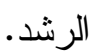


مجلة التربية العلمية، الجمعية المصرية

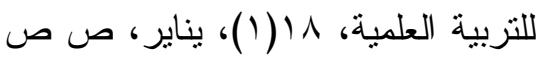

$. r q-1$

ثانيًا: المراجع الأجنبية

Good, Melinda.

(2006).

Differentiated Instruction:

Principles and Techniques for the Elementary Grades.

Submitted i

n Partial Fulfillment of the Requirements for the Degree Master of Science in Education .Retrieved from: https://eric.ed.gov/?id=ED4915 80

Kaddoura, Mahmoud.(2016).

Think Pair Share: A Teaching Learning Strategy to Enhance Students' Critical Thinking. Educational Research

Quarterly, 36 (4), Jun, PP3-24.

Koeze, Patricia.

Differentiated

(2007).

The Effect on Student

Achievement in an

Elementary School.. Master's

Theses and Doctoral

Dissertations. Eastern

Michigan

UniversityDigitalCommons@E

MU.
كوجل، كوثز بنت حسين وآخرون

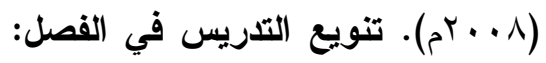

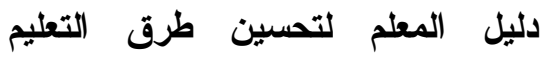

والتعلم في مدارس الوطن العربي.

بيروت: مكتب اليونسكو الإقليمي للتربية في الدول العربية.

لطف الله، نادية سمعان. (0. . ب م). أثنر

استخدام استراتيجية "فكر زاوج شارك" لأن

في التحصيل و التفكير الابتكاري ودافعية

الإنجاز لدى تلاميذ الصف الرابع

الابتدائي المعاقين بصريًا. مجلة التربية

العلمية، 1 (ץ)، سبتمبر، ص ص صلين

$.17 r-114$

محمد، أحمد قاسم وحسين، جميل أحمد.

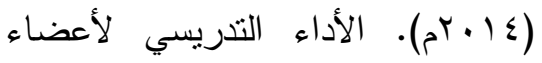

هيئة التدريس في سكول التزبية

الرياضية من وجهة نظر الطلبة في

جامعة دهوك. مجلة العلوم الإنساتية،

$$
\text { 0 } 0
$$

محد، حاتم مرسي. (10 • rم). فاعلية

مدخل التدريس المتمايز في تدريس

العلوم على تتمية المفاهيم العلية

و الاتجاه نحو العلوم لدى تلاميذ المرحلة

الابتدائية بالمملكة العربية السعودية. 